\title{
WestVirginiaUniversity
}

THE RESEARCH REPOSITORY @ WVU

Graduate Theses, Dissertations, and Problem Reports

1999

\section{Geologic controls on mass movement in the New River Gorge, West Virginia}

Jonathan William Frank Remo

West Virginia University

Follow this and additional works at: https://researchrepository.wvu.edu/etd

\section{Recommended Citation}

Remo, Jonathan William Frank, "Geologic controls on mass movement in the New River Gorge, West Virginia" (1999). Graduate Theses, Dissertations, and Problem Reports. 987.

https://researchrepository.wvu.edu/etd/987

This Thesis is protected by copyright and/or related rights. It has been brought to you by the The Research Repository @WVU with permission from the rights-holder(s). You are free to use this Thesis in any way that is permitted by the copyright and related rights legislation that applies to your use. For other uses you must obtain permission from the rights-holder(s) directly, unless additional rights are indicated by a Creative Commons license in the record and/ or on the work itself. This Thesis has been accepted for inclusion in WVU Graduate Theses, Dissertations, and Problem Reports collection by an authorized administrator of The Research Repository @ WVU. For more information, please contact researchrepository@mail.wvu.edu. 


\title{
GEOLOGIC CONTROLS ON MASS MOVEMENT IN THE NEW RIVER GORGE, WEST VIRGINIA.
}

\author{
Thesis \\ Submitted to the College of Arts and Sciences \\ of \\ West Virginia in Partial Fulfillment of the Requirements \\ for the \\ Degree of Master of Science
}

Submitted by

Jonathan W. F. Remo

Morgantown, West Virginia

1999

Department of Geology and Geography

Committee

Dr. J. Steven Kite (Chair)

Dr. Henry W. Rauch

Dr. Robert C. Shumaker

Key Words: Landslides, Rates of Mass Movement, Colluvium, New River Gorge, West Virginia 


\title{
Geologic Controls on Mass Movement in the New River Gorge, West Virginia.
}

\author{
Abstract \\ Jonathan W.F. Remo
}

Geologic factors, such as bedrock lithology, joints, lineaments, and attitude of bedding were analyzed and evaluated for influences on mass-movement in the New River Gorge. Mass-movement deposits were mapped at a 1:24,000 scale in three study areas within the gorge and a Geographic Information System was developed to analyze the affects of local bedrock geology on the deposits.

Analysis of bedrock lithology revealed that the greater the percentage of quartz sandstone within the gorge, the more area is covered by mass-movement deposits. This trend is related to the preservation potential of the deposits. Stress-release and tectonic joints affect mass movement in the gorge by providing planes of weakness for rocks to fail along, aiding development of hollows along the gorge walls, and controlling groundwater flow. Tectonic joints and lineaments have no direct affect with the orientation or location of mass-movement deposits in the gorge, however these features may indirectly influence the orientation and location of mass-movement deposits by controlling the trend of the New River.

The gorge also provides an excellent opportunity to assess present-day rates of mass-movement by calculating the volume of mass-movement deposits on abandoned road and railroad grades divided by the amount of time since abandonment. The calculated mass-movement rate for the three formations analyzed in this study varied between 36.02 and $71.60 \mathrm{~m} / \mathrm{ma}$. The mass-movement rate for the resistant cap rock is similar to the $36 \mathrm{~m} / \mathrm{ma}$ calculated by Dole and Stabler (1909) for the Southern 
Appalachians, and to Granger and other's (1997) $27.3 \pm 4.5 \mathrm{~m} / \mathrm{ma}$ Quaternary downcutting rate of the New River in southwestern Virginia.

The unexpected result of this study is that the regional denudation and downcutting rates are similar to the mass-movement denudation rates found on disturbed slopes of the gorge. It was expected that disturbed slopes in this study would have a significantly higher rate of denudation than the average denudation rate for the whole landscape. Human influence and climate are likely reason for the similarity of denudation rates based on historic sediment studies and mass-movement rates calculated in this study. 


\section{Table of Contents}

$\underline{\text { Page }}$

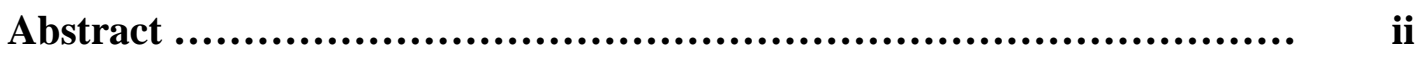

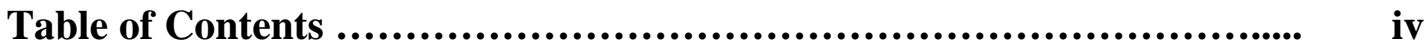

List of Figures ............................................................ vi

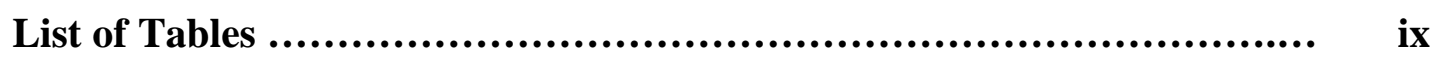

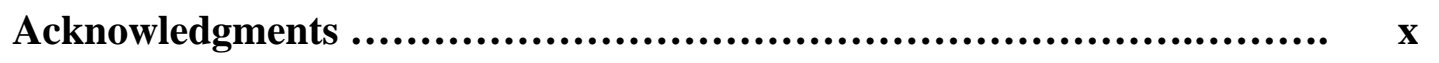

Chapter One: Lithologic and Structural Controls on Mass-movement in the New River Gorge, West Virginia................................ 1

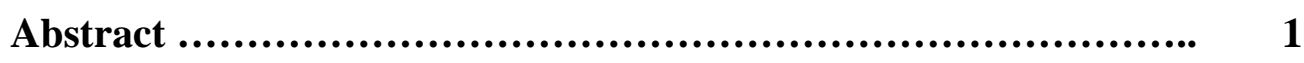

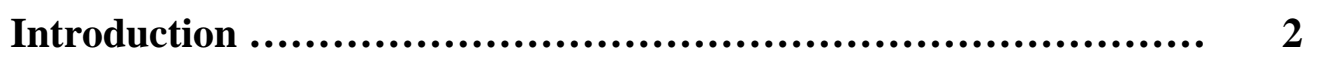

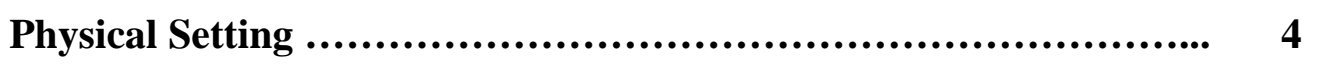

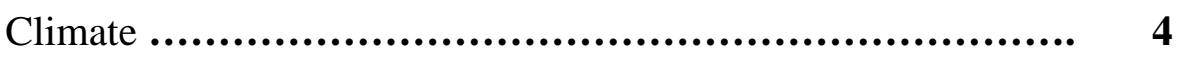

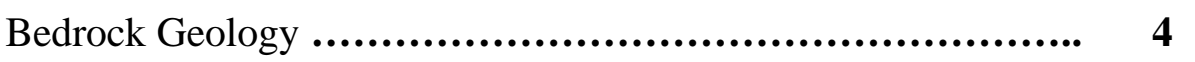

Structural Geology ................................................. 7

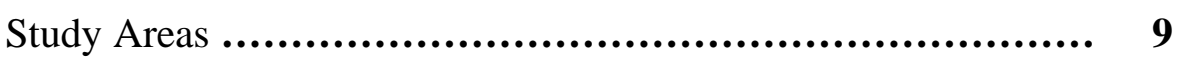

Soils of the New River Gorge............................... .13

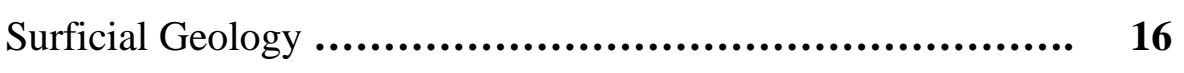

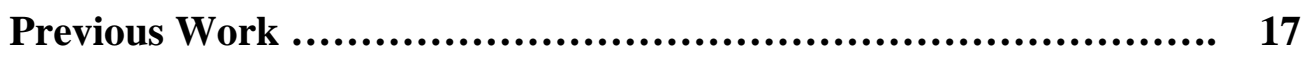

Methods ..................................................................... 20

Classification of Mass-movement ...................................... 21

Mass-movement Deposits .......................................... 23

Historic Debris Slide and Debris Flow Deposits ................ 23 
Mine Spoil and Mine Refuse Deposits

Rock Fall

29

Prehistoric Debris-flow Deposits

Prehistoric Debris-slide Deposits

32

Prehistoric Complex Deposits

Effects of Lithology on Mass-movement Deposits

Effect of Structural Geology on Mass-movement Deposits ..

Joints

Lineaments

Attitude of Bedding

Other Factors

67

Summary

References

Chapter Two: Modern Day Mass-movement Rates in the New

River Gorge, West Virginia....................................

76

Abstract

76

Introduction

Previous Work

Physical Setting

78

Methodology

82

Results

88

Discussion

References 
Appendix 1: Bedding parting and joint spacing data on the Nuttal Sandstone Members of the New River Formation.............

Appendix 2: Data on mass-movement deposits in the lower gorge

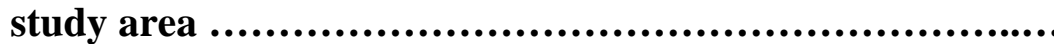

Appendix 3: Data on mass-movement deposits in the middle gorge

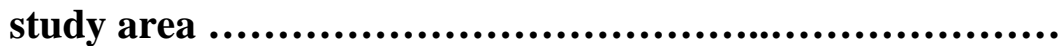

Appendix 4: Data on mass-movement deposits in the upper gorge

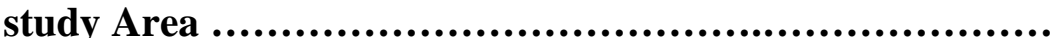

99

Appendix 5: Slope data for the three study areas

100

Appendix 6: Data for denudation rates along the railroad grade between Dunloup Creek and the town of Mindon .............

Appendix 7: Data for denudation rates along the railroad grade from Dunloup Creek Along the New River down stream $4.56 \mathrm{~km}$

Appendix 8: Data for denudation Rates along the Road Grade from Glade Creek $4.56 \mathrm{~km}$ upstream

Approval of the examining committee 


\section{List of Figures}

$\underline{\text { Figure }} \quad \underline{\text { Page }}$

1. Generalized stratigraphic column $\ldots . . . . . . . . . . . . . . . . . . . \quad 5$

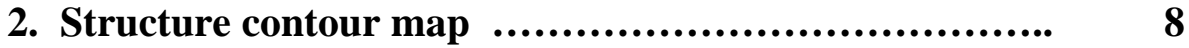

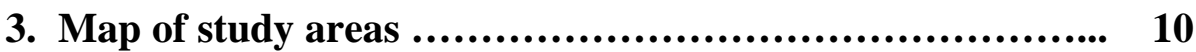

4. Geologic map of the upper gorge study area ............. 12

5. Geologic map of the middle gorge study area ............. 15

6. Geologic map of the lower gorge study area .............. 16

7. Map of mass-movement deposits in the lower gorge .... 24

8. Map of mass-movement deposits in the middle gorge ... 25

9. Map of mass-movement deposits in the upper gorge .... 26

10. Generalized geologic cross-section showing features of stress-release jointing .................................... 40

11. A X-Y plot showing the relationship between the total percentage of mass-movement deposits and total percentage of the area with a given aspect along joint trends.........................................

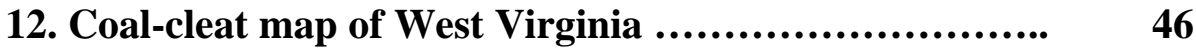

13. Rose diagrams showing the orientation of massmovement deposits in relation to orientation of coal cleats

14. Rose diagrams comparing coal-cleat orientations with the the trend of the New River ............................. 50

15. Map of LANDSAT lineaments in and around the gorge 52

16. A X-Y plot showing the relationship between the total percentage of mass-movement deposits and total percentage of the area with a given aspect along orthogonal coal-cleat trends 
17. Map of lineaments in the lower gorge study area ......... 56

18. Map of lineaments in the middle gorge study area ....... 57

19. Map of lineaments in the upper gorge study area ......... 58

20. Schematic diagram of caves found in the massive quartz cap rock of the lower and middle gorge study areas ...... 66

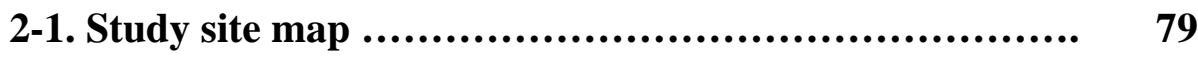

2-2. Generalized stratigraphic column ....................... 81

2-3. Map of Pocahontas Formation sampling section ......... 84

2-4. Map of Bluestone Formation sampling section ........... 85

2-5. Map of Hinton Formation sampling section ............. 86

2-6. Pictures of mass-movement deposits in sampling sections 87 


\section{List of Tables}

$\underline{\text { Table }}$

$\underline{\text { Page }}$

1. Slope, valley width, formation and lithology data for the

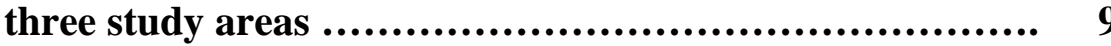

2. Results of mapping ........................................... 23

3. Percentage of sandstone found in gorge walls .............. 35

4. The data and calculations for joint trend analysis............ 42

5. The data and calculations for the coal-cleat trend analysis... 48

6. The data and calculations for the orthogonal coal-cleat analysis..................................................... 53

7. The data and calculations for the lineament analysis .........60

8. The data and calculations for the LANDSAT lineament Analysis.................................................. 63

9. A summary of the analysis between the relationship of mass-movement deposits and the New River meander bends ........................................................... 69

2-1. Results from the mass-movement denudation calculations. 88 


\section{Acknowledgments}

First and foremost, I would like to thank my parents, William and Gail for all the support and love they have given in all my life endeavors. They always believed in me even when I had doubts in myself.

I would like to present a special thanks to Dawn Moore my field partner in this study. First I also like to thank Dawn for here critical reviews of this manuscript.

Secondly, I greatly appreciate her help in dealing with the social aspects of southern West Virginia, to which I am not accustomed. Dawn and her significant other, Lee Newell, made my field and other experiences in the New River Gorge forever immortal in my memory.

I greatly appreciate the efforts of committee members Dr. Rauch and Dr. Shumaker for the insight and critical review of my thesis. I would also like to thank the Department of Geology and Geography at West Virginia University and Geological Society of America Southeast Section for partial funding of this study.

Last, but probably foremost, I would like to thank Dr. Kite for putting up with my writing style and for all his help and insight into my thesis and professional development. Thank you all for you help and support. 


\title{
Lithologic and Structural Controls on Mass Movement in the New River Gorge, West Virginia.
}

\begin{abstract}
A study was undertaken in the summer of 1998, to analyze the geologic controls on mass movement in the New River Gorge, West Virginia. Geologic factors, such as bedrock lithology, joints, lineaments, and attitude of bedding were analyzed and evaluated. Mass-movement deposits were mapped at a 1:24,000 scale in three study areas within the gorge. These study areas were selected based on bedrock lithology and structural geology.

One hundred seventy seven mappable mass-movement deposits were identified within the three study areas. The age of the deposits were classified as either prehistoric or historic. Most historic mass movement in the New River Gorge is related to human activities, such as undercut slopes and altered drainage. Historic mass-movement deposits were not analyzed because they are related to human activities and not the result of natural processes.

Bedrock lithology affects the size of materials in mass-movement deposits. Thick quartz sandstones produce blocks up to $40 \mathrm{~m}$ in long axis and up to $16 \mathrm{~m}$ in intermediate axis. Feldspathic siltstone and sandstone rarely produce boulders larger than $1.5 \mathrm{~m}$ in long and intermediate axis. Analysis of bedrock lithology revealed that the greater the percentage of quartz sandstone within the gorge, the more area is covered by massmovement deposits. This trend is related to the preservation potential of the deposits. Mass-movement deposits derived from weaker lithologies generally consist of finer material that is easily removed from the landscape by fluvial processes.
\end{abstract}


Stress-release and tectonic joints affect mass movement in the gorge by providing planes of weakness for rocks to fail along, aiding development of hollows along the gorge walls, and controlling ground-water flow. Tectonic joints and lineaments have no direct correlation with the orientation or location of mass-movement deposits in the gorge however these features may indirectly influence the orientation and location of massmovement deposits by controlling the trend of the New River.

The New River is the most influential factor affecting the location and orientation of mass-movement deposits. There are more mass-movement deposits on the outside of bends because of undercutting of the slopes by the New River. The large volume of prehistoric mass-movement deposits and the inability of the modern-day New River to remove these deposits suggest they are relict landforms formed under different climatic conditions. The significant difference in size between historic and prehistoric massmovement deposits suggests the prehistoric deposits are related to enhanced weathering and colluviation under climatic conditions associated with one or more of the Pleistocene glaciations.

\section{Introduction}

The New River has sculpted a spectacular gorge through the Appalachian Plateau of south-central West Virginia. The geologic history of the New River Gorge has produced one of the deepest and most scenic gorges in the eastern United States, earning it the unofficial title of "Grand Canyon of the East". Most of the gorge lies within the New River Gorge National River, which provides numerous recreational and outdoor opportunities and attracts millions of visitors each year. 
The New River Gorge is situated within the deeply dissected landscape of the Appalachian Plateau. Most slope failures in the Appalachian Plateau occur in areas underlain by flat-lying, cyclothemic rocks, of Pennsylvanian to Permian age. Most slope failures in the Appalachian Plateau occur in colluvium or fined-grained rocks (Jacobson and Pomeroy, 1987). Modern slope failures in the Appalachian Plateau of West Virginia are commonly slow-moving earth flows and slumps (Lessing and Erwin, 1977). Debris slides and debris flows are more common in southwestern and south-central West Virginia, including the New River Gorge, due to steeper slopes and coarser, moreresistant bedrock (Outerbridge, 1986).

Historic mass-wasting events in the Appalachian Plateau are highly dependent on frequency of meteorological events that trigger slope failures by increasing pore-water pressures to failure conditions. These triggering events are the result of a culmination of factors, such as precipitation, evapotranspiration, and runoff (Jacobson and Pomeroy, 1987). Meteorological events often trigger mass movements, but there are numerous determinants that effect the location, failure mechanism, frequency, and size of slope failures. These determinants include aspect, slope, climate, hydrology, soil type, and geology. Two important determinants for failure mechanism, size, location, and rates of mass movement are bedrock lithology and structural geology (Briggs and others, 1975; Dolan and others, 1978; Pomeroy, 1982; Pomeroy and Thomas, 1985; Outerbridge, 1986; and Jacobson and Pomeroy, 1987).

Webb and others (1993) and Griffiths and others (1997) have documented the importance of stratigraphic position, lithology and mineralogy of bedrock to the frequency of historic debris flows in the Grand Canyon. Dolan and others (1978) have 
documented the effect of geologic structures, such as faults, on the formation of debrisflow fans in the Grand Canyon. This study attempts to gain a better understanding of the lithologic and structural controls influencing mass movement in the New River Gorge.

\section{Climate}

The New River Gorge has a humid continental climate. Rainfall in the lower and middle gorge study areas averages between 114 and $117 \mathrm{~cm} / \mathrm{y}$ annually (Gorman and Espy, 1975). The upper gorge study area averages between 89 and $102 \mathrm{~cm} / \mathrm{y}$ annually (Sponaugle and others, 1984). Generally, there is no large-scale spring melting of a seasonally accumulated snow pack because a thawing period usually follows each snowstorm. Thunderstorms occur an average of 45 days a year, usually in the months of June and July. Flash flooding on smaller watersheds is frequent after heavy rainfall from intense connective thunderstorms, large-area cyclonic and frontal storms (Gorman and Espy, 1975; Sponaugle and others, 1984).

\section{Bedrock Geology}

The New River Gorge is underlain by five geologic formations (figure 1). The oldest is the Upper Mississippian Hinton Formation. The Hinton Formation is 290 to 350 m thick and composed primarily of calcareous shale and siltstone, with lesser amounts of limestone and sandstone. The most resistant member of the Hinton is the $30 \mathrm{~m}$ thick Stony Gap Sandstone, which is composed largely of quartz. The Stony Gap Sandstone forms Sandstone Falls and is a major cliff former.

The Hinton is unconformably overlain by the Upper Mississippian Bluestone Formation, which consists mainly of nonresistant shale, siltstone, and limestone with thin sandstone beds. The Bluestone averages approximately $200 \mathrm{~m}$ thick. The only resistant 


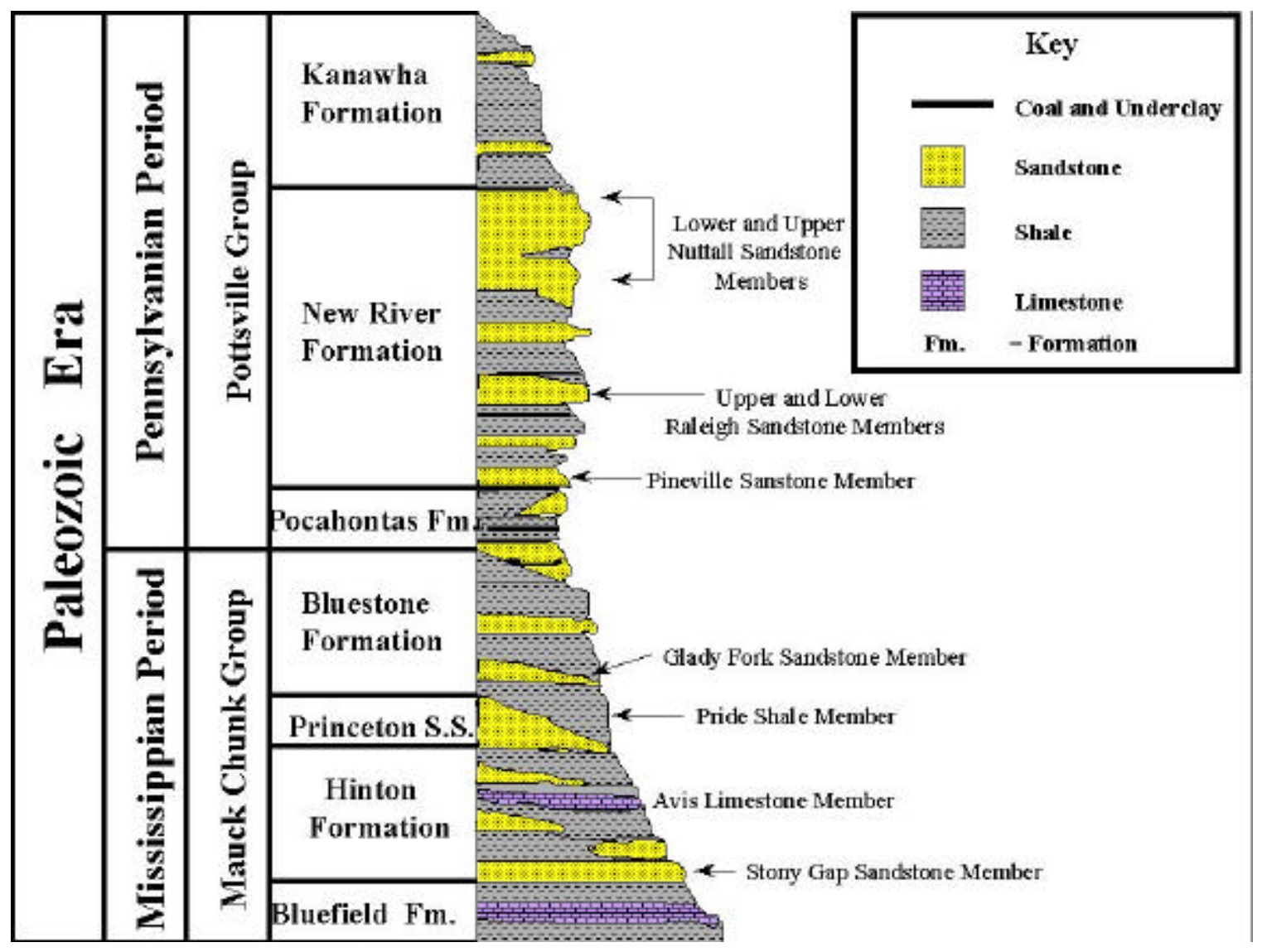

Figure 1: Generalized columnar section of bedrock exposed in the New River Gorge modified from Englund and others (1982). (Not to scale.) 
member is the Glady Fork Sandstone, which ranges in composition from silty ripplebedded sandstone to coarse conglomeratic sandstone (Englund and others, 1977; Englund and others, 1982).

The Lower Pennsylvanian Pocahontas Formation lies above the Bluestone Formation. The Pocahontas Formation consists of $70 \%$ sandstone, $28 \%$ shale, $2 \%$ coal and underclay. The Pocahontas Formation has a maximum thickness of $130 \mathrm{~m}$ in the southeastern part of the gorge, but thins to the northwest and pinches out in the Gauley Bridge Quadrangle (Englund and others, 1977; Englund and others, 1982).

The Lower Pennsylvanian New River Formation unconformably overlies the Pocahontas Formation. The New River Formation varies in thickness from $305 \mathrm{~m}$ thick in the Southeast to about $215 \mathrm{~m}$ in the northwestern part of the gorge (Englund and others, 1977; Englund and others, 1982). The New River Formation is comprised of sandstone, siltstone, shale, coal and underclay. The New River Formation is lithologically similar in composition to the Pocahontas, except for thicker and more widespread sequences of conglomeratic quartz sandstone. The resistant members of the New River Formation are the Upper and Lower Nuttall and Upper and Lower Raleigh sandstones. These units become less discernible to the southeast, because the Upper and Lower Nuttall and Upper and Lower Raleigh Sandstones become less resistant, due to an increase in mica and feldspar content (Englund and others, 1977; Englund and others, 1982).

The Kanawha Formation occurs primarily in the northern part of the gorge. It is approximately $90 \mathrm{~m}$ thick and lies conformably over the New River Formation. The 
Kanawha is composed $65 \%$ of nonresistant shale and siltstone. Approximately $33 \%$ of the formation is sandstone, which is less quartzose than sandstone of the New River Formation, thus making it less resistant to weathering. The other $2 \%$ of the formation is coal and underclay (Englund and others, 1977). Overall, the New River Formation is by far the most resistant unit in the New River Gorge. The Pocahontas Formation is considered intermediate in resistance, whereas the Hinton, Bluestone, and Kanawha formations are relatively non-resistant units.

\section{Structural Geology}

In general, the structural complexity increases southeastwardly where the New River is in closer proximity to the Valley and Ridge physiographic province. Strata in the northwestern part of the gorge, specifically the Fayetteville and Prince quadrangles, have a regional dip of less than $2^{\circ}$ to the northwest. In the Thurmond, Prince, Meadow Creek, and Hinton quadrangles, the bedrock can locally increases dip up to $5^{\circ}$ due to minor folding found in these areas (figure 2).

Faulting in the New River Gorge consists of a few, small normal faults that do not show significant displacement (Englund and others, 1977; Englund and others, 1982). Unlike faults, numerous lineaments occur in the New River Gorge. Approximately 21 LANDSAT lineaments occur in the three study areas (Reynolds, 1979). Lineaments were also mapped for analysis in this study from USGS 7.5-minute quadrangles; 125 lineaments are within or in contact with the three study areas. Generally, joints are not well expressed in outcrops in the gorge. Orientations of coal cleats, face cleats, measured from outcrop, cores, and mines in the New River Gorge region suggest joint trends of $010^{\circ}$ to $020^{\circ}, 070^{\circ}$ to $090^{\circ}, 305^{\circ}$ to $315^{\circ}$, and $320^{\circ}$ to $325^{\circ}$ (Kulander and Dean, 1993 ). 


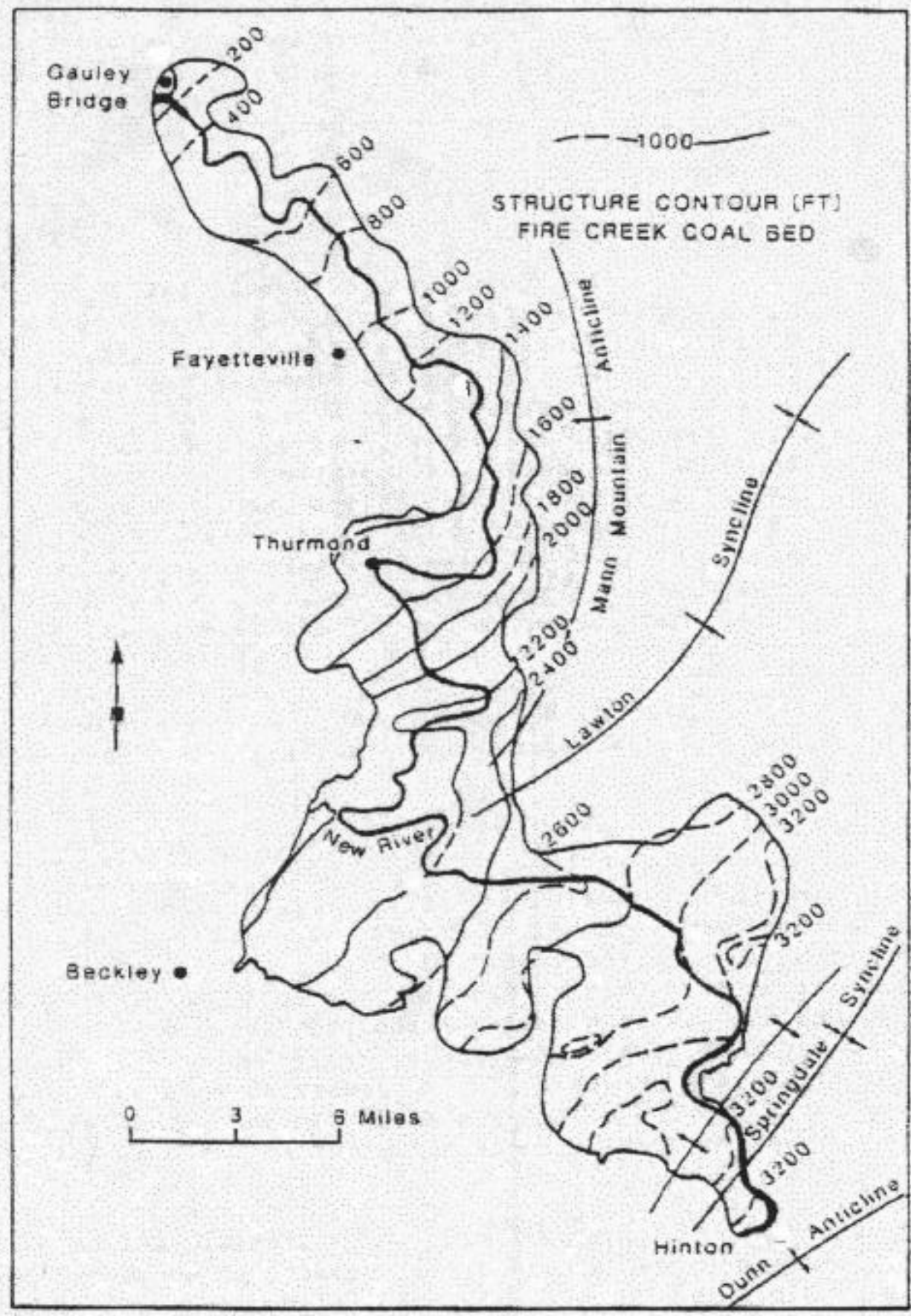

Figure 2: Structure contour map of the Fire Creek Coal in the New River Gorge. Map is from Englund and others (1982). 
Joint trends obtained from bedrock outcrops in the New River Gorge region show orientations of $005^{\circ}, 010^{\circ}, 025^{\circ}, 030^{\circ}, 060^{\circ}, 065^{\circ}, 070^{\circ}, 75^{\circ}, 285^{\circ}, 330^{\circ}, 340^{\circ}$, and $345^{\circ}$ (Colton and others, 1976).

\section{Study Areas}

The three areas chosen for this study occur along the New River between Hinton and Fayette Station, West Virginia (figure 3). These study areas are labeled according to their location within National Park Service (NPS) planning units. The upper gorge study area was selected for the structural setting and predominately weak bedrock lithologies. The upper gorge starts at the park's boundary just north of Hinton in the Hinton Quadrangle, and extends to Sandstone Falls, in the Meadow Creek Quadrangle (figure 3). Private property limits access to the gorge down stream from Sandstone Falls.

The upper gorge study area is characterized by shale-dominated valley walls, which are less steep and produce a wider valley floor compared to the other study areas (table 1). The bedrock in the upper gorge consists mostly of shale and feldspathic sandstone from the Bluestone and Hinton formations (figure 4). The attitude of bedding in the upper gorge varies from less than $2^{\circ}$ up to $5^{\circ}$ due to the influence of the Dunn anticline, the Springdale syncline, and adjacent unnamed folds (figure 2) (Englund and others, 1977; Englund and others, 1982).

The middle gorge study area extends from Glade Creek to Plateau, which are both in the Prince Quadrangle (figure 3). The middle gorge was selected because of the New River transects through the major geologic formations and the structural setting. The boundary of the middle gorge was selected based of access to the gorge. 


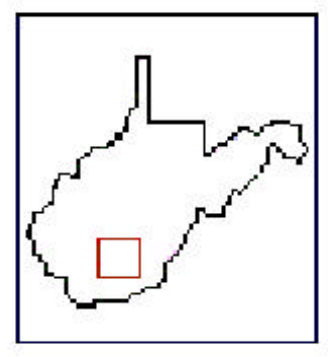

Quadrangles

Fay Fayetteville Quadrangle

Thu Thurmond Quadrangle

Pri Prince Quadranlge

Mea Meadow Creek Quadranlge

Hin Hinton Quadranlge

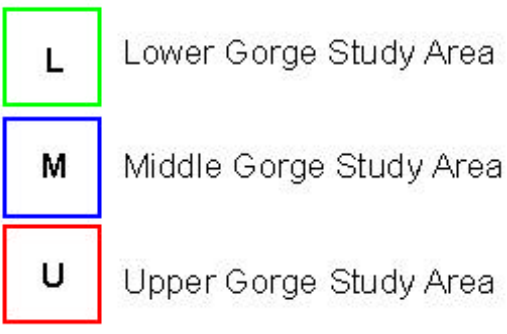

N 374500
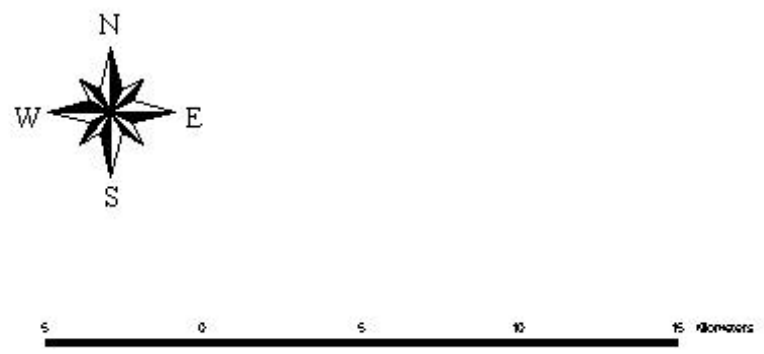

N 380730

W 810000

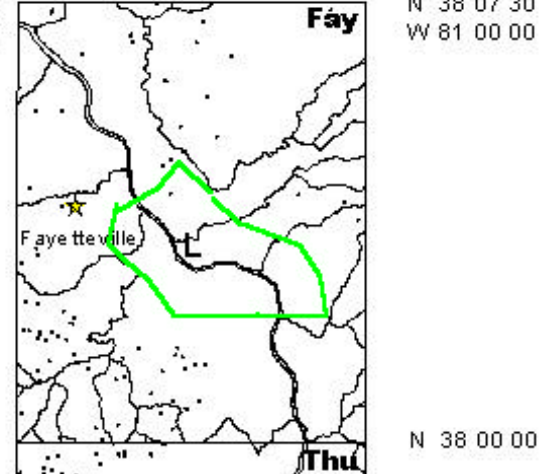

N 375230 W 805230

Figure 3: Map of study areas. 


\begin{tabular}{|l|c|c|c|}
\hline \multicolumn{1}{|c|}{ Study Area } & Upper Gorge & Middle Gorge & Lower Gorge \\
\hline Slope of Valley Walls & $15^{\circ}$ to $35^{\circ}$ & $20^{\circ}$ to $45^{\circ}$ & $25^{\circ}$ to $50^{\circ}$ \\
\hline Mean Width of Valley & $400 \mathrm{~m}$ & $240 \mathrm{~m}$ & $100 \mathrm{~m}$ \\
\hline \multicolumn{3}{|l|}{} \\
\hline New River Formation & $0 \%$ & $37 \%$ & $76 \%$ \\
\hline Pocahontas Formation & $12 \%$ & $22 \%$ & $20 \%$ \\
\hline Bluestone Formation & $35 \%$ & $30 \%$ & $4 \%$ \\
\hline Hinton Formation & $53 \%$ & $11 \%$ & $0 \%$ \\
\hline \multicolumn{3}{|l|}{} \\
\hline Sandstone & $18 \%$ & $42 \%$ & $48 \%$ \\
\hline Shale & $46 \%$ & $19 \%$ & $19 \%$ \\
\hline Limestone & $6 \%$ & $0 \%$ & $0 \%$ \\
\hline Shale with Interbedded S.S. & $0 \%$ & $11 \%$ & $0 \%$ \\
\hline Limey Sandstone & $4 \%$ & $0 \%$ & $0 \%$ \\
\hline S.S. Interbedded with Shale & $3 \%$ & $11 \%$ & $11 \%$ \\
\hline Concealed Section & $0 \%$ & $16 \%$ & $25 \%$ \\
\hline Coal and Fire Clay & $0 \%$ & $2 \%$ & $1 \%$ \\
\hline
\end{tabular}

Table 1: Slope, valley width, formation, and lithology data for the three study areas. Lithologic information was calculated from measured sections and well logs from Dyar (1957), Krebs and Teets (1916), and Hennen and others (1919). 


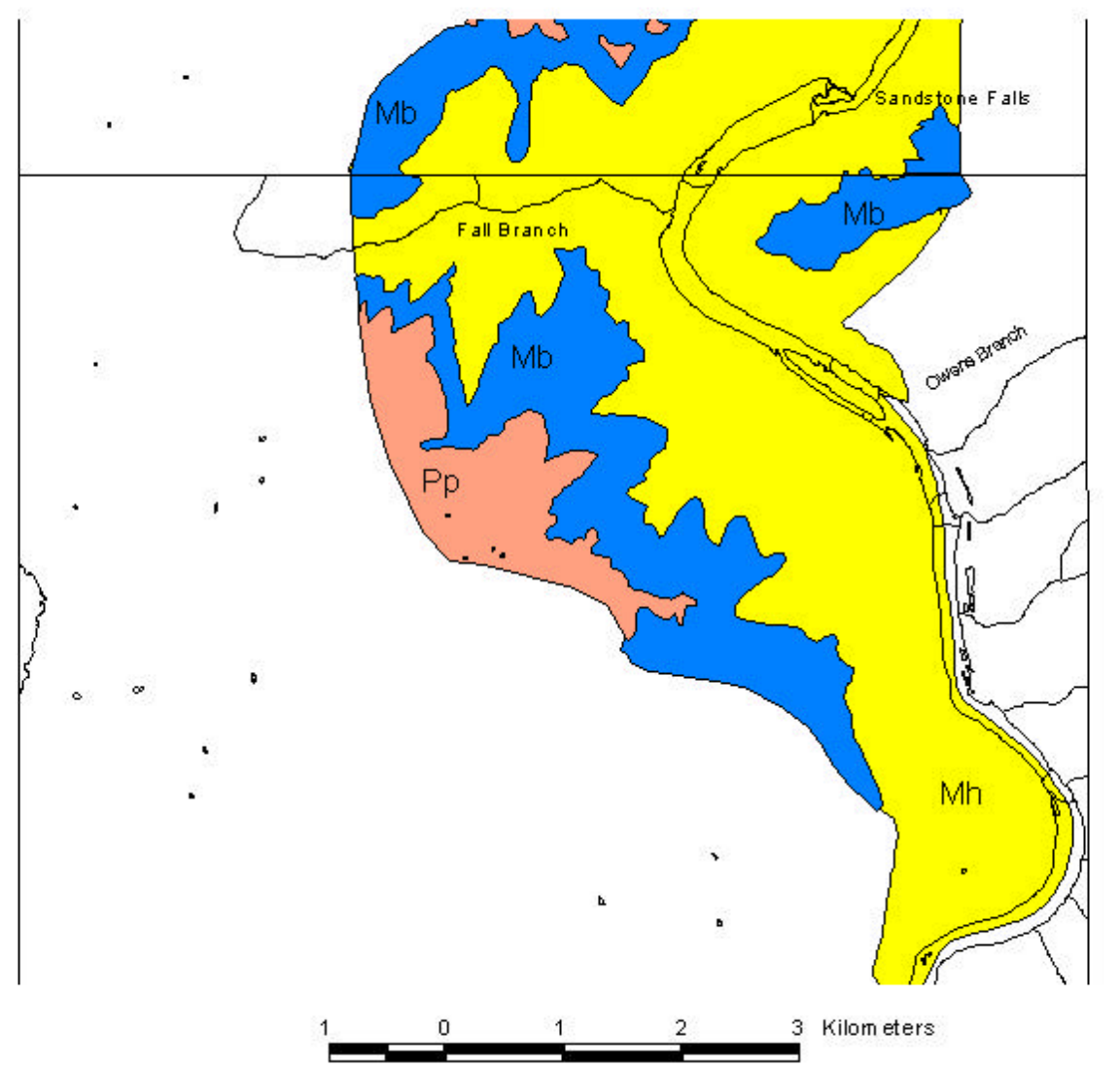

Explanation
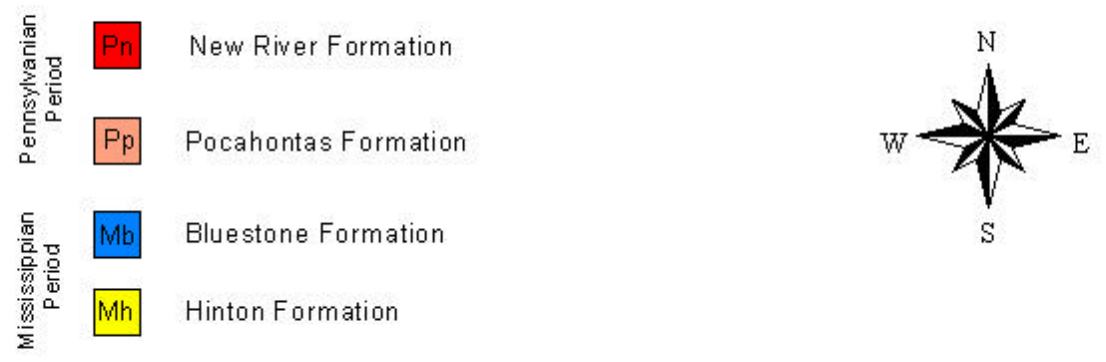

Figure 4: Geologic Map of the upper gorge study area, modified from Englund and others, (1977). See figure 3 for location. 
The middle gorge study area has steeper valley walls and a narrower valley floor than the upper gorge study area (table1). The middle gorge consists of a mixture of this New River, Pocahontas, Bluestone and Hinton formations with most of the section consisting of New River and Bluestone formations (figure 5). The lithology of the middle gorge consists of sandstone with lesser amounts of shale (table 1). The quartz content of the sandstones in the middle gorge is significantly greater than the upper gorge. The dip in this study area is generally less than $2^{\circ}$ to the northwest (figure 3 ) (Englund and others, 1977; Englund and others, 1982).

The lower gorge study area extends from Keeney Creek to Fayette Station in the Fayetteville Quadrangle (figure 6). This study area was primarily selected because of the New River's transect through the resistant lithologies of the New River Formation. The extent of the lower gorge was based on access to this section of the gorge. The lower gorge study area is the steepest and narrowest part of the New River Gorge (table 1). The lithology of the bedrock in the lower gorge consists of sandstone with lesser amounts of shale (table 1). The sandstones in the lower gorge are more quartzose and thicker than the middle gorge. Regional dip in this part of the gorge is generally less than $2^{\circ}$ to the northwest (figure 3) (Englund and others, 1977; Englund and others, 1982).

\section{Soils of the New River Gorge}

Soils in the upper gorge study area occur in the Calvin high base subtratum-BerkGilipin association, the Mononghela-Kanawha-Chagrin association and the Lily-GilipinErnest association. The Calvin high base subtratum-Berk-Gilipin association consists of moderately steep sloping to strongly sloping moderately well drained lime-influenced and acid soils on the uplands. Monongahela-Kanawha-Chagrin associations is composed of 


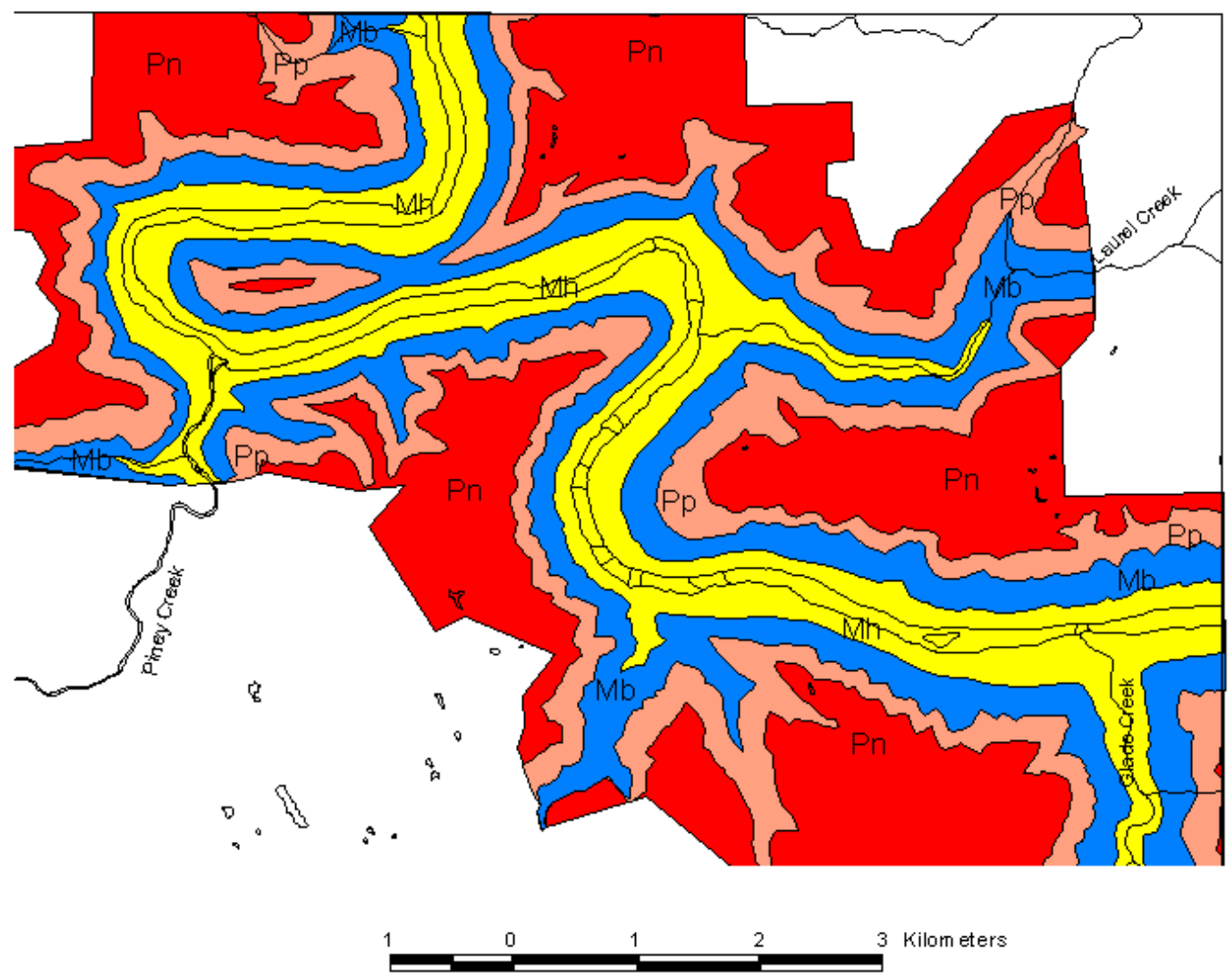

Explanation
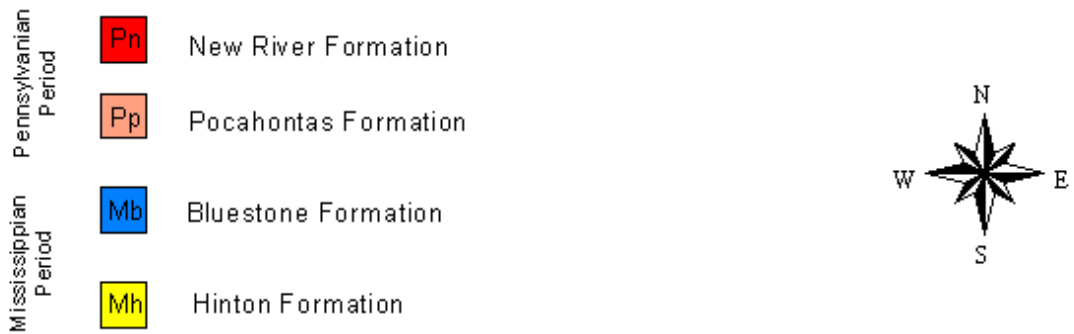

Figure 5: Geologic map for the middle gorge study area, modified from Englund and others, (1977). See figure 3 for location. 


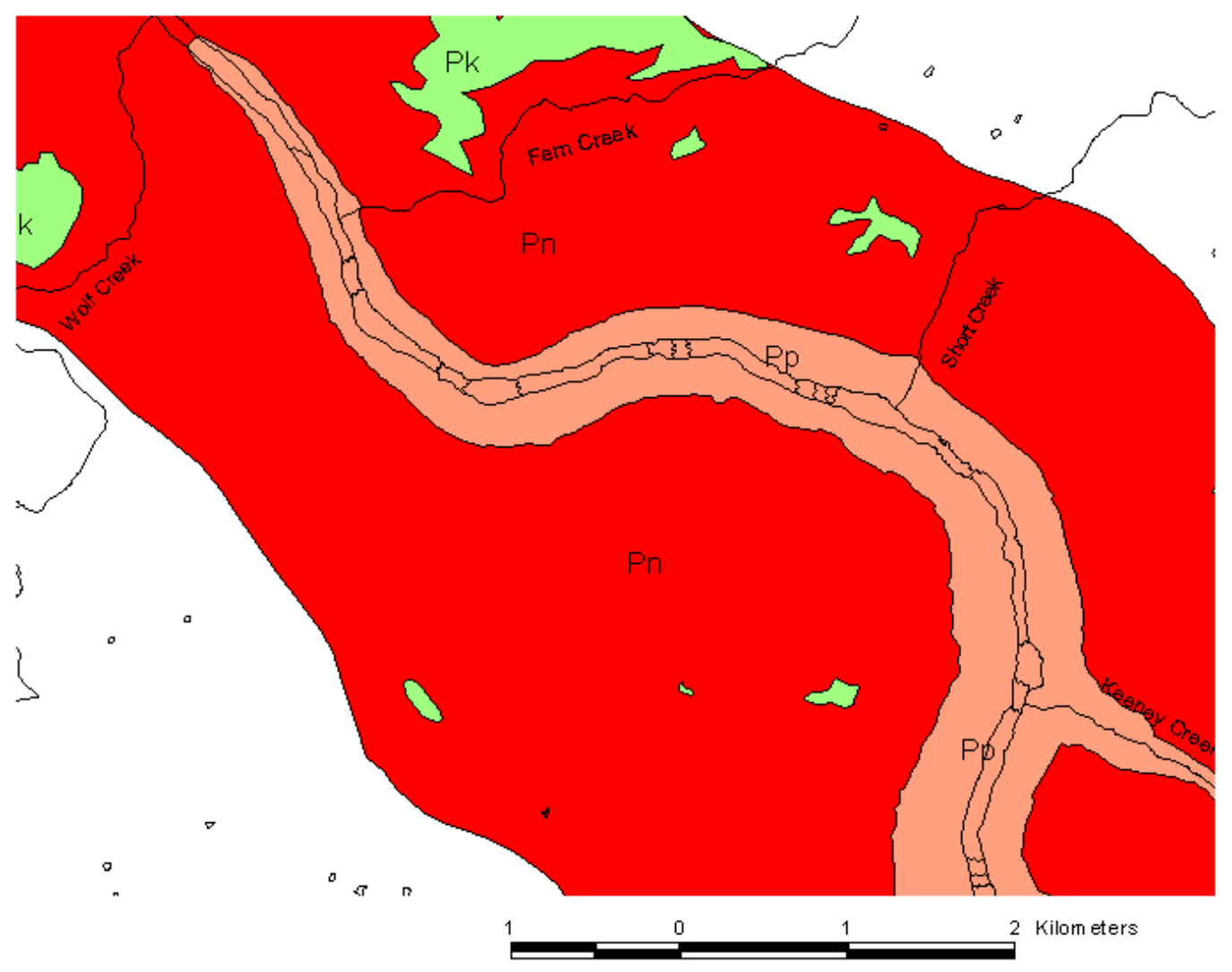

\section{Explanation}
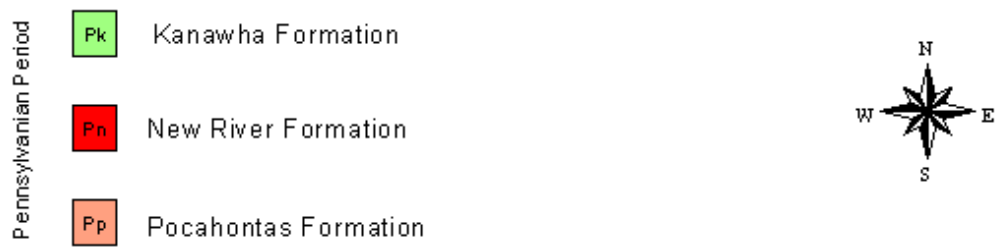

Figure 6: Geologic map for the lower gorge study area, modified from Englund and others (1977). See figure 3 for location. 
deep, nearly level to strongly sloping, moderately to well drained, acid and limeinfluenced soils found on the high and low floodplains. The Lily-Gilpin-Ernest association is made up of moderate to deep, gently sloping to very steep, well drained, acidic soils found on the uplands and foot slopes (Sponaugle and others, 1984).

Soils in the middle and lower gorge study area consist of the Steep RocklandDekalb-Gilpin association. Rough broken cliffs, upland rock outcrops, and moderately deep, well-drained, moderately coarse textured, very steep soils characterize this association. Soils on the lower gorge rim are channery, silt loam to sandy, silt-loam. Soils on the gorge slopes consist of steep rock land to very stony-silt loam. Mine soils and mine spoil materials occur along strip-mine benches and near deep-mine entrances (Gorman and Espy, 1975).

\section{Surficial Geology}

Surficial deposits overlie most of the bedrock in the New River Gorge. These deposits include alluvium and colluvium on the lower valley slopes of the New River and its tributaries (Englund and others, 1977). Fans occur at the mouths of most tributaries to the New River. The tributary fans in the upper gorge are generally fluvial in origin, but tributary fans in the middle and lower gorge generally have complex origins resulting from both fluvial and colluvial processes. The extent and size of the New River floodplains, terraces, mid-channel bars, and islands diminish as the New River Formation becomes closer to river level (Mills, 1990).

Many large colluvial deposits occur in the gorge. These deposits are derived from such mass-wasting processes as debris slides, debris flows, rock falls, rock topples, creep, 
and slumps. Most of the large colluvial landforms are prehistoric in age. Prehistoric colluvial landforms tend to be difficult to recognize due to their large size and the dense vegetation cover. Modern mass-movement landforms tend to be significantly smaller and related to human activity (Davies and Ohlmacher, 1977).

Talus occurs throughout the gorge below the resistant quartz sandstone cliffs. These talus accumulations are generally well vegetated, suggesting little new material is being added to these deposits. The lack of new material added to the talus suggests they may be the result of different climatic conditions. These talus piles may be the result of enhanced mechanical weathering and colluviation during one or more of the Pleistocene glacial periods.

\section{Previous Work}

Only two published works have focussed on mass movement in the New River Gorge. One is a landslide map by Davies and Ohlmacher (1977), which is a part of a USGS Open-File Report by Englund and others (1977). The Davies and Ohlmacher landslide map is a 1:50,000-scale map depicting recent slides, older slides, debris avalanches, and rock falls; it provides a short discussion of mass movements in the gorge. Davies and Ohlmacher stated that only a few slides have been active in historical times including two slides near Thrumond, which are 1.6 and $3.2 \mathrm{~km}$ wide. These two slides developed in deposits of weathered sandstone mixed with unsorted clay, sand, and fragments of vegetation. These deposits are up to $10 \mathrm{~m}$ thick and occur on slopes of $30^{\circ}$ to $45^{\circ}$. Davies and Ohlmacher also noted small slides in areas affected by mining. The second classification discussed by Davies and Ohlmacher is "older slides". Older slides are debris slides that have no historical record of movement. Most of the 
older slides occur along the valley walls between Meadow Creek and Stonecliff. These older slides are quite large, up to $3.9 \mathrm{~km}$ wide. They extend to $1.3 \mathrm{~km}$ up slope, and are up to $30 \mathrm{~m}$ deep. These older slides incorporate residual materials and do not involve bedrock. The lower surfaces of these slides are hummocky, with low rounded ridges transverse to the slide. Upper portions of these slides have long, narrow parallel lobes, generally $10 \mathrm{~m}$ to $30 \mathrm{~m}$ wide, trending down slope, which merge in lower parts of the slide. The valley walls in the slide area are recessed, forming shallow, steep-sided amphitheaters (Davies and Ohlmacher, 1977).

Davies and Ohlmacher use the term "debris avalanches" for mass movements that are more properly called debris flows or debris slides. A skim zone distinguishes a true debris avalanche from other types of rapid mass movement. Skim zones occur when the main body of the avalanche looses contact with the underlying slope and leaves the soil relatively undisturbed (Orme, 1987). The lack of evidence for skim zones suggests the term "debris avalanches" is inappropriate in the New River Gorge.

Several tracks of prehistoric debris flows or debris slides occur along the valley walls. These tracks are up to $30 \mathrm{~m}$ wide and extend from the rim of the gorge to the valley floor with a nearly uniform steep gradient. There are fan-shaped mounds of poorly sorted debris at the end of the debris slide and debris flow tracks (Davies and Ohlmacher, 1977).

Rock falls are prominent near the sandstone cliffs along the rim of the gorge. Most of these falls occur as a single boulder falling from an outcrop. These boulders are up to 30 m wide, with the largest weighing close to 9,000 metric tons (Davies and Ohlmacher, 1977). 
Mills (1990) compared the geology, stream gradient, maximum boulder size, stream width, and valley width to the rating of rapids in the gorge. He examined over 76 $\mathrm{km}$ of the river from Hinton to Hawks Nest Dam, and found that valley cross sections becomes progressively narrower and steeper downstream as the river cuts through more of the extremely resistant New River Formation. Valley width gradually decreases by a factor of 2, as the New River Formation becomes the dominant lithology in the gorge. The maximum boulder size and stream gradient increases by a factor of 3 to 4 in this part of the gorge. Mills (1990) concluded that increased boulder size created a narrow channel width, and increased channel gradient and flow velocity, thus producing more difficult rapids.

Mills (1990) used empirical formulas from Williams (1983) and Knox (1988) to estimate competent flow depths for boulder transport. Williams (1983) formula used 55 measurements by various authors to calculate a regression equation

$$
\mathrm{D}=0.000114 \mathrm{~d}^{1.15} \mathrm{~S}^{-0.62}
$$

where $\mathrm{D}$ is the competent flow depth in meters, $\mathrm{d}$ is clast intermediate diameter in millimeters, and $\mathrm{S}$ is an approximation of the energy slope in $\mathrm{m} / \mathrm{m}$. Knox (1988) used a slightly different data set to derive

$$
\mathrm{D}=0.0001 \mathrm{~d}^{1.21} \mathrm{~S}^{-0.57}
$$

Mills (1990) applied these equations at Fayette Station Rapids where a flood depth of $16.2 \mathrm{~m}$ was measured in 1878 , which corresponds approximately to the $100-\mathrm{yr}$ flood. The largest boulder Mills encountered at the Fayette Station Rapid had an intermediate axis was $3900 \mathrm{~mm}$ and he calculated channel slope as 0.00386. Based on these values, Mills calculated a competent flow depth of $48.2 \mathrm{~m}$ for equation (1) and 52.6 
for equation (2). Based on the comparison of these values with the depth of the 100-yr flood, Mills surmised it would take a discharge three times that of the 100-yr flood to move the largest boulders, suggesting the large boulders were transported to the valley floor by mass movement.

\section{Methods}

Analysis of the three study areas included field mapping, data collection, and comparative analysis. The investigation employed the following methodologies: 1:24,000 scale mapping of mass-movement deposits, development of a spatial database using a Geographic Information System (GIS) to analyze the effects of local bedrock geology, and a statistical analysis of structural variables to quantify their effects on massmovement. In this study, only prehistoric mass-movement deposits have been analyzed because historic mass movements are more related to human activities than a result of natural phenomena.

The distribution of mass-movement landforms in the study areas was mapped at a scale of 1:24,000. Air-photo negatives at a scale of 1:85,000 were enlarged to a scale of approximately 1:8,000 to locate the position of mass-movement deposits. Mapping employed air-photos analysis and field mapping, which was complied onto an USGS 7.5minute quadrangle base map. Each mapped deposit was field checked and evaluated for type of movement, material, relative age, surface hydrology, lithology, orientation, and texture description.

Analysis of local bedrock geology was accomplished by using geologic maps, well data, core data, and measured sections. Analysis of structural geology consists of the acquisition of structural information from the literature and the mapping of lineaments. 
Lineaments are linear topographic features of regional or local extent that are assumed to reflect crustal structures (Bates and Jackson, 1984). In this study, lineaments are defined as topographic low areas with systematic trends, which are greater than $300 \mathrm{~m}$ long and whose trace varies less than $38 \mathrm{~m}$ from a straight line. In order to reduce bias and determine if the results were reproducible two individuals independently mapped these lineaments on separate copies of USGS 7.5-minute quadrangles. The individuals who mapped the lineaments are the primary investigator, Jonathan Remo, and a geologist with extensive lineament-mapping experience, Dr. Henry Rauch. Lineaments were mapped over the entire quadrangle to prevent biased orientations in and around the field areas. Each quadrangle was examined three times by each individual. During each mapping session, the map was rotated periodically to discourage directional bias.

Data from mapping of mass-movement deposits, geologic maps, digital elevation models, and lineament analysis were complied into a GIS database to compare spatial relationships between mass movement deposits, bedrock lithology, and structural conditions. USGS 7.5-minute digital elevation models, Idrisi 7.0, and ArcView 3.0 GIS software were used to create slope and aspect data. Idrisi software was used to calculate the slope and aspect of the gorge walls. Bedrock geology, lineament, and massmovement deposit coverages were created using ARC/INFO 6.0. The areas, slopes, and mean orientation of the mass-movement deposits were calculated using ArcView 3.0 software.

\section{Classification of Mass-Movement}

Varnes's (1984) classification system was used to classify mass movements in the three study areas. Varnes's classification system allows any mass movement to be 
classified and described by an adjective and a noun. The adjective describes the material and the noun describes the type of movement. The types of mass movement in the New River Gorge are predominantly rock fall, rock topple, debris slide, debris flow, or some combination of these types. A complex deposit, as used in this study, is a massmovement deposit that has multiple source areas that merge into one large deposit and incorporate multiple types of mass movement.

The New River Gorge is home to some of the largest boulders in the Appalachian Plateau. The largest boulders mostly occur in the lower gorge study area. To distinguish between extremely large boulders and much smaller boulders, the term "block" will be use in this study to describe boulders with an intermediate axis exceeding $4 \mathrm{~m}$. Mass movement in the New River Gorge study area ranges from relict to active. Determining the age of these mass movements is difficult. Investigation of these massmovement deposits did not reveal any material suitable for radiocarbon dating. Cosmogenic isotope dating may be possible on the quartz sandstone boulders in these deposits. Unfortunately, this study did not have the means to undertake such an analysis. Mass-movement deposits are divided into historic and prehistoric events in this study. Historic mass-movement deposits have formed since settlement of the New River Gorge. Unfortunately, mass-wasting events in the New River Gorge often go unreported if they do not effect humans. The best-recorded event was a large debris slide in the early 1940s that destroyed a company store in South Nuttall (Andre, 1998). Other historic movements can be identified by vegetation damage or by the crosscutting of historic features such as abandoned railroad and road grades. The "prehistoric" age classification 
refers to mass-movement events that have no historic record or cannot be distinguished as historic by crosscutting relationships with historic man-made features.

\section{Mass-Movement Deposits}

Mapping at the scale 1:24,000 resulted in the recognition of 177 mass-movement deposits within the three study areas (table 2).

\begin{tabular}{|c|c|c|c|}
\hline Type of Mass Movement & Upper & Middle & Lower \\
\hline Historic Debris Flow & 1 & 1 & 0 \\
\hline Historic Debris Slide & 0 & 3 & 6 \\
\hline Mine Spoil Slide/Flow & 0 & 15 & 25 \\
\hline Historic Rock fall & 0 & 0 & 1 \\
\hline Prehistoric Rock fall & 0 & 0 & 1 \\
\hline Prehistoric Debris Flow & 1 & 8 & 2 \\
\hline Prehistoric Debris Slide & 11 & 8 & 36 \\
\hline Prehistoric Complex & 0 & 48 & 10 \\
\hline Total & 13 & 83 & 81 \\
\hline
\end{tabular}

Table 2: Results of mapping in the three study areas.

\section{Historic Debris-slide and Debris-flow Deposits}

In the three study areas, there is one mappable historic debris-flow deposit and 10 historic debris-slide deposits, which range in size from $1,000 \mathrm{~m}^{2}$ to $50,000 \mathrm{~m}^{2}$ (figures 79). There are numerous smaller historic debris slides and debris flows that could not be mapped at the scale of this study. Most historic debris slides and debris flows appear related to human activity. Altered drainage or the undercutting of slopes by strip mines, roads, and railroad grades cause historic mass-movements. 


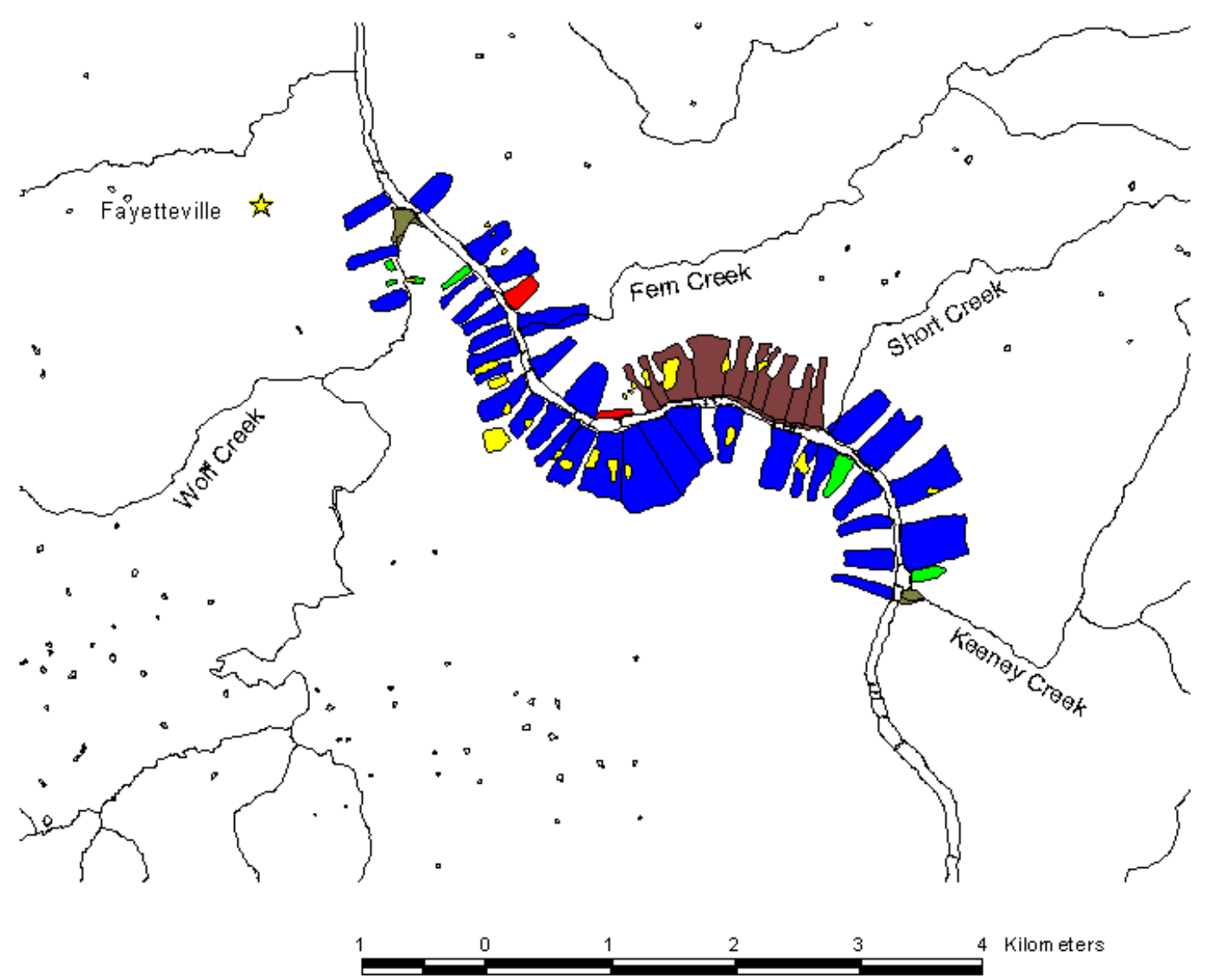

Explanation

Mine Spoil and Mine Refuse Related Slides and Flows

Historic Debris-Slides Deposits

Rock Fall Deposit

Prehistoric Debris-Slide Deposits

Prehistoric Debris-Flow Deposits

Prehistoric Complex Deposits

Figure 7: Map of mass-movement deposits in the lower gorge study area 


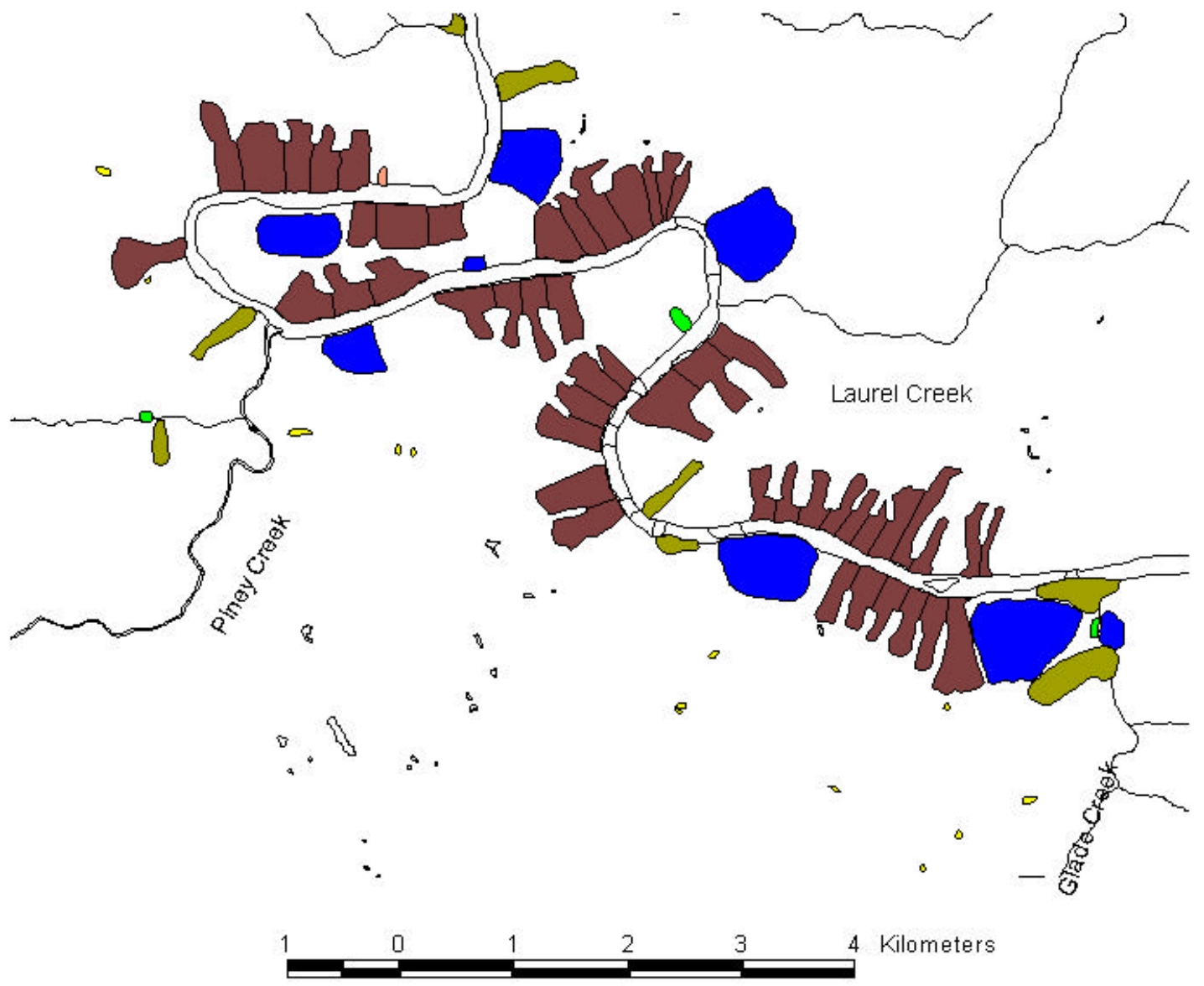

Explanation

Mine Spoil or Mine Refuse Related

Slide and Flow Deposits

Historic Debris-Slide Deposits

Historic Debris-Flow Deposits

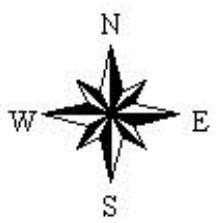

Prehistoric Debris-Slide Deposits

Prehistoric Debris-Flows Deposits

Prehistoric Complex Deposits

Figure 8: Map of mass-movement deposits middle gorge study area. 


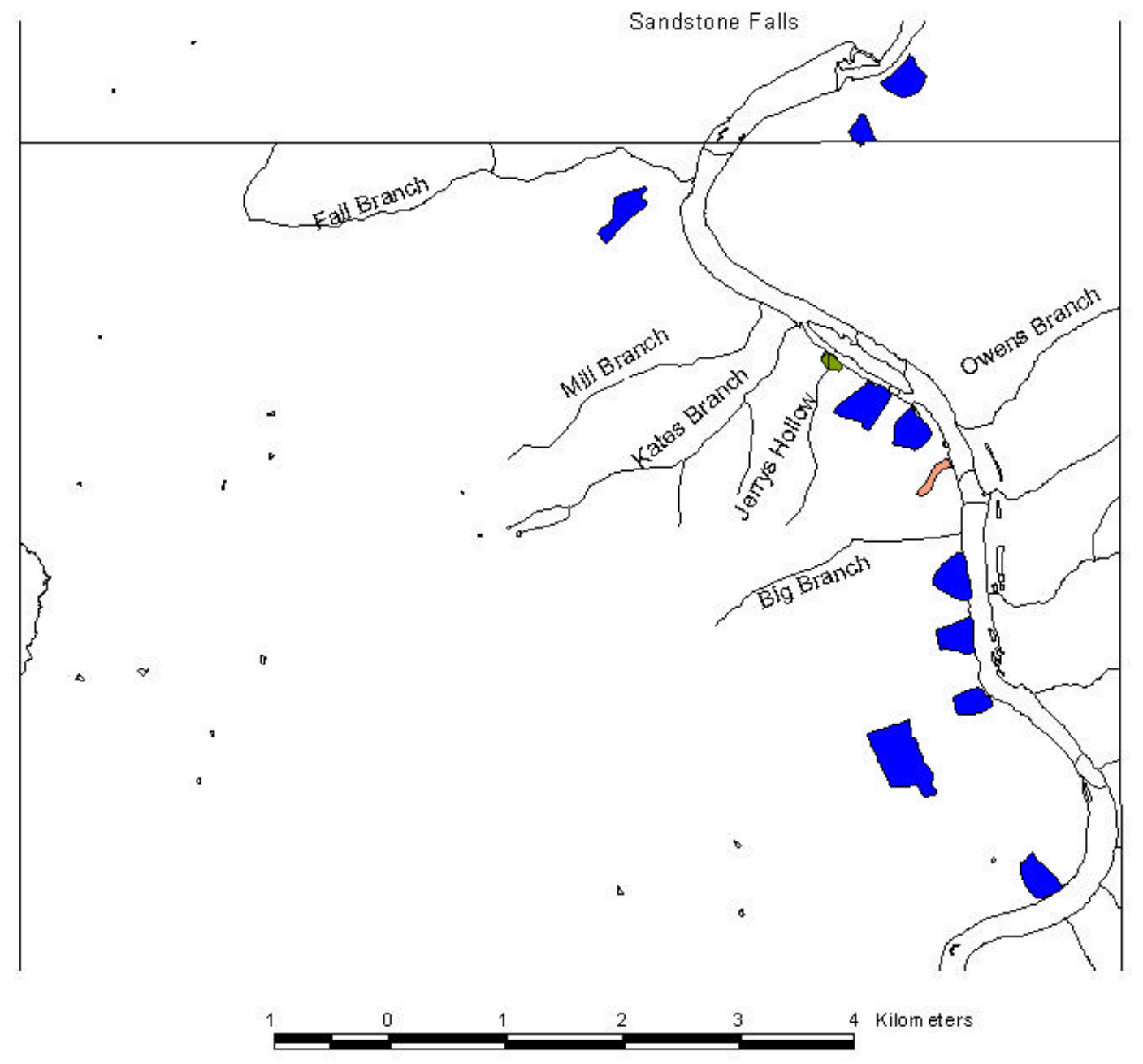

Explanation

Historic Debris-Flow Deposit

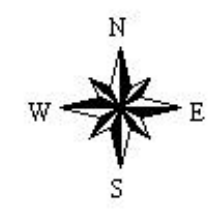

Prehistoric Debris-Slide Deposit

Prehistoric Debris-Flow Deposit

Figure 9: Map of mass-movement deposits in the upper gorge study area. 
Four human activities that contribute to altered drainage are discharge from flooded deep mines, increased discharge from zones that have been auger mined, concentrated shallow ground water, and concentrated overland flow. Increased discharge from deep and auger mining are generally restricted to the lower gorge. There are numerous coal mines in the Sewell Coal along the west valley wall of the lower gorge that have discharge from their entrances adding significant amounts of water to the slopes below. Many of the historic debris slides and debris flows in the lower gorge are found below an outpouring of water from abandoned deep mines. Discharge from an underground mine may have been the cause for the 1940s debris slide below the South Nuttal Mine.

Auger mining along the Sewell Strip Mine bench creates conduits of extreme permeability. During the field investigation, it was noted that the augured zones had significant amounts of seepage wetting slopes below. The concentrated discharge might cause the increased occurrence of small slope failures in these areas.

Road and railroad grades in all three study areas, and strip-mine benches in the lower and middle gorge, intercept and channelize overland flow and shallow ground water flow. The intercepted and concentrated flow from along the strip benches, railroad and road grades eventually finds a point to cross over these manmade features, which significantly increases the volume of water on and within the slope below. This channelization of flow increases the chances of slope failure below that point. Other authors have documented this observation elsewhere and linked it to an increased 
probability of slope failure (Swanson and Dyrness, 1975; Amaranthus and others, 1985; Montgomery, 1994).

\section{Mine Spoil and Mine Refuse Related Mass Movement Deposits}

There are 40 mappable mass-movement deposits related to spoil and refuse piles from strip and deep mining of the Sewell Coal in the lower gorge and Fire Creek Coal in the middle gorge (figures $7 \& 8$ ). Most mining in the New River Gorge ended before the passage of the Surface Mining Control and Reclamation Act of 1977. The spoil and refuse material on the steep slopes of the lower and middle gorge is not stable and often produces debris slides and debris flows. These slides are generally small, ranging in size from $1,200 \mathrm{~m}^{2}$ to $3,900 \mathrm{~m}^{2}$. Mine-spoil and mine-refuse related mass movements commonly occur in small, shallow, steep-sided valleys and extend down slope for up to $300 \mathrm{~m}$. The spoil and refuse material incorporated in these slides and flows is often saturated with water, which causes movement to be rapid (Davies and Ohlmacher, 1977).

Since the end of mining in the New River Gorge, these refuse and spoil pile failures have become less frequent; most of the spoil and refuse piles left in the gorge are relatively stable. Comparison of aerial photography from the mid 1950's to late 1980's shows a significant decrease in these mine spoil and mine refuse related events (Yuill and Armstrong, 1987). Only a few of the mine-spoil and mine-refuse related debris-slide and debris-flow deposits can be seen today because most of the areas have grown over with vegetation. Some of these areas can be distinguished by a difference in vegetation cover. A significant number of these mine-spoil and mine-refuse slides and flows were stabilized by the use of a vine-like plant known as Kudzu, Pueraria thunbergian, a nonnative ground cover-plant introduced from Japan to prevent erosion and stabilize 
slopes in the southeastern United States during the 1920s -1940s (Perez, personal oral communication 1998).

\section{Rock Fall}

Rock fall and topple are common throughout the three study areas. Rock fall is most common below resistant sandstone units in the New River Gorge. Most of these events are too small to be mapped at the scale used for this study, with two exceptions in the lower gorge (figure 7). The first is an area of active rock fall along the railroad grade across the river from Craig Branch. The slope of the valley wall above the railroad grade ranges between $35^{\circ}$ and $65^{\circ}$. A large retaining fence has been placed along the tracks to keep the boulders from falling onto the railroad tracks. Boulders in this deposit are mainly derived from the Pineville Member of the New River Formation and an unnamed feldspathic sandstone unit in the Pocahontas Formation. The second area of mappable rock fall occurs just north of Fern Creek (figure 7). This area of rock fall is prehistoric in age and contains approximately 10 blocks. The slopes above this area of rock fall also range from $35^{\circ}$ to $65^{\circ}$.

The largest blocks in the lower gorge area owe their origin to the extremely resistant Lower Nuttall Sandstone Member of the New River Formation. Large blocks usually begin their journey down slope as a result of block fall or block topple. These block-fall rocks (BFR) appear to develop as single events. BFR usually become perched on the slopes below the Nuttall on their journey down slope. Only in rare cases, such as slopes greater than $35^{\circ}$, do these blocks make it to river level as individual BFR.

Generally, BFR in the lower gorge are orientated with long axis aligned down slope. The 
BFR appear to move down slope incrementally by creep or a slow sliding movement, until they are eventually incorporated into a debris slide or a complex mass movement.

\section{Prehistoric Debris-flow Deposits}

Two prehistoric debris-flow deposits occur in the lower gorge study area. One is located at the mouth of Wolf Creek and the other lies at the mouth of Keeney Creek (figure 7). The area of these deposits is $27,720 \mathrm{~m}^{2}$ for the Wolf Creek fan and 44,250 $\mathrm{m}^{2}$ for the Keeney Creek fan. These two creeks have drainage basin areas of $23.3 \mathrm{~km}^{2}$ and $45.0 \mathrm{~km}^{2}$, respectively, and each enters the New River Gorge with a gradient of 0.10 . These debris-flow deposits are fan shaped and composed of a bouldery diamicton. The mean intermediate axis for the five largest boulders in the debris fans at Wolf and Keeney creeks is approximately $3.1 \mathrm{~m}$. Wolf and Keeney creeks do not dissect these deposits.

The lower gorge study area also has four smaller tributaries that do not contain debris-flow deposits. These tributaries range in drainage area from $1.9 \mathrm{~km}^{2}$ to $4.4 \mathrm{~km}^{2}$ and enter the New River Valley at steep gradients of 0.37 to 0.43 . These streams have associated debris-slide and rock-fall deposits. The difference in the type of mass movement probably is related to the size of the streams. Wolf and Keeney creeks are larger than the other four tributaries. The larger discharge of Wolf and Keeney creeks increases their erosive power allowing the streams to grade into the New River at a gentler slope with wider valleys. The wider valleys and gentler slope allow for the collection and subsequent storage of more colluvial material. The reduced slopes with more accumulated debris material and the greater discharge supplied by Wolf and Keeney creeks make them more conducive to debris flows than debris slides. 
In the middle gorge study area, nine prehistoric debris-flow deposits range in size from $24,900 \mathrm{~m}^{2}$ to $211,600 \mathrm{~m}^{2}$ (figure 8 ). These deposits are fan-shaped landforms, comprised of a bouldery diamicton. The largest boulders incorporated in these deposits are up to $6 \mathrm{~m}$ in the long axis, up to $2.5 \mathrm{~m}$ in the intermediate axis. They are generally composed of conglomeratic quartz sandstones.

Four of the nine prehistoric debris-flow deposits occur in second-order or larger tributaries (figure 8). These deposits are incised up to $2 \mathrm{~m}$ and are generally overlain by a veneer of pebbly, sandy, silty alluvium. The morphology of these deposits is evidence for a debris-flow origin. Boulders that make up these deposits are generally angular in shape, with the largest boulders at the front of the debris fan. Boulders incorporated within these deposits are significantly larger than other boulders and cobbles incorporated in alluvial fans of streams of similar size.

The remaining five prehistoric debris-flow deposits originate in hollows. The term hollow is defined for this study as the central part of a zero-order to a first-orderstream valley, including the channel way. This definition of hollow differs from that of Hack and Goodlett (1960), in that it includes the channelway. Some of these landforms to include younger, smaller fan-shaped deposits on top of older, larger deposits, suggesting these landforms are the result of multiple events.

One 2,200 $\mathrm{m}^{2}$ prehistoric debris-flow deposit occurs in the upper gorge study area. This deposit is located at the mouth of a tributary named Jerrys Hollow (figure 9). The deposit is fan shaped with a cobble-bouldery diamicton, primarily composed of feldspathic sandstone and siltstone. There are four other tributaries similar to Jerrys Hollow that have fan-shaped deposits at their mouths. These fans may be debris flow in 
origin, but due to human disturbance it is extremely difficult to identify and classify these deposits. Boulders and cobbles have been removed from these deposits in order to clear land for cultivation. The boulders were subsequently used for construction.

\section{Prehistoric Debris-slide Deposits}

There are 37 mapped prehistoric debris-slide deposits in the lower gorge study area, ranging in size from $16,700 \mathrm{~m}^{2}$ to $258,000 \mathrm{~m}^{2}$ (figure 7 ). The upper surfaces of these landforms are generally hollows, which may be filled with up to $10 \mathrm{~m}$ of colluvium. Lower surfaces of these lobate landforms are generally hummocky with low, rounded ridges trending across the slide. The textures of these slide deposits are bouldery to blocky diamictons. These debris-slides deposits are derived from colluvial and residual materials derived from the rim and walls of the gorge. Blocks incorporated in these debris-slide deposits are up to $40 \mathrm{~m}$ in long axis, up to $16 \mathrm{~m}$ in the intermediate axis, and weigh up to 16,900 metric tons. The largest blocks observed in this study are up to $10 \mathrm{~m}$ longer and weigh up to 7800 metric tons more than the largest blocks described by Davies and Ohlmacher (1977).

These landforms are interpreted as debris-slide deposits based on a morphology that is dominated by lobate landforms, which are generally hummocky with low rounded ridges. These mass movements do not produce fan-like deposits with bouldery fronts, as is the case with debris-flow deposits. Boulders and blocks are distributed throughout the deposits and are homogeneously mixed with other debris. The debris-slide deposits may incorporate or conceal smaller debris-flow deposits, but this is not apparent from their morphology. Debris-slide deposits in the lower gorge study area occur below hollows. Hollows accumulate colluvial material until the depth of the material reaches a critical 
point that leads to failure. These hollows generally start out as zero-order hollows that channel water over the Lower Nuttall Sandstone. Such zero-order hollows have been documented as the initiation zones for major debris slides and debris flows in studies by Hack and Goodlett (1960) in the headwaters of the Shenandoah River and by Bogucki (1976 and 1977) in Great Smoky and the Adirondack mountains.

Depending on the slope and amount of material incorporated within these debris slides, it may take multiple movement episodes for colluvium to reach river level, as evidenced by colluvial deposits sitting on resistant sandstone benches. Some hollows retain very little residuum and colluvium, suggesting the debris in the hollow was delivered by the most recent event. Most prehistoric debris-slide fans probably were likely to be formed by multiple events, as indicated by smaller debris-slide deposits on top of larger debris-slide deposits.

Eight prehistoric debris-slide deposits occur in the middle gorge field area; these range in size from $24,000 \mathrm{~m}^{2}$ to $43,200 \mathrm{~m}^{2}$ (figure 8 ). These bouldery diamicton deposits are derived from colluvial and residual materials. The quartz sandstone boulders incorporated in the debris-slide deposits are up $6 \mathrm{~m}$ in long axis and up to $3 \mathrm{~m}$ in intermediate axis.

Prehistoric debris-slide deposits in the middle gorge are similar in morphology to those in the lower gorge. Prehistoric debris-slide deposits of the middle gorge area are larger than debris-slide deposits in the lower gorge. The mean area of the debris-slide deposits in the lower gorge is $85,400 \mathrm{~m}^{2}$, versus $271,400 \mathrm{~m}^{2}$ in the middle gorge.

In the upper gorge study area, 10 prehistoric debris-slide deposits range in size from $22,600 \mathrm{~m}^{2}$ to $287,300 \mathrm{~m}^{2}$ (figure 9). The morphology of these debris-slide deposits 
is similar to that for similar deposits in the middle and lower gorge. The textural composition of these prehistoric debris-slide deposits is generally fine grained with few boulders. The boulders are composed of feldspathic sandstone or siltstone and are generally less than $1.5 \mathrm{~m}$ in long and intermediate axis. Only debris-slide tracks that extend up the valley-side walls to the Princeton Sandstone have a significant number of quartz sandstone boulders. Debris-slide deposits with quartz sandstone material occur commonly on resistant feldspathic sandstone benches along the valley wall. In general, these debris-slide deposits are thinner and more dissected than prehistoric debris deposits in the lower and middle gorge study areas.

\section{Prehistoric Complex Deposits}

Ten mappable prehistoric complex deposits occur in the lower gorge study area, ranging in size from $32,800 \mathrm{~m}^{2}$ to $159,400 \mathrm{~m}^{2}$ (figure 7). The morphology and lithology of these complex deposits are similar to debris-slide deposits, except that prehistoric complex deposits have multiple source areas that coalesce into one large deposit and appear to incorporate multiple types of movement.

The middle gorge study area has the most prehistoric complex deposits, with 49 mappable deposits ranging in size from $43,500 \mathrm{~m}^{2}$ to $236,900 \mathrm{~m}^{2}$ (figure 8 ). These complex deposits have two to nine hollows feeding the coalescing deposits. The composition and morphology of these deposits are similar to debris-slide deposits in the middle gorge.

\section{Effects of Lithology on Mass Movement in the New River Gorge}

Bedrock lithology is an important factor to the location, type, size, and preservation of mass-movement deposits in the New River Gorge. Lithology is most 
influential on valley-wall slope and valley-floor width. The steepest and the narrowest sections of the gorge occur where the New River Formation is the dominant lithology.

The number and size of mappable mass-movement deposits varies between the three study areas due to changes in bedrock lithology. The thickness, stratigraphic position, and mineralogy of these units play an important role in the frequency, size, and texture of the mass-movement deposits in the gorge. The percentage of sandstone in the valley walls increases from the upper to the lower gorge study areas (table 3). The upper gorge is the largest of the three study areas but has the least amount of mass-movement deposits. In contrast the lower gorge is the smallest of the three study areas, but has the most mass-movement deposit per-unit area (table 3).

\begin{tabular}{|c|c|c|}
\hline & Percentage of Sandstone & Percentage of Area Covered \\
\hline Study Area & Bedrock in Field Area & By Mass-Movement Deposits \\
\hline Lower Gorge & $48 \%$ & $55 \%$ \\
\hline Middle Gorge & $42 \%$ & $37 \%$ \\
\hline Upper Gorge & $18 \%$ & $4 \%$ \\
\hline
\end{tabular}

Table 3: Percentage of sandstone found in valley walls.

The sandstones of the New River Gorge become more feldspathic in composition and less abundant from northwest to southeast (Englund and others, 1977). The relative area covered by mass-movement deposit decreases from northwest to southeast among the three study areas. These two trends suggest a relationship between area covered by mass-movement deposits and bedrock lithology. The relationship between the percentage of quartz sandstone and the abundance of prehistoric massmovement deposits is related to the preservation of the mass-movement deposits. 
Colluvium and residuum produced by the weathering of shales and feldspathic sandstones are generally clayey fined-grained deposits. Colluvium and residuum produced by the weathering of quartz sandstone yields clasts ranging in size from sand to extremely large blocks. Material derived from quartz sandstone is more difficult to remove from the landscape by fluvial processes than is the finer material derived from feldspathic lithologies.

The increased potential for preservation of mass-movement deposits composed of materials derived from quartzose lithologies increases the chance of subsequent massmovement events adding to the deposits and prolonging the existence of these deposits on the landscape. The less quartzose the debris, the less chance of preservation of these deposits. Mass-movement deposits that consist of quartzose materials are preferentially preserved over mass-movement deposits derived from feldspathic lithologies.

The textures of mass-movement deposits in the upper gorge tend to be the finest found in the three study areas. Boulders in the upper gorge are rarely larger than $1.5 \mathrm{~m}^{2}$ in the intermediate axis. The coarsest debris-slide deposits in the upper gorge have their origin in the Princeton Sandstone. These deposits have significantly more boulders and cobbles than other deposits in the upper gorge. The largest debris-slide deposits in the upper gorge incorporate a large amount of material derived from the Princeton Sandstone. Deposits derived from the Princeton Sandstone are generally twice the size of debris-slide deposits formed exclusively from colluvium and residuum of the Hinton and Bluestone formations.

The middle and lower gorge study areas have similar percentages of sandstone. Sandstones in the middle gorge are generally thinner and more feldspathic in 
composition. Although the sandstones are thinner and more feldspathic in this area, many quartz sandstone units produce large boulders. The mean area of the prehistoric mass-movement deposits in the middle gorge is larger than in the upper and lower gorge. This relationship is probably the result of the combination of factors, such as accommodation space, lithology, and numerous source hollows.

Valley width in the middle gorge is approximately twice that of the lower gorge. The middle gorge has significantly more prehistoric complex deposits than the lower and upper gorge. Complex deposits in the middle gorge are the result of multiple source hollows that coalesce on the wider valley floor. The wider valley of the middle gorge allows for the accommodation of debris over a larger area, thereby allowing larger deposits than occur in the lower gorge. The wider valley bottom in the middle gorge is the probable reason for the large number of complex deposits.

Bedrock in the middle gorge has a combination of weak and resistant lithologies that promotes larger mass-movement deposits than occur in the upper and lower gorge. The less resistant bedrock allows more production of debris per-unit time than resistant lithologies in the lower gorge. However, the debris produced in the middle gorge contains a significant amount of quartz sandstone that favors preservation of the mass movement deposit. In the upper gorge, the lack of resistant lithologies prevents preservation of large accumulations of materials; hence the upper gorge mass-movement deposits are fewer and smaller than the deposits in the middle and lower gorge.

Bedrock lithology affects the type of mass movement. This point can be demonstrated on the steep slopes in the New River Gorge. The steepest slopes in the three study areas are generally greater than $35^{\circ}$ and contain the least amount of colluvial 
materials. Rock fall and rock topple are the predominant types of mass movement on slopes over $35^{\circ}$. In the three study areas, these extremely steep slopes make up less than $13.3 \%$ of the total area of the valley walls. Debris slide and debris flow are the dominant colluvial processes on the slopes under $35^{\circ}$ in the three study areas.

The texture of material that makes up mass-movement deposits also affects the type of mass movement. Mass-movement deposits in the lower gorge consist of numerous large boulders and blocks derived from quartz-sandstone members of the New River Formation. Blocks produced by these quartz sandstones are commonly not equidimensional. Long axes of these blocks are two to eight times longer than intermediate axes. The predominant type of mass movement in the lower gorge appears to be debris slide, because large, elongate blocks and coarse debris materials are not conducive to debris flow.

At least nine mass-movement deposits related to debris-flow occur in the middle gorge. The occurrence of more debris-flow deposits relates to the texture of material derived from weathering of bedrock. Boulders in the middle gorge are generally smaller and more equant than blocks and boulders in the lower gorge. The finer debris and equant boulders are more conducive to debris flow; hence there are more debris-flow deposits in the middle gorge.

The lack of mass-movement deposits in the upper gorge makes it difficult to determine which mass-movement process dominates. Field observation suggests small debris flows and debris slumps, not mappable at the scale used in this study, are the dominant mass-movement processes. 


\section{The Effects of Structure on Mass Movement in the New River Gorge}

Subtle structural features, such as joints, faults, and attitude of beds, contribute to mass movement in the Appalachian Plateau (Craft, 1974; Briggs and others, 1975; Pomeroy, 1982; Jacobson and Pomeroy, 1987; and Outerbridge, 1986). The structural controls on mass movement evaluated in this study are tectonic joints, stress-release joints, lineaments, and attitude of beds.

\section{Joints}

Stress-release joints are bedrock fractures that form valley walls and valley bottoms when the weight of overlying rock is removed by incision and erosion (figure 10). Stress release loosens and weakens the rock enhancing weathering and erosion (Ferguson and Hamel, 1981). Wyrick and Borchers (1981) found that stress-release joints and fractures along the Black Fork River in north-central West Virginia are the dominate controls on the flow and occurrence of ground water. The fracturing caused by stress relief and its effects on hydrology play an important role in mass movement in the New River Gorge.

Stress-release joints can be observed in most of the exposed bedrock in the New River Gorge. The most apparent effects of these joints are on the thick quartz sandstones capping the rim of the middle and lower gorge. Stress-release joints are linear to curvilinear features that propagate parallel to the gorge. These joints produce vertical planes of weakness in quartz sandstones that determine the size and shape of colluvial blocks and boulders. 


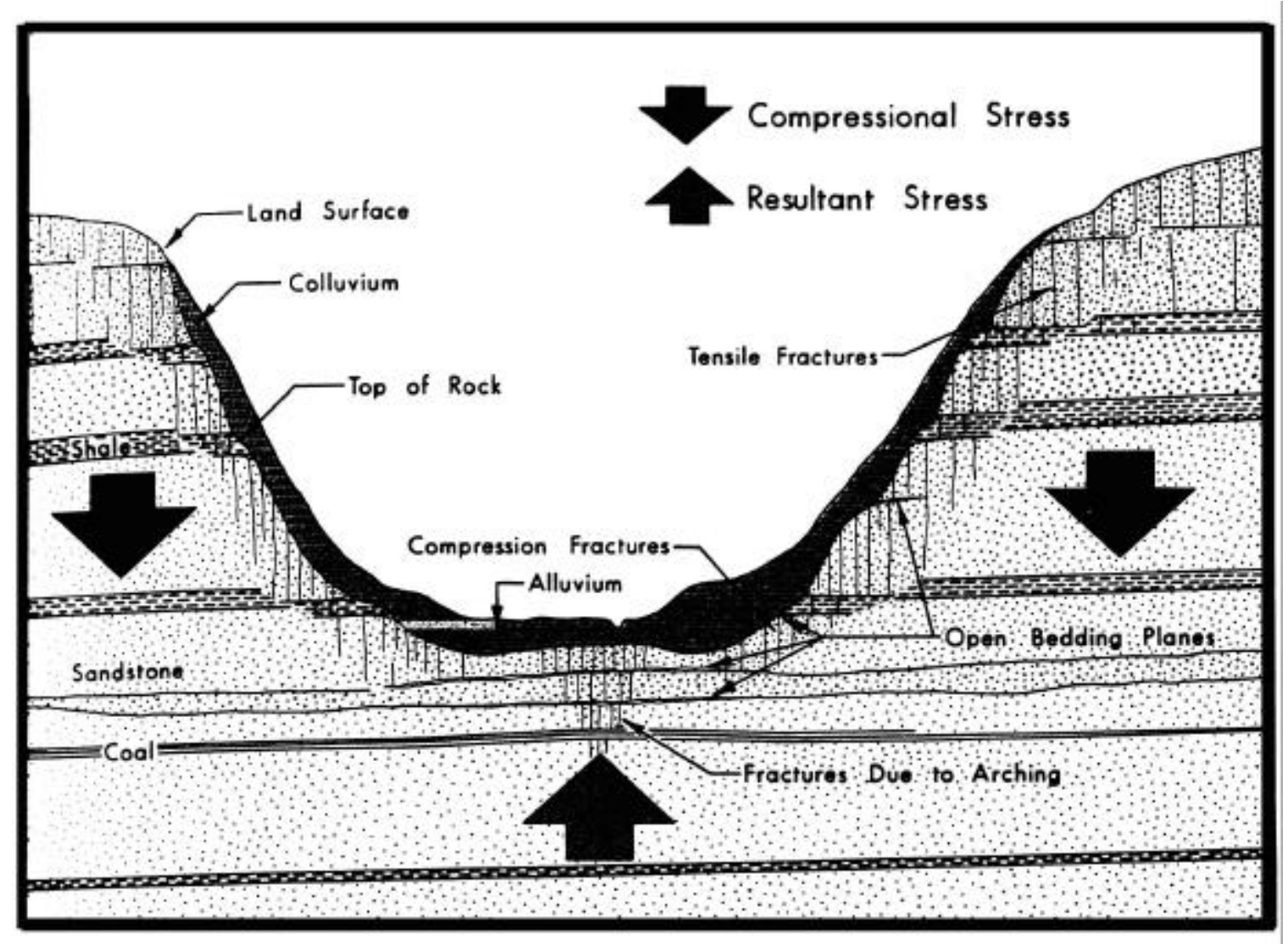

Figure 10: Generalized geologic section showing features of stressrelease joints, from Wyrick and Brochers, (1981). 
Tectonic-joint trends and coal-cleat trends were analyzed to determine if there are preferred orientations of mass-movement deposits in relation to these trends. Tectonic joints and coal cleats represent systematic fractures in the bedrock because of regional or tectonic stress. Joints affect mass-movement by controlling groundwater flow, providing planes of weakness for rock failures to occur, and increasing bedrock weathering and hollow development. These affects may lead to a preferential distribution of massmovement deposits along the coal-cleat and tectonic-joint trends. No joint or coal-cleat trend data was collected in this study. Data from regional studies by Colton and others (1976) and Kulander and Dean (1993) were used to evaluate the structural influence of the orientation on mass-movement deposits.

The joint measurements taken from Colton and others (1976) were given a $\pm 5^{\circ}$ range to allow precision comparable to the orientations of mass-movement deposits as measured on the maps. The area of the mass-movement deposits in all three study areas was summed into $10^{\circ}$ classes based on joint trend classes by Colton and others (1976). The Chi-square goodness of fit test was used to determine if mass-movement deposits are randomly distributed along joint trends. The Chi-square goodness of fit test is calculated using the following equation

$$
\mathrm{X}^{2}=\Sigma(\text { observed }- \text { expected })^{2} / \text { expected. }
$$

(Snedecor and Cochran, 1989).

The observed value used in this equation is given as a percentage of the total area of mass-movement deposits. This percentage is calculated by dividing the area of the mass-movement deposits in each $10^{\circ}$ joint class by the total area of all mass-movement deposits and then multiplying by 100 (table 4). The expected variable 


\begin{tabular}{|c|c|c|c|c|c|}
\hline $\begin{array}{l}\text { Joint } \\
\text { Orientation } \\
\text { Class }\end{array}$ & $\begin{array}{c}\text { Total Area of } \\
\text { Mass-movement } \\
\text { Deposits }\left(\mathrm{m}^{2}\right)\end{array}$ & $\begin{array}{l}\text { Observed \% of Total } \\
\text { Area of Mass- } \\
\text { movement Deposits }\end{array}$ & $\begin{array}{l}\text { Expected \% of } \\
\text { Mass-movement } \\
\text { Deposits }\end{array}$ & $\begin{array}{l}\text { Area with in } \\
\text { a Given } \\
\text { Aspect }\left(\mathrm{m}^{2}\right)\end{array}$ & $\begin{array}{c}\% \text { of Total } \\
\text { Area with in a } \\
\text { Given Aspect }\end{array}$ \\
\hline $0-10$ & 1834645 & 12.98 & 2.78 & 4603500 & 7.32 \\
\hline $10 .-20$ & 476922 & 3.37 & 2.78 & 1908900 & 3.04 \\
\hline $25-35$ & 1061360 & 7.51 & 2.78 & 2293200 & 3.65 \\
\hline $60-70$ & 719186 & 5.09 & 2.78 & 1994400 & 3.17 \\
\hline $70-80$ & 624178 & 4.42 & 2.78 & 1730700 & 2.75 \\
\hline $100-110$ & 131097 & 0.93 & 2.78 & 1476000 & 2.35 \\
\hline $145-155$ & 371178 & 2.63 & 2.78 & 1947600 & 3.10 \\
\hline $160-170$ & 728708 & 5.16 & 2.78 & 2109600 & 3.35 \\
\hline $180-190$ & 1133123 & 8.02 & 2.78 & 2545200 & 4.05 \\
\hline $190-200$ & 219283 & 1.55 & 2.78 & 1839600 & 2.93 \\
\hline $205-215$ & 184350 & 1.30 & 2.78 & 1849500 & 2.94 \\
\hline $240-250$ & 235719 & 1.67 & 2.78 & 1389600 & 2.21 \\
\hline $250-260$ & 232749 & 1.65 & 2.78 & 1252800 & 1.99 \\
\hline $280-290$ & 441529 & 3.12 & 2.78 & 1208700 & 1.92 \\
\hline $325-335$ & 193467 & 1.37 & 2.78 & 1847700 & 2.94 \\
\hline $340-350$ & 130434 & 0.92 & 2.78 & 1938600 & 3.08 \\
\hline \multicolumn{4}{|c|}{ Cumulative Area of Prehistoric Mass-movement Deposits $\left(\mathrm{m}^{2}\right)$} & & 14132313 \\
\hline \multicolumn{4}{|c|}{ Sum of Prehistoric Mass-movement Deposits Associated $w /$ Joint Trends $\left(\mathrm{m}^{2}\right)$} & & 8717928 \\
\hline \multicolumn{4}{|c|}{ Percentage of Total Area of Prehistoric Mass-movement Deposits } & & 61.69 \\
\hline \multicolumn{4}{|c|}{ Cumulative Sum of the Aspect Area $\left(\mathrm{m}^{2}\right)$} & & 62883900 \\
\hline \multicolumn{4}{|c|}{ Sum of Prehistoric Mass-movement Deposits Associated $\mathrm{w} /$ Joint Trends $\left(\mathrm{m}^{2}\right)$} & & 8717928 \\
\hline \multicolumn{4}{|c|}{ Sum of Area With in a Given Aspect Associated with Joint Trends $\left(\mathrm{m}^{2}\right)$} & & 31935600 \\
\hline \multicolumn{4}{|c|}{ Percentage of Total Area of Prehistoric Mass-movement Deposits } & & 61.69 \\
\hline \multicolumn{4}{|c|}{ Percentage of Total Area With in a Given Aspect } & & 50.79 \\
\hline \multicolumn{6}{|c|}{ Chi-square Test } \\
\hline \multicolumn{4}{|c|}{ Degrees of Freedom } & & 14 \\
\hline \multicolumn{4}{|c|}{ Significance Level $(\alpha)$} & & 0.01 \\
\hline \multicolumn{4}{|c|}{ Chi-square Value } & & 65.87 \\
\hline \multicolumn{4}{|c|}{ Chi-square Critical Value } & & 20.09 \\
\hline \multicolumn{6}{|c|}{ Pearson's Correlation Coefficient } \\
\hline r value & & & & & 0.87 \\
\hline
\end{tabular}

Table 4: The data and calculations from the joint trend analysis. The Chi-square test compares tectonic-joint trends with orientation of mass-movement deposits. The Pearson's correlation coefficient compares the total percentage of area with in a given aspect with total percentage of area of the mass-movement deposits along joint trends. 
was calculated by dividing the $10^{\circ}$ in each joint trend, class by $360^{\circ}$ and multiplying by 100 to produce the percentage of $2.78 \%$. This $2.78 \%$ is the expected percentage of the area of mass-movement deposits that should be found in a $10^{\circ}$ joint class if the distribution of mass-movement deposits is a random distribution. The null hypothesis for this Chi-square test is that the distribution of mass-movement deposits is random distribution with respect to joint trends. This null hypothesis was rejected at the 0.01 significance level, suggesting a nonrandom distribution (table 4).

This nonrandom distribution appears to be related to aspect, the down slope direction, of the gorge walls, and is not related to the joint control of the mass-movement deposits. A Pearson correlation coefficient was calculated to determine the relationship between orientation of mass-movement deposits and aspect of the gorge wall along joint trends. The Pearson's correlation coefficient calculates an r-value, which is a dimensionless index that reflects a linear relationship between two data sets. Pearson's correlation coefficient is given by

$$
\mathrm{r}=\mathrm{n}(\Sigma \mathrm{XY})-(\Sigma \mathrm{X})(\Sigma \mathrm{Y}) / \sqrt{\left[\mathrm{n} \Sigma \mathrm{X}^{2}-(\Sigma \mathrm{X})^{2}\right]\left[\Sigma \mathrm{Y}^{2}-(\Sigma \mathrm{Y})^{2}\right]}
$$

where $\mathrm{n}$ in the number of classes, $\mathrm{X}$ is the independent variable, and $\mathrm{Y}$ in the dependent variable (Snedecor and Cochran, 1989). In calculations of the Pearson correlation coefficients, the independent variable is percentage of total area with a given aspect and the dependent variable is the percentage of total area of mass-movement deposits.

The area with a given aspect and the area of mass-movement deposits were summed in the $10^{\circ}$ joint classes based on Colton and others' (1976) joint trends. The percentage of total area with a given aspect and percentage of total mass-movement deposits was calculated for each $10^{\circ}$ joint class. The percentage of total area with a given 
aspect and percentage of total area of mass-movement deposits were calculated by taking the sum of the area within the $10^{\circ}$ classes dividing it by the total area, and multiplying by 100 to produce a percentage (table 4$)$.

The calculated r-value, 0.87 , suggests the distribution of mass-movement deposits along preferred joint trends was not a result of the tectonic joints (figure 11). The amount of mass-movement deposit is more related to aspect. Joint trends that parallel large sections of the gorge wall are associated with more mass-movement deposits than joint trends paralleling smaller sections of the gorge wall.

Coal-cleat trends are the orientations of systematic coal fractures that are distinguished by one or more dominant fracture sets. Kulander and Dean (1993) mapped seven coal-cleat domains in West Virginia based on face cleats. Each of the coal-cleat domains has one or more dominant trends. The major coal-cleat trends in each of the three domains found in the New River Gorge were evaluated for their influence on mass movement (figure 12).

A chi-square test was implemented in order to determine if coal-cleat trends are related to the orientation of mass-movement deposits. Equation 3 was used to calculate the Chi-square value. The observed variable in the Chi-square test is the percentage of total area of mass-movement within the coal-cleat trends. The expected percentage is the same as for the joint trend analysis. The null hypothesis for the Chi-square test is that the distribution of mass-movement deposits is random with respect to the coal-cleat trends. 


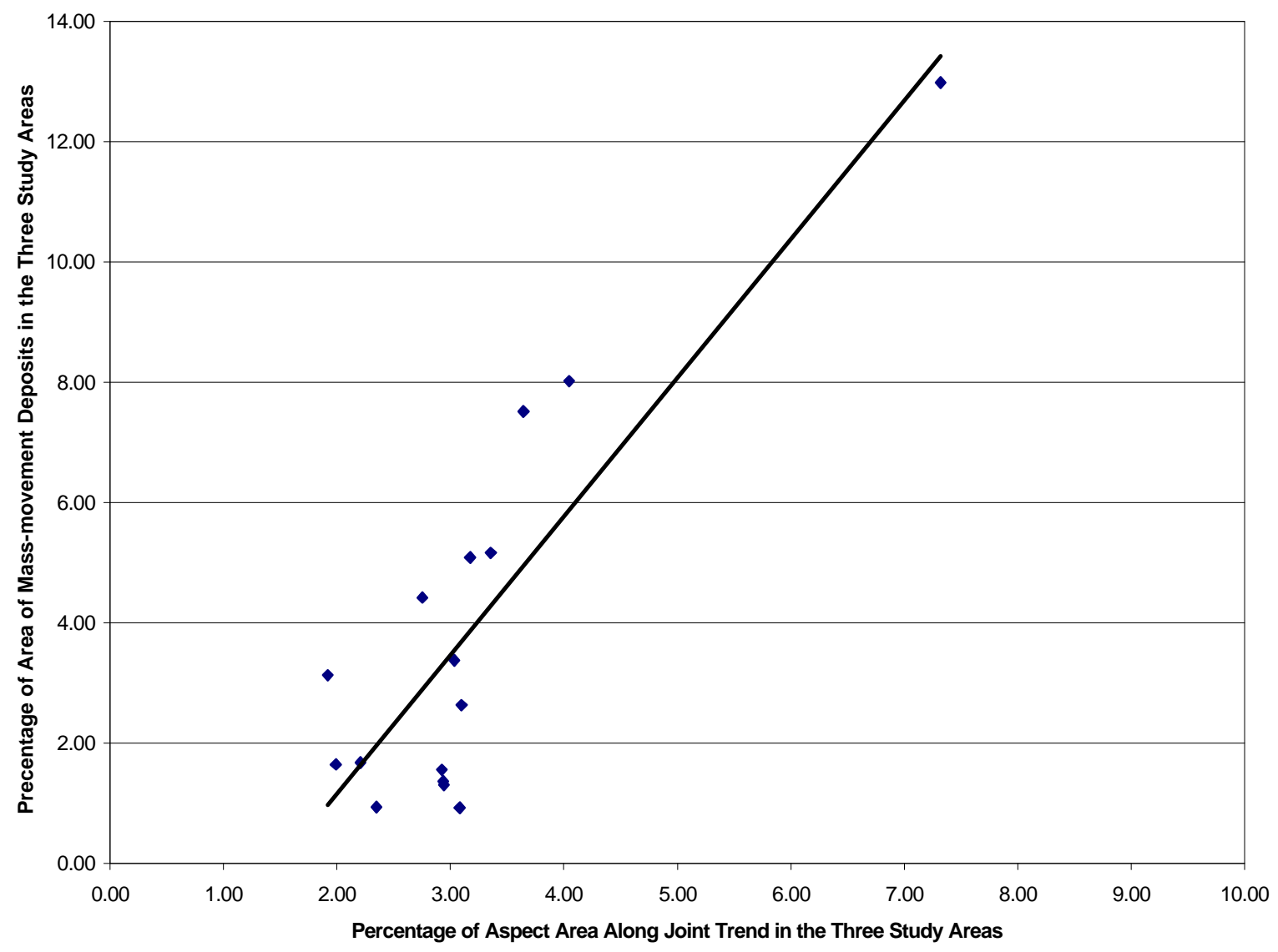

Figure 11: A X-Y plot showing the relationship between the percentage of the total area with a given aspect and the percentage of the total area of mass-movement deposits along joint trends in the three study areas. 


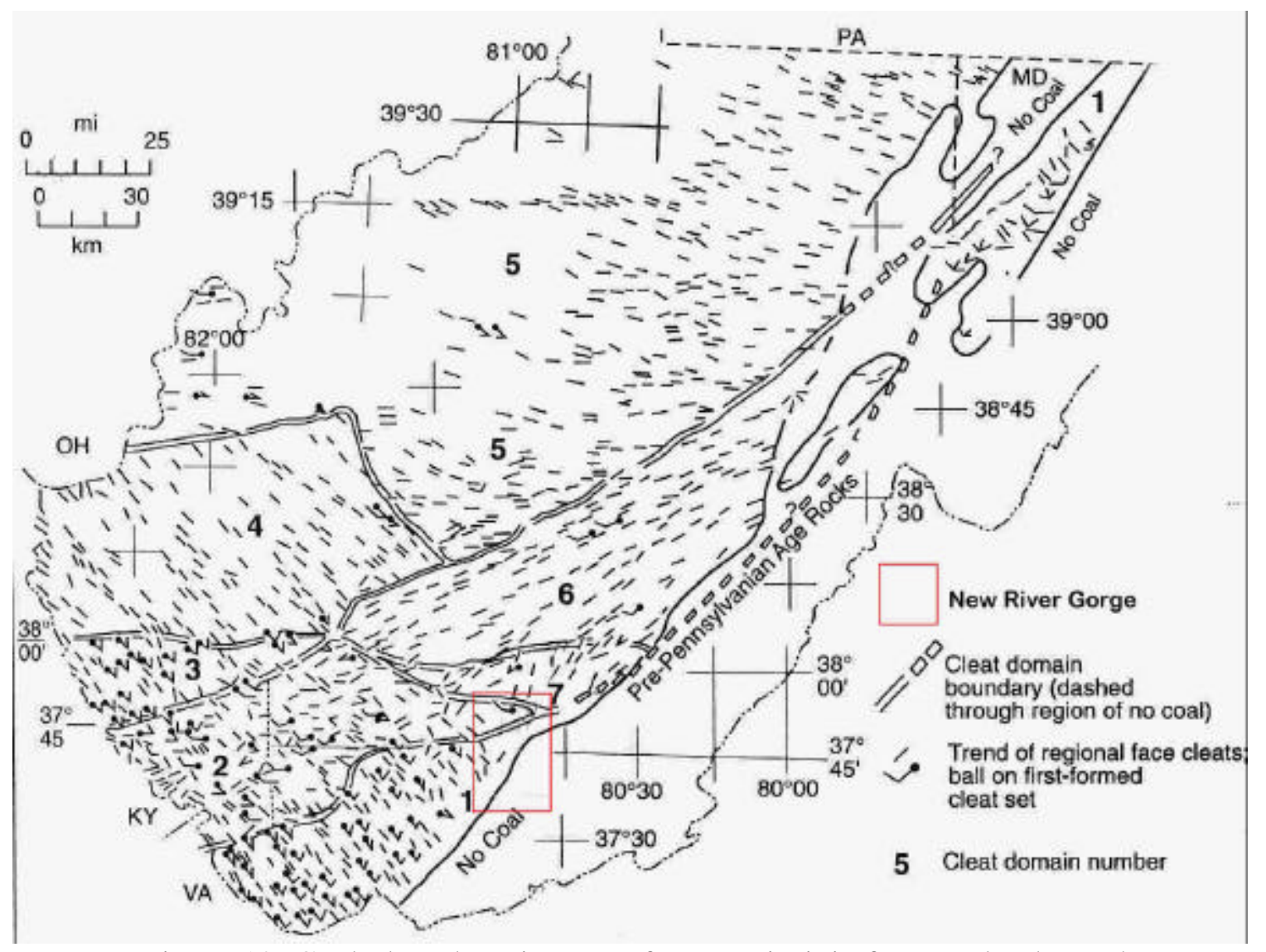

Figure 12: Coal-cleat domain map of West Virginia from Kulander and Dean (1993). 
The null hypothesis could not be rejected for the 0.01 significance level (table 5).

The upper diagram in figure 13; shows the orientation of the prehistoric massmovement deposits, and the lower rose diagram shows the orientation of coal-cleat data from Kulander and Dean (1993). These two rose diagrams and the preceding analysis of tectonic joint and coal-cleat trends, suggest little correlation between the orientation of mass-movement deposits and tectonic joints. The New River Gorge is located on the boundary between three different coal-cleat domains (figure 12) (Kulander and Dean, 1993). It may be difficult to recognize the effect of tectonic joints on the orientation of mass-movement deposits due to the complexity of joint trends in the New River Gorge. Other local geologic features, such as the Mann Mountain anticline, Lawton syncline, Dunn anticline, Springdale syncline and other unnamed folds may locally influence the orientation of joints obscuring any general pattern in New River Gorge (figure 2).

The analysis of coal cleat and tectonic joint trends reveal a strong structural control over the trend of the New River (figure14). The New River between Sandstone and Hawks Nest tends to be aligned northwest with large east-west meanders. Straight reaches of the New River generally trend northwest, parallel to the major coal-cleat trend of $310^{\circ}-330^{\circ}$. The east-west meanders generally follow a secondary coal-cleat trend of $70^{\circ}-90^{\circ}$ (figure 14). A major exception to the $310^{\circ}-330^{\circ}$ and $70^{\circ}-90^{\circ}$ trends is the section of the New River between the town of Thurmond and Keeney Creek where the trend of the New River is $355^{\circ}$ to $005^{\circ}$. The trend of the New River in this area appears to be related to a joint trend of approximately $005^{\circ}$. 


\begin{tabular}{|c|c|c|c|c|c|}
\hline $\begin{array}{l}\text { Coal-cleat } \\
\text { Orientation } \\
\text { Class }\end{array}$ & \begin{tabular}{|c|} 
Total Area of \\
Mass-movement \\
Deposits $\left(\mathrm{m}^{2}\right)$
\end{tabular} & \begin{tabular}{|l|} 
Observed \% of Mass- \\
Movement Deposits
\end{tabular} & $\begin{array}{c}\text { Expected \% of } \\
\text { Mass-movement } \\
\text { deposits }\end{array}$ & $\begin{array}{l}\text { Area With in } \\
\text { a Given } \\
\text { Aspect }\left(\mathrm{m}^{2}\right)\end{array}$ & $\begin{array}{c}\% \text { of Total } \\
\text { Area With in a } \\
\text { Given Aspect }\end{array}$ \\
\hline $10 .-20$ & 476922 & 3.37 & 2.78 & 2087100 & 3.32 \\
\hline $70-80$ & 624178 & 4.42 & 2.78 & 1730700 & 2.75 \\
\hline $80-90$ & 347354 & 2.46 & 2.78 & 1723500 & 2.74 \\
\hline $135-145$ & 58786 & 0.42 & 2.78 & 1884600 & 3.00 \\
\hline $145-155$ & 371178 & 2.63 & 2.78 & 1800000 & 2.86 \\
\hline $190-200$ & 401435 & 2.84 & 2.78 & 2000700 & 3.18 \\
\hline $250-260$ & 232749 & 1.65 & 2.78 & 1380600 & 2.20 \\
\hline $260-270$ & 235985 & 1.67 & 2.78 & 1424700 & 2.27 \\
\hline $305-315$ & 403238 & 2.85 & 2.78 & 1978200 & 3.15 \\
\hline $320-330$ & 207468 & 1.47 & 2.78 & 1883700 & 3.00 \\
\hline \multicolumn{5}{|c|}{ Cumulative Sum of the Area of Prehistoric Mass-movement Deposits $\left(\mathrm{m}^{2}\right)$} & 14132313 \\
\hline \multicolumn{5}{|c|}{ Sum of Prehistoric Mass-movement Deposits Associated w/ Coal Cleat Trends $\left(\mathrm{m}^{2}\right)$} & 3359292 \\
\hline \multicolumn{5}{|c|}{ Percentage of Total Area of Prehistoric Mass-movement Deposits } & 23.77 \\
\hline \multicolumn{5}{|c|}{ Cumulative Sum of the Area With in a Given Aspect $\left(\mathrm{m}^{2}\right)$} & 62883900 \\
\hline \multicolumn{5}{|c|}{ Sum of Aspect Area Associated with Coal-cleat Trends $\left(\mathrm{m}^{2}\right)$} & 17893800 \\
\hline \multicolumn{5}{|c|}{ Percentage of Total Area With in a Given Aspect } & 28.46 \\
\hline \multicolumn{5}{|c|}{ Chi-square Test } & \\
\hline \multicolumn{5}{|c|}{ Degrees of Freedom } & 8 \\
\hline \multicolumn{5}{|c|}{ Significance Level $(\alpha)$} & 0.01 \\
\hline \multicolumn{5}{|c|}{ Chi-square Value } & 4.67 \\
\hline \multicolumn{5}{|c|}{ Critical Value } & 20.09 \\
\hline
\end{tabular}

Table 5: Table showing the results and calculations for the coal-cleat analysis. The Chisquare test compares the association of coal-cleat trends with mass-movement deposits. 
Orientation of Mass-movement Deposits in all Three-Study Areas

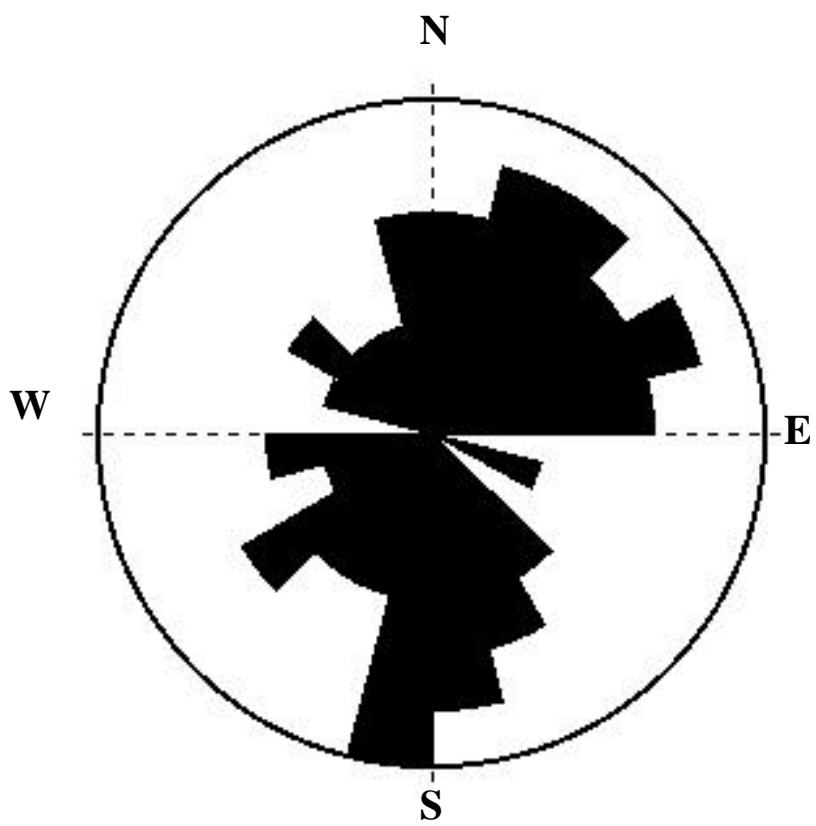

Plot Type: Equal Area Class Size: $\quad 15$ Observations: 124

Orientation of Coal Cleats in the New River Gorge

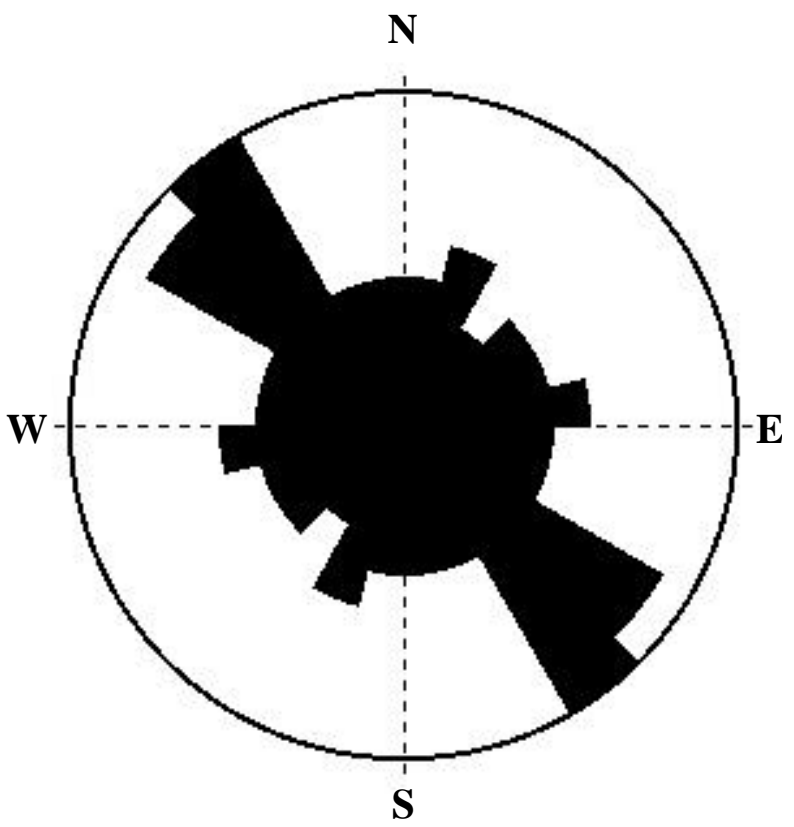

Plot Type: Equal Area

Class Size: $\quad 15$

Observations: 428

Figure 13: Rose diagrams showing the orientation of mass-movement deposits in the three study areas in relation to the orientation of (Kulander and Dean 1993) coal-cleat data. 


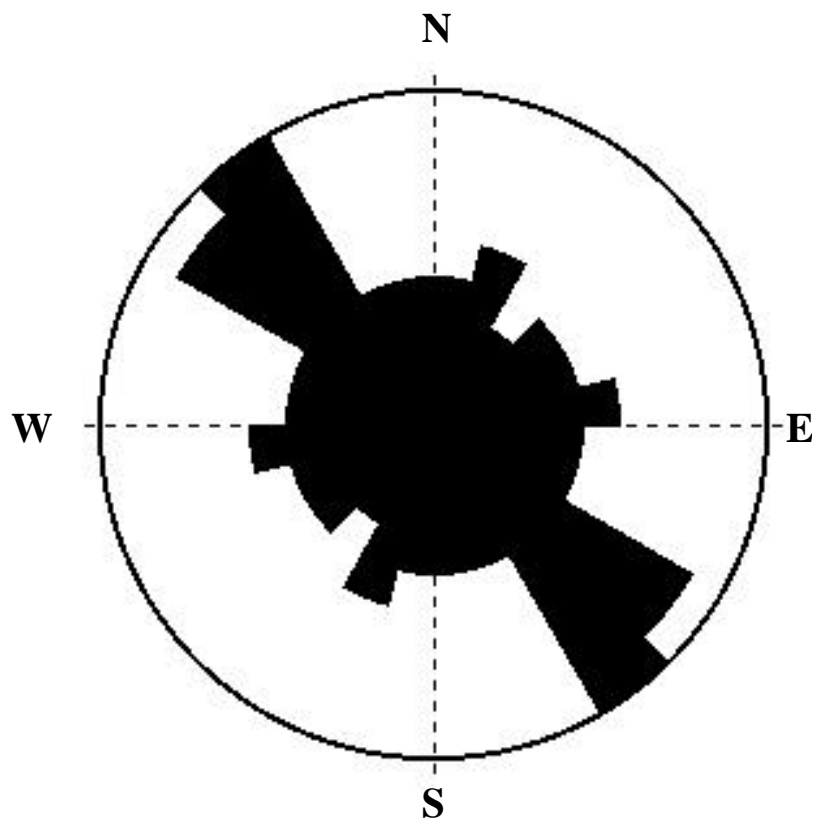

Plot Type: Equal Area

Class Size: $\quad 15$

Observations: 428

Trend of the New River between Hawks Nest and Sandstone, West Virginia.

Plot Type: Equal Area

Class Size: $\quad 15$

Observations: 44

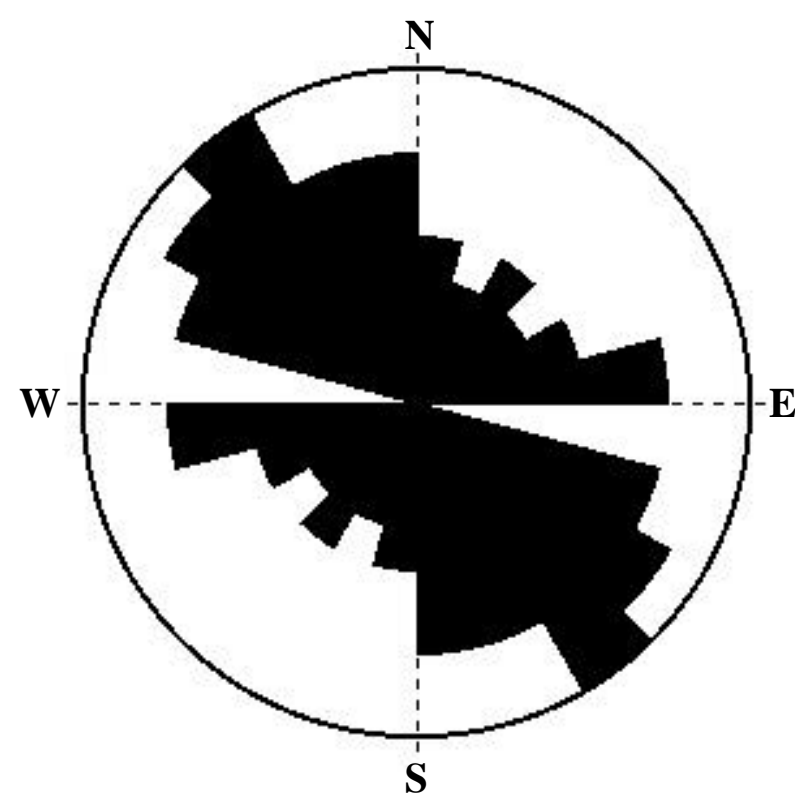

Figure 14: Comparison of coal-cleat orientations with variations in the trend of the New River between Sandstone and Hawks Nest, West Virginia. Coal-cleat data are from Kulander and Dean (1993). 
Additional evidence for structural control of the New River comes from LANDSAT lineaments, curvilinear features mapped from winter and spring LANDSAT images (Reynolds, 1979). Many sections of the New River appear to be influenced by these lineaments (figure 15). Most of the large east-west meanders occur in association with LANDSAT lineaments. The courses of several larger tributaries entering the New River also appear to be influenced by these lineaments.

The joint control of the New River suggests that orthogonal joint trends may influence the orientation of the mass-movement deposits. To investigate this possibility the orthogonal joint trends where calculated from Kulander and Dean (1993) coal-cleat trends. The area of mass-movement deposits found within the orthogonal coal-cleat trends was summed, the percentage of the total mass-movement deposits was calculated and a Chi-square test (equation 3) was used to determine if the deposits were randomly distributed (table 6). The observed variable is the percentage of the total area of massmovement deposits aligned parallel to orthogonal coal-cleat trend. The expected value is calculated by dividing the $10^{\circ}$ in each joint trend, class by $360^{\circ}$ and multiplying by 100 to produce the percentage of $2.78 \%$ the same as it is for the tectonic joint and coal-cleat trend analysis. The null hypothesis for the Chi-square test is that the distribution of massmovement deposits is random with respects to the orthogonal coal-cleat trends. This null hypothesis was rejected at the 0.01 significance level, suggesting a nonrandom distribution (table 6). 


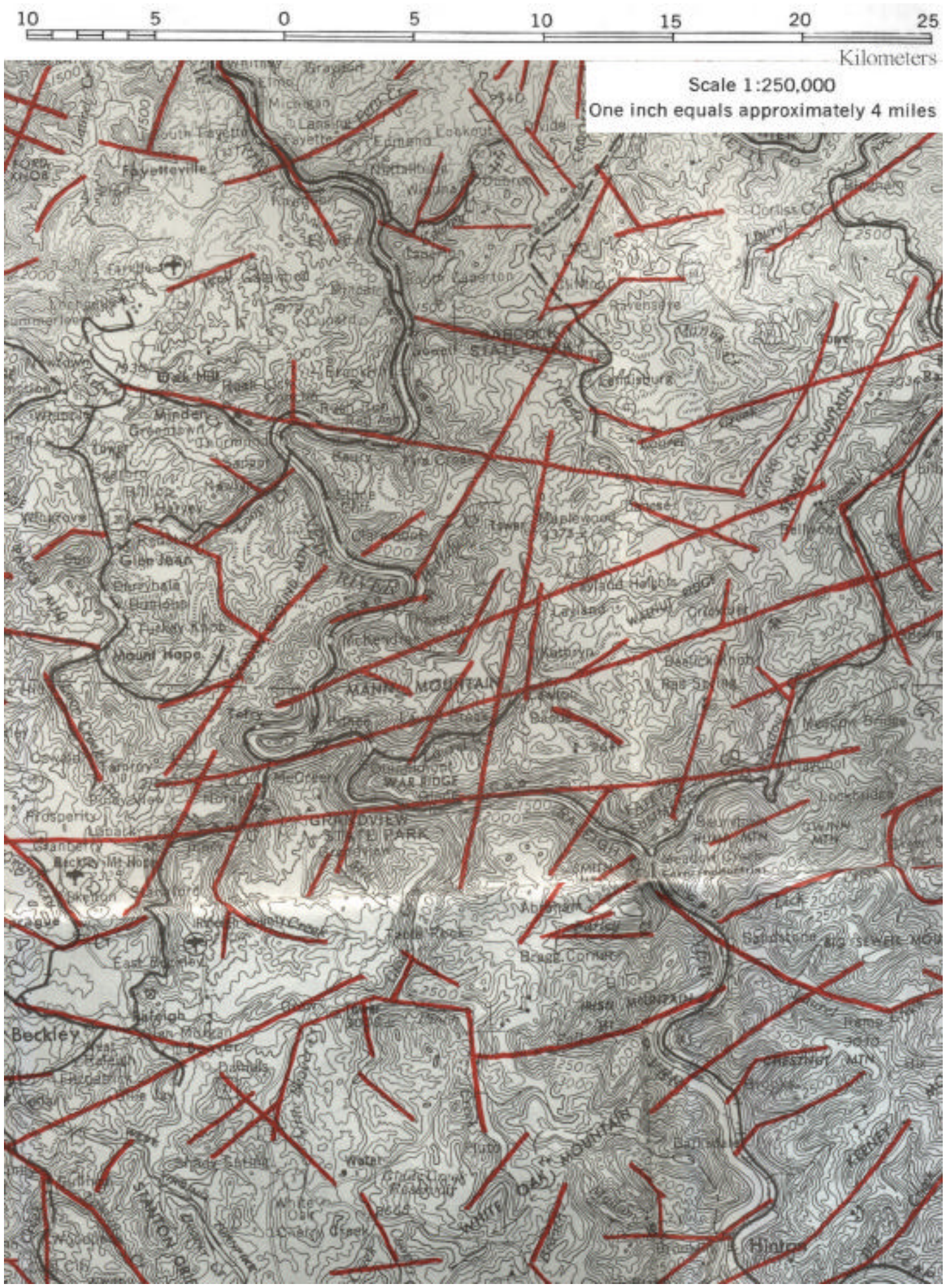

Figure15: Map of LANDSAT Lineaments in and around the New River Gorge (from, Reynolds 1979). 


\begin{tabular}{|c|c|c|c|c|c|}
\hline $\begin{array}{c}\text { Orthogonal } \\
\text { Coal-cleat } \\
\text { Orientation Class }\end{array}$ & $\begin{array}{c}\text { Area of } \\
\text { Mass-movement } \\
\text { Deposits in }\left(\mathrm{m}^{2}\right)\end{array}$ & $\begin{array}{c}\text { Observed Percentage } \\
\text { of Total Area of Mass- } \\
\text { movement Deposits }\end{array}$ & $\begin{array}{c}\text { Expected } \\
\text { Percentage of } \\
\text { Mass-movement } \\
\text { Deposits } \\
\end{array}$ & $\begin{array}{c}\text { Area with } \\
\text { in a Given } \\
\text { Aspect } \\
\left(\mathrm{m}^{2}\right)\end{array}$ & $\begin{array}{c}\text { Percentage } \\
\text { Area with in a } \\
\text { Given Aspect }\end{array}$ \\
\hline $35-45$ & 713596 & 5.05 & 2.78 & 2413800 & 3.84 \\
\hline $50-60$ & 423976 & 3.00 & 2.78 & 2130300 & 3.39 \\
\hline $110-120$ & 155980 & 1.10 & 2.78 & 1700100 & 2.70 \\
\hline $160-170$ & 728708 & 5.16 & 2.78 & 2109600 & 3.35 \\
\hline $170-180$ & 613800 & 4.34 & 2.78 & 2078100 & 3.30 \\
\hline $225-235$ & 751426 & 5.32 & 2.78 & 1904400 & 3.03 \\
\hline $235-245$ & 127853 & 0.90 & 2.78 & 1476900 & 2.35 \\
\hline $280-290$ & 441529 & 3.12 & 2.78 & 1208700 & 1.92 \\
\hline $340-350$ & 130434 & 0.92 & 2.78 & 1938600 & 3.08 \\
\hline $350-360$ & 1517551 & 10.74 & 2.78 & 4050400 & 6.44 \\
\hline \multicolumn{5}{|c|}{ Cumulative Sum of the Area of Prehistoric Mass-movement Deposits $\left(\mathrm{m}^{2}\right)$} & 14132312 \\
\hline \multicolumn{5}{|c|}{ Cumulative Sum of the Aspect Area $\left(\mathrm{m}^{2}\right)$} & 62883900 \\
\hline \multicolumn{5}{|c|}{ Sum of Prehistoric Mass-movement Deposits Associated w / Orthogonal Coal-cleat Trends $\left(\mathrm{m}^{2}\right)$} & 5604853 \\
\hline \multicolumn{5}{|c|}{ Sum of Area With in a Given Aspect Associated with Orthogonal Coal-cleat Trends } & 21010900 \\
\hline \multicolumn{5}{|c|}{ Percentage of Total Area of Prehistoric Mass-movement Deposits } & 39.66 \\
\hline \multicolumn{5}{|c|}{ Percentage of Total Area With in a Given Aspect } & 33.41 \\
\hline \multicolumn{6}{|c|}{ Chi-square Test } \\
\hline \multicolumn{5}{|c|}{ Degrees of Freedom } & 8 \\
\hline \multicolumn{5}{|c|}{ Significance Level $(\alpha)$} & 0.01 \\
\hline \multicolumn{5}{|l|}{ Chi-square Value } & 69.71 \\
\hline \multicolumn{5}{|l|}{ Critical Value } & 20.09 \\
\hline \multirow{2}{*}{\multicolumn{5}{|c|}{ Pearson's Correlation Coefficient }} & \\
\hline & & & & & 0.89 \\
\hline
\end{tabular}

Table 6: The data and calculations for the orthogonal coal cleat analysis. The Chi-square test was used to test the distribution of mass-movement deposits along orthogonal coalcleat trends. The Pearson correlation coefficient was used to test the relationship between the total percentage area with in a given aspect and the total percentage of the area of mass-movement deposits. 
A Pearson correlation coefficient was calculated to compare the percentage of total aspect area with the total percentage of mass-movement deposits (table 6). Equation 4 was used to calculate the Pearson correlation coefficient. The independent variable is the percentage of the total area with in a given aspect and the dependent variable is the percentage of total area of mass-movement deposits. The independent and dependent variables were calculated as outlined in the tectonic joint trend analysis.

The calculated r-value, 0.89 , suggests a strong relationship between the aspect and the orientation of mass-movement deposits (figure 16). The orthogonal coal-cleat trends that parallel large sections of gorge wall are associated with more mass-movement deposits than orthogonal coal-cleat trends paralleling smaller sections of gorge wall. This relationship is the same as the relationship between tectonic joint trends and the orientation of mass-movement deposits.

\section{Lineaments}

The purpose of analyzing lineaments in this study is to determine if these linear features and their associated fracture zones influence the frequency and orientation of mass-movement deposits in the New River Gorge. Lineaments can be singular topographic features of negative relief, or a series of linear features with negative topographic relief. Two individuals, an independent mapper and the primary investigator, mapped lineaments from USGS 7.5-minute quadrangles (figure 17-19). The lineaments mapped in the three study areas for this analysis extend up to $500 \mathrm{~m}$ away from the rim of the gorge and up to 1.6 kilometers up major tributaries. 


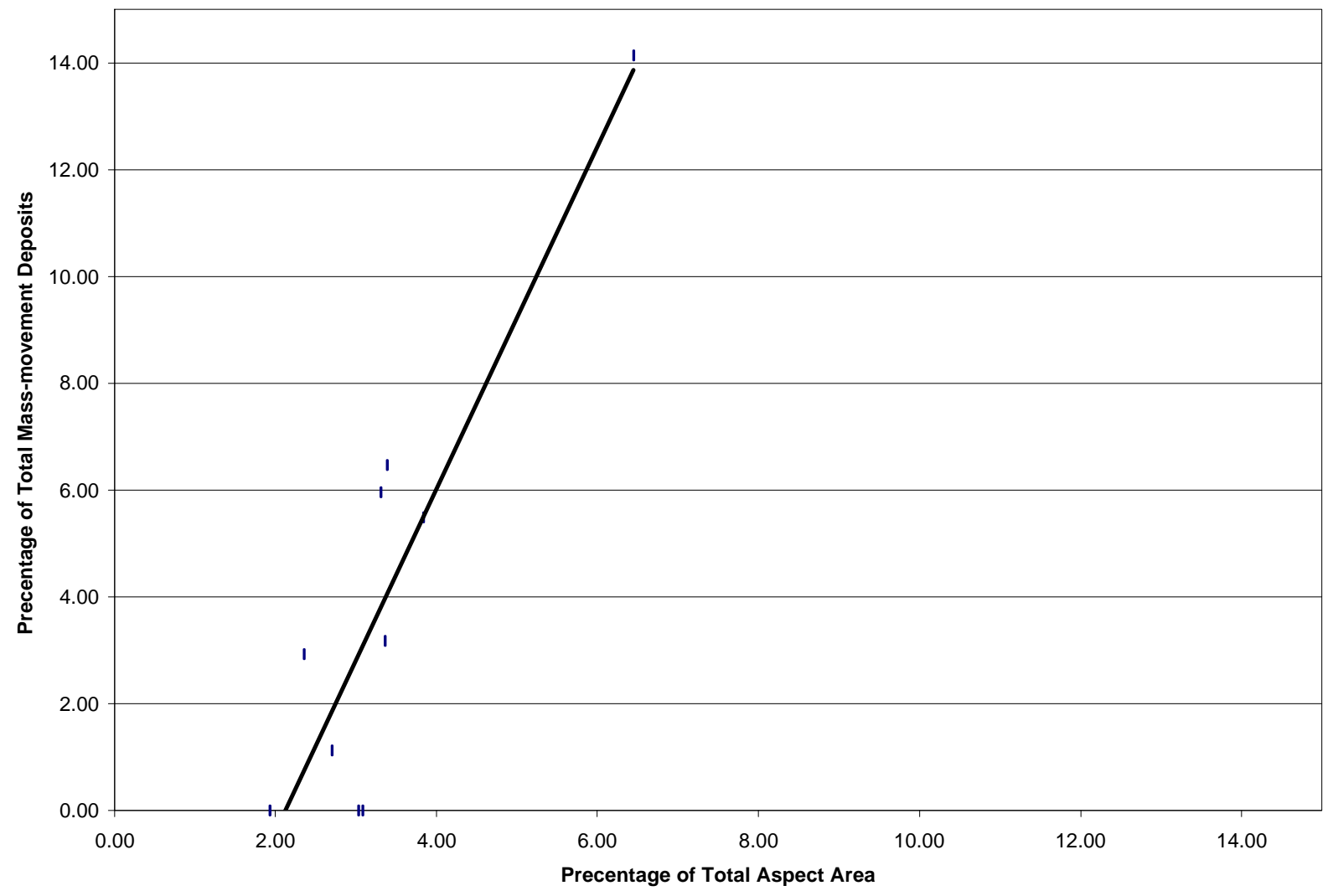

Figure 16: An X-Y plot showing the relationship between the percentage of total area with in a given aspect and percentage of the total area of mass-movement deposits along orthogonal coal-trends in the three study areas. 

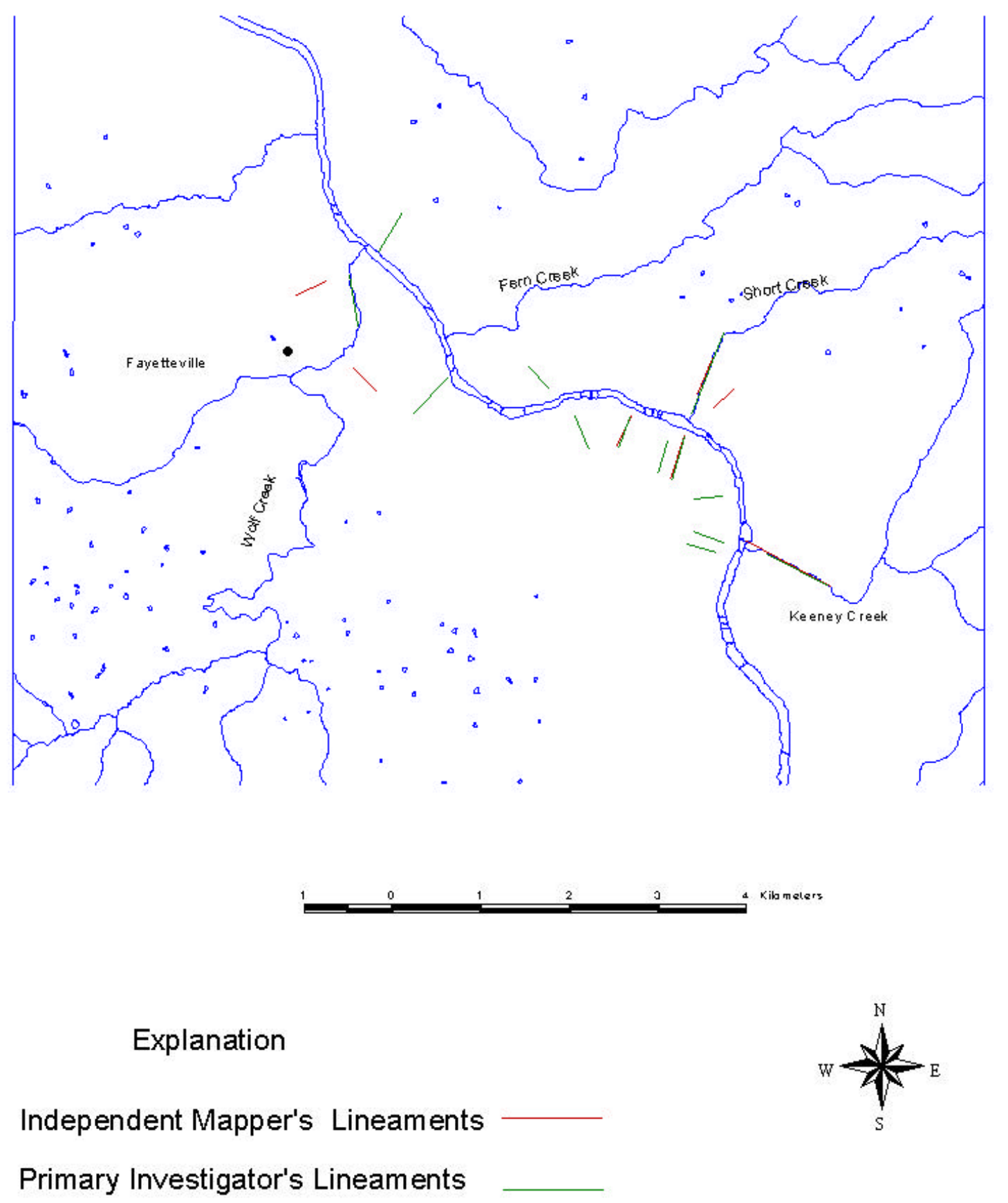

Figure 17: Map of lineaments in the lower gorge study area. 


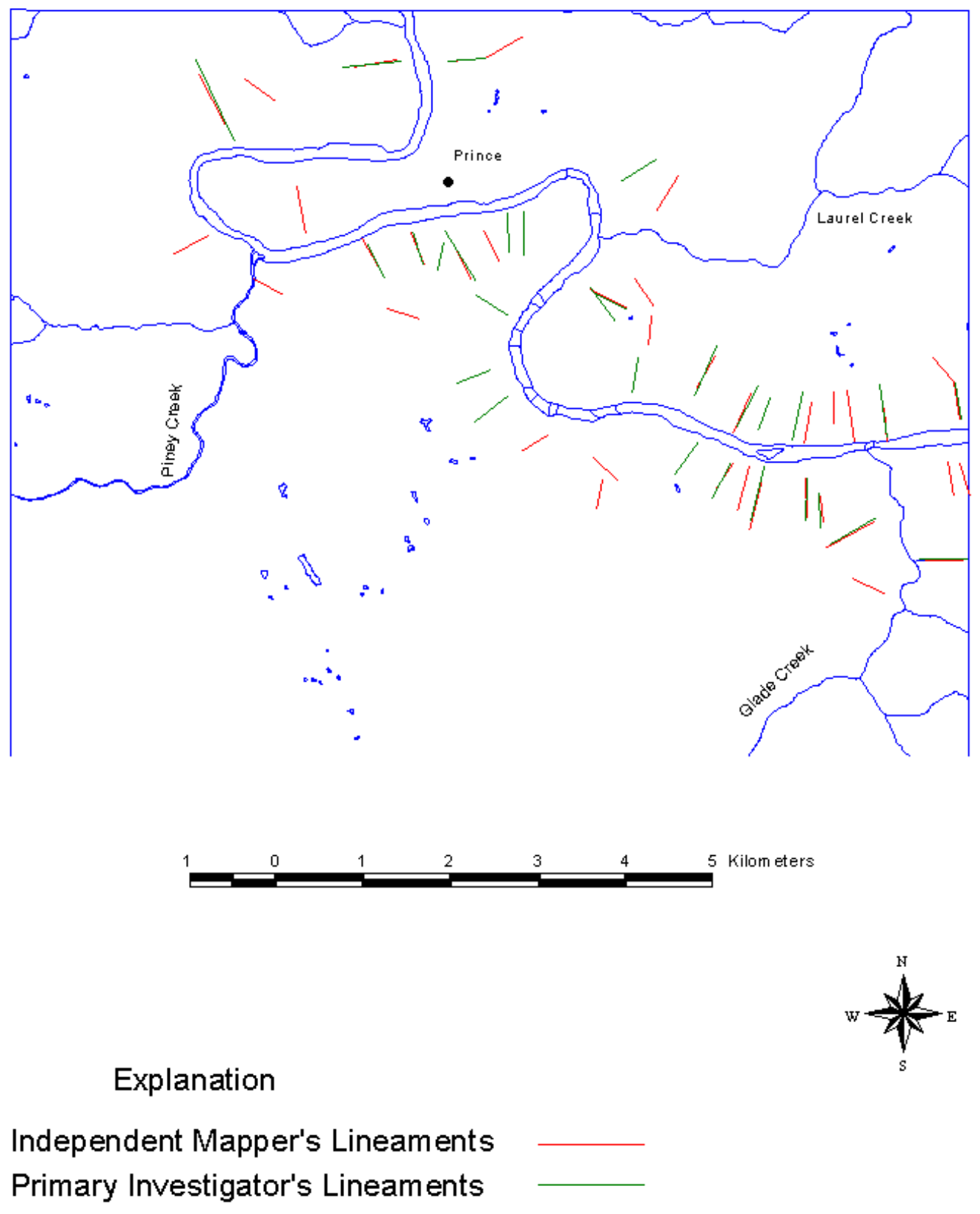

Figure 18: Map of lineaments in the middle gorge study area. 


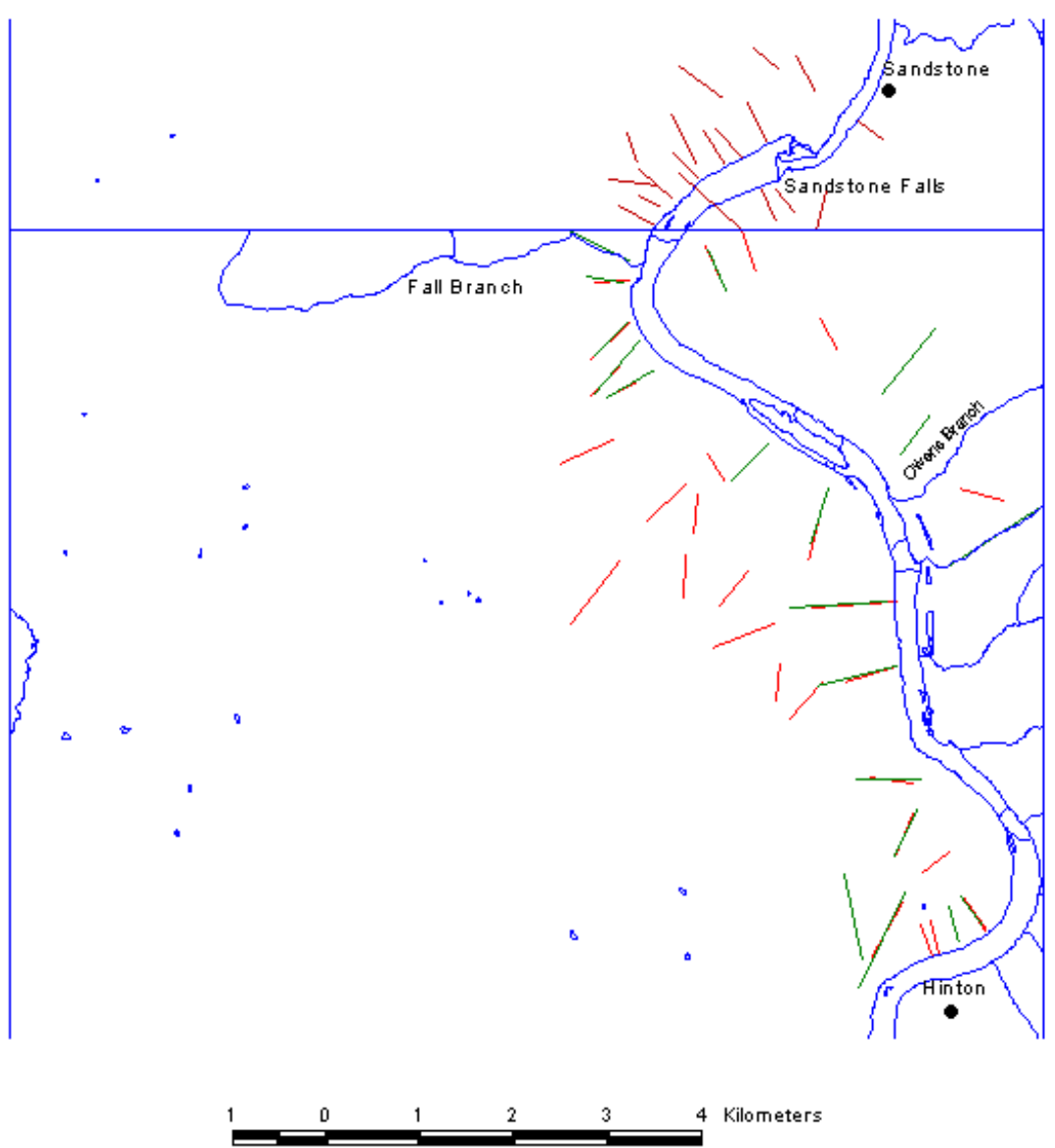

Explanation

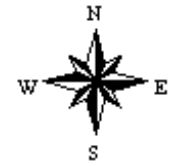

Independ Mapper's Lineaments

Primary Investigator's Lineaments

Figure 19: Map of lineaments in the upper gorge study area. 
The combined mapping by the primary investigator and independent mapper identified 125 linear features in the three study areas. Comparison of lineaments identified by the two mappers revealed significant variation in the number and location of mapped lineaments (table 7). Agreement on the number and location of lineaments ranged between $24 \%$ and $35 \%$ for the three study areas. The percentage of agreement on the identification and location of lineaments between the two individuals was calculated by dividing each lineament data set by the combined lineament data set multiplied by 100 to produce a percentage. The combined lineament data set is the total number of separate lineaments mapped by both individuals. The lower gorge had the fewest mapped lineaments, 17, whereas the upper gorge and middle gorge have 52 and 53 mapped lineaments respectively (table 7).

There are two possibilities for the large difference between the number of mappable lineaments in the lower gorge and the other study areas. The lower gorge has numerous thick quartz sandstones in which linear features may not be as well expressed as in the weaker lithologies of the middle and upper gorge.

Another possible reason for greater number of mappable lineaments in the middle and upper gorge areas is that they are more structurally influenced than the lower gorge. The middle gorge study area includes the Mann-Mountain anticline and the Lawton syncline, whereas the upper gorge study area includes the Springdale syncline, Dunn anticline, and another unnamed folds (figure 2) (Englund and others, 1982). 


\begin{tabular}{|c|c|c|c|}
\hline Study Area & Upper & Middle & Lower \\
\hline \multicolumn{4}{|c|}{ Number of Mapped Lineaments in Field Areas } \\
\hline Independent Mapper & 47 & 39 & 7 \\
\hline Primary Investigator & 24 & 29 & 14 \\
\hline Combined & 56 & 52 & 17 \\
\hline Commonly Mapped Lineaments & 15 & 16 & 4 \\
\hline \multicolumn{4}{|c|}{$\begin{array}{l}\text { Number of Lineaments crossing mapped } \\
\text { Prehistoric Mass-movement Deposits }\end{array}$} \\
\hline Independent Mapper & 3 & 19 & 4 \\
\hline Primary Investigator & 4 & 23 & 8 \\
\hline Combined & 4 & 28 & 8 \\
\hline \multicolumn{4}{|c|}{ Chi-Square Test } \\
\hline \multicolumn{4}{|l|}{ Independent Mapper's Lineament Data Set } \\
\hline \multicolumn{3}{|l|}{ Degrees of Freedom } & \\
\hline \multirow{2}{*}{\multicolumn{3}{|c|}{ Significance Level $(\alpha)$}} & 0.01 \\
\hline Chi-square Value & & & 0.08 \\
\hline \multicolumn{3}{|l|}{ Critical Value } & 6.63 \\
\hline \multicolumn{4}{|c|}{ Primary Investigator's Lineament Data Set } \\
\hline \multicolumn{3}{|l|}{ Degrees of Freedom } & \\
\hline \multicolumn{3}{|l|}{ Significance Level $(\alpha)$} & 0.01 \\
\hline \multicolumn{3}{|l|}{ Chi-square Value } & 5.13 \\
\hline \multicolumn{3}{|l|}{ Critical Value } & 6.63 \\
\hline \multicolumn{4}{|l|}{ Combined Lineament Data Set } \\
\hline \multicolumn{3}{|l|}{ Degrees of Freedom } & \\
\hline \multicolumn{3}{|l|}{ Significance Level $(\alpha)$} & 0.01 \\
\hline \multirow{2}{*}{\multicolumn{3}{|c|}{$\begin{array}{l}\text { Chi-square Value } \\
\text { Critical Value }\end{array}$}} & 0.30 \\
\hline & & & 6.63 \\
\hline
\end{tabular}

Table 7: Tabulated results of the lineament analysis and Chi-square test for the three study areas. 
Lineaments were analyzed for their association with mass-movement deposits. In order for a mass-movement deposit to be interpreted as being in association with a lineament, the lineament must be in contact with the mass-movement deposit. The three lineament data sets combined, independent mapper's, and primary investigator's were analyzed using a chi-square test (equation 3) (table 7). Observed values for the Chisquare tests are the combined number of mapped lineaments associated with massmovement deposits. The expected value for this Chi-square test was calculated by dividing the number of mapped lineaments in each data set by the number of classes. The upper gorge data were excluded from this analysis because of the small population of mapped mass-movement deposits.

The null hypothesis for the Chi-square tests is that the distribution of massmovement deposits is a random with respects to lineaments. The null hypothesis for all three lineament data sets could not be rejected at the 0.01 significance level, suggesting a random distribution. Results from the lineament analysis suggest the mapped lineaments have no direct influence on the location and orientation of mass-movement deposits.

LANDSAT lineaments from Reynolds (1979) that parallel section of the New River were evaluated to see if there was increase amount of mass-movement along these reaches of river. All the mapped prehistoric mass-movement deposits in the three study areas were grouped into two categories, those associated with LANDSAT lineament and those unassociated with LANDSAT lineaments. LANDSAT lineament associated massmovement deposits are defined as mass-movement deposits that either are parallel to reaches of river associated with LANDSAT lineaments or are in direct contact with a 


\section{LANDSAT lineament.}

A Chi-square test was implemented to determine if there was a random distribution of mass-movement deposits parallel to LANDSAT lineaments. The length of the river was computed in the three study areas and separated into two classes, reaches associated with LANDSAT lineaments and reaches not associated with LANDSAT lineaments. Equation 3 was implemented in the calculation of the of the Chi-square value. The percentage of river was calculated for both classifications by dividing the length of the river in each class by the total length of the river in the study area and multiplying by 100 to produce a percentage. The observed values were the percentages of mass-movement deposits along associated and unassociated LANDSAT lineament reaches. The expected values are the percentages of river in each class. The null hypothesis for the Chi-square test is the distribution of mass-movement deposits is a random distribution in both reach classes. This null hypothesis could not be rejected for the 0.01 significance level, suggesting a random distribution. This result suggests there is no significant increase mass-movement deposits along reaches of river associated with LANDSAT lineaments (table 8).

Like tectonic joints lineaments, appear to have little influence on the orientation of mass-movement deposits. The similarity in orientation of coal cleats and the trend of the New River suggest the river is structurally controlled through the New River Gorge. Additional evidence for structural control comes from lineaments mapped from LANDSAT images by Reynolds (1979). An argument can be made that, because the New River is structurally controlled, the mass-movement deposits are indirectly influenced by 


\begin{tabular}{|l|r|r|}
\hline \multicolumn{2}{|c|}{ Lower Gorge Study Area } & $\%$ of Total \\
\hline Length of River in Study Area $(\mathrm{m})$ & 6760 & \\
\hline Stretch of River Associated with Lineaments $(\mathrm{m})$ & 3042 & 45.00 \\
\hline Stretch of River Unassociated with Lineaments $(\mathrm{m})$ & 3718 & 55.00 \\
\hline Area of Mass-movement Deposits on Associated Stretch $\left(\mathrm{m}^{2}\right)$ & 1790520 & 43.54 \\
\hline Area of Mass-movement Deposits on Unassociated Stretch $\left(\mathrm{m}^{2}\right)$ & 2321927 & 56.46 \\
\hline
\end{tabular}

\begin{tabular}{|l|r|r|}
\hline \multicolumn{2}{|c|}{ Middle Gorge Study Area } & $\%$ of Total \\
\hline Length of River in Study Area $(\mathrm{m})$ & 16,770 & \\
\hline Stretch of River Associated with Lineaments $(\mathrm{m})$ & 8,970 & 53.49 \\
\hline Stretch of River Unassociated with Lineaments $(\mathrm{m})$ & 7,800 & 46.51 \\
\hline Area of Mass-movement Deposits on Associated Stretch $\left(\mathrm{m}^{2}\right)$ & 4932844 & 57.88 \\
\hline Area of Mass-movement Deposits on Unassociated Stretch $\left(\mathrm{m}^{2}\right)$ & 3589772 & 42.12 \\
\hline
\end{tabular}

\begin{tabular}{|l|r|r|}
\hline \multicolumn{2}{|c|}{ Upper Gorge Study Area } & $\%$ of Total \\
\hline Length of River in Study Area $(\mathrm{m})$ & 12,290 & \\
\hline Stretch of River Associated with Lineaments $(\mathrm{m})$ & 3,110 & 25.31 \\
\hline Stretch of River Unassociated with Lineaments $(\mathrm{m})$ & 9,180 & 74.69 \\
\hline Area of Mass-movement Deposits on Associated Stretch $\left(\mathrm{m}^{2}\right)$ & 327972 & 27.43 \\
\hline Area of Mass-movement Deposits on Unassociated Stretch $\left(\mathrm{m}^{2}\right)$ & 867895 & 72.57 \\
\hline
\end{tabular}

\begin{tabular}{|c|c|c|c|}
\hline \multicolumn{4}{|l|}{ Analysis } \\
\hline Study Area & Upper & Middle & Lower \\
\hline Percentage of River Associated w/ LANDSAT Lineaments & 25.31 & 53.49 & 45.00 \\
\hline Percentage of River Not Associated w' LANDSAT Lineaments & 74.69 & 46.51 & 55.00 \\
\hline $\begin{array}{l}\text { Percentage of the Area of Mass-movement Deposits } \\
\text { Associated w/ LANDSAT Lineaments }\end{array}$ & 27.43 & 57.88 & 43.54 \\
\hline $\begin{array}{l}\text { Percentage of the Area of Mass-movement Deposits Not } \\
\text { Associated w/ LANDSAT Lineaments }\end{array}$ & 72.57 & 42.12 & 56.46 \\
\hline
\end{tabular}

\begin{tabular}{|lr|}
\hline \multicolumn{1}{|c|}{ Chi-square Test } \\
\hline Degrees of Freedom & 4 \\
\hline Significance Level $(\alpha)$ & 0.01 \\
\hline Chi-square Value & 1.10 \\
\hline Critical Value & 3.75 \\
\hline
\end{tabular}

Table 8: The results of the LANDSAT Lineament analysis and Chi-square test. 
the structure because their location and orientation are dependent on trend of the New River.

\section{Attitude of Bedding}

Bedrock dip influences the type of mass movement occurring from the cliffs of the New River Gorge. Rock falls and rockslides appear more frequently on over-dip slopes, whereas rock topple and rotational rockslide are more common on either reversedip slopes or slopes underlain by flat-lying bedrock. Over-dip slopes are surfaces that slope in the approximate direction of, but more steeply than, the dip of underlying bedrock (Pomeroy, 1982). Reverse-dip slopes are surfaces that slope in the opposite direction from the dip of the bedrock underlying the slope.

In the New River Gorge, over-dip slopes only occur in a few small sections of each of the study areas (figure 2). A structure contour map by Henry and others, (1977) reveal bedrock dip from $1^{\circ}$ to $5^{\circ}$. The New River in the lower gorge runs parallel to the regional dip, except between Keeney Creek and Craig Branch, where the most numerous and largest quartz sandstone blocks occur. Pomeroy (1982), documented an increase in rock fall on over-dip slopes, which may help explain the over-abundance of blocks and boulders in this area.

The mean area of mass-movement deposits in the three study areas is $25 \%$ to $50 \%$ larger on over-dip slopes than on reverse dip slopes and slopes underlain by flat lying strata. The increase in area is not entirely the result of over-dip strata. Many of the overdip slopes are undercut by the New River, which suggests, at a minimum, the 
combination of undercut slopes and over-dip slopes are creating the larger massmovement deposits.

The combination of stress-release joints, thick quartz sandstone, and over-dip strata creates some unusual geologic features. Large crevices, pseudo-karst, and one rock city occur in the lower gorge study area on the east rim of the gorge between Keeney and Short creeks. The large crevices are up to $3 \mathrm{~m}$ wide and $40 \mathrm{~m}$ in length, and are found up to $30 \mathrm{~m}$ from the edge of the gorge. The pseudo-karst features are doline-like features that result from the widening of stress-release joints that allows piping of the overlying soil.

Rock cities are considered periglacial features related to slope process associated with cold Late Wisconsin climate. Rock cities consist of large blocks separated by interconnecting passages aligned along widened joint planes (Smith, 1953; Inners and others, 1993). The only rock city found in the New River Gorge consists of 4 large blocks of sandstone that are approximately $25 \mathrm{~m}$ to $55 \mathrm{~m}$ in length, $20 \mathrm{~m}$ to $40 \mathrm{~m}$ wide, and $3 \mathrm{~m}$ to $5 \mathrm{~m}$ high. Separation of the joints can be as wide as $4 \mathrm{~m}$ both parallel and perpendicular to the gorge. The large blocks quartz sandstone dip toward the gorge at angles ranging from $2^{\circ}$ to $32^{\circ}$.

The combination of stress-release joints and a slope failure surface produce caves in the massive quartz conglomeratic sandstone cap rock of the middle and lower gorge study areas. These caves are the result of rotational rock-block slides in which the stressrelease joint separates from the base of a sandstone block. The massive block slides along a failure surface, creating a cave where the base of a detached block slides away from the stress-release joint (figure 20). These caves are up to $2 \mathrm{~m}$ wide, $2 \mathrm{~m}$ 


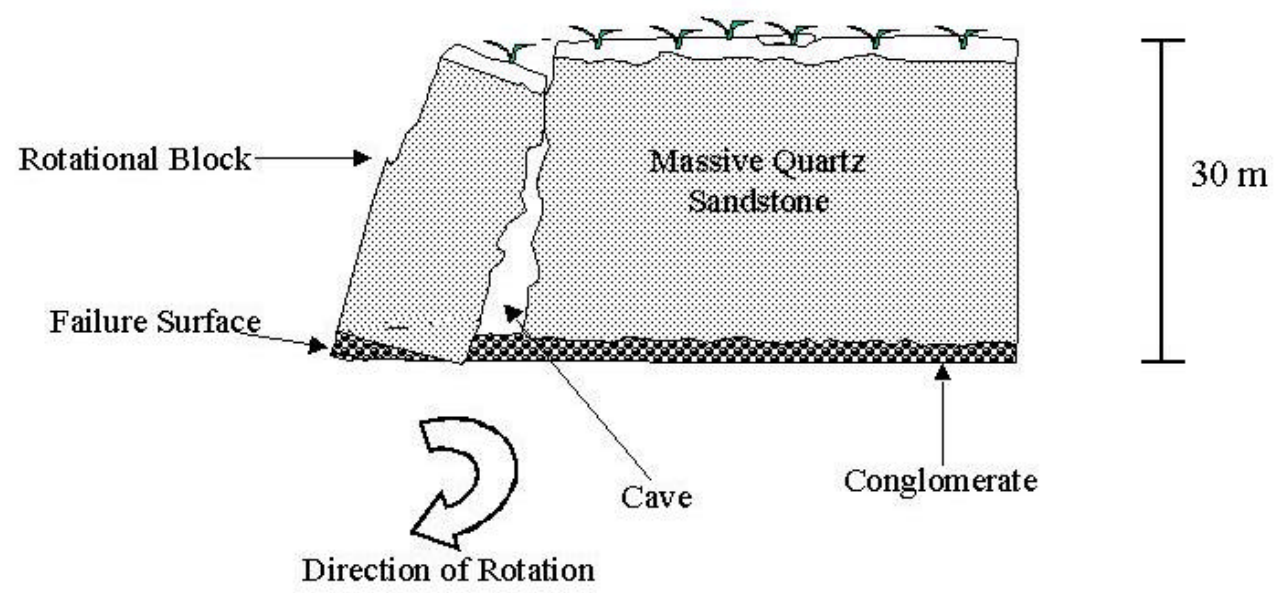

Figure 20: Schematic diagram of caves formed in massive quartz sandstone cap rock of the lower and middle gorge study areas. 
in height, and no longer than $100 \mathrm{~m}$. The most accessible example of this type of cave is at Grandview Park in the middle gorge.

\section{Other Factors}

The route of the New River is another factor to consider controlling of the location and orientation of mass-movement deposits. An analysis was undertaken to determine how the location of the river influences the orientation and location of massmovement deposits. Mass-movement deposits were classified into three classes, based on their location along the river: outside of bends, inside of bends, and straight reaches.

In order to classify these deposits, 1:24,000 scale 7.5-minute USGS Quadrangles were used to map the bends within the three study areas. Dots were placed in the middle of the river on the quadrangle at a spacing of $305 \mathrm{~m}$. Straight lines were then drawn connecting the dots. A bend is defined as a variance greater than $60 \mathrm{~m}$ from a straight line connecting three or more consecutive dots. If the line did not deviate from this $60 \mathrm{~m}$ tolerance, the reach was considered straight. If the river changed orientation along a mass-movement deposit, the deposit was included in the segment in which most of the deposit was mapped.

The outsides of bends show a greater frequency of mass-movement deposits (table 9). In the lower gorge $52 \%$ of mass-movement deposits and in the middle gorge $45 \%$ of mass-movements occur on the outside of bends. Mass-movement deposits on the outside of bends account for a majority of the total area of mass-movement deposits. In the lower gorge $63 \%$ and in the middle gorge $45 \%$ of the total area of mass-movement deposits occur on the outside of bends. The mean area of mass-movement deposits on the outside of bends in the middle and lower gorge is significantly larger than deposits 
Summation of Upper Gorge Study Area Bend Analysis

\begin{tabular}{|c|c|c|c|}
\hline & Inside & Outside & Straight \\
\hline Total & 2 & 2 & 7 \\
\hline \% of Total & 18 & 18 & 64 \\
\hline Total Area & $216,203 \mathrm{~m}$ & $180,246 \mathrm{~m}$ & $791,288 \mathrm{~m}$ \\
\hline \% of Total Area & 18 & 15 & 67 \\
\hline Mean Area & $108,101 \mathrm{~m}$ & $90,123 \mathrm{~m}$ & $113,041 \mathrm{~m}$ \\
\hline
\end{tabular}

Summation of Middle Gorge Study Area Bend Analysis

\begin{tabular}{|c|c|c|c|}
\hline & Inside Bend & Outside Bend & Straight \\
\hline Total & 11 & 29 & 25 \\
\hline \% of Total & 17 & 45 & 38 \\
\hline Total Area & $1,405,267 \mathrm{~m}$ & $3,819,765 \mathrm{~m}$ & $3,334,007$ \\
\hline \% of Total Area & 16 & 45 & 39 \\
\hline Mean Area & $58,552 \mathrm{~m}$ & $159,156 \mathrm{~m}$ & $138,916 \mathrm{~m}$ \\
\hline
\end{tabular}

Summation of Lower Gorge Study Area Bend Analysis

\begin{tabular}{|c|c|c|c|}
\hline & Inside Bend & Outside Bend & Straight \\
\hline Total & 19 & 25 & 3 \\
\hline \% 0f Total & 41 & 52 & 7 \\
\hline Total Area & $1,293,316 \mathrm{~m}$ & $2,581,828 \mathrm{~m}$ & $237,302 \mathrm{~m}$ \\
\hline \% of Total Area & 31 & 63 & 6 \\
\hline Mean Area & $68,069 \mathrm{~m}$ & $103,273 \mathrm{~m}$ & $79,100 \mathrm{~m}$ \\
\hline
\end{tabular}

Table 9: A summary of the analysis of the relationship between mass-movement deposits and New River meander bends. 
on the inside of bends or along straight reaches of the river. The greater frequency and area of mass-movement deposits on the outside of bends probably relates to former undercutting of the slope by the New River. These slopes have produced larger and more numerous failures, thereby influencing the distribution of mass-movement deposits.

Out of 11 mass-movement deposits in the upper gorge, two occur along the outside of bends. Due to the ease with which these deposits are eroded, only a small number are mappable. The small population of mass-movement deposits makes it difficult and problematic to draw significant conclusions; hence, none will be attempted.

\section{Summary}

Bedrock lithology is an important factor affecting size, texture, preservation potential, and type of mass-movement deposits in the New River Gorge. The lower gorge has the most mass-movement deposits per-unit area, followed by the middle gorge, with the upper gorge having the least. The amount of area covered by mass-movement deposits is related to preservation of the deposits. Mass-movement deposits with a high amount of quartz sandstone are preserved on the landscape the longest, while deposits consisting of weaker lithologies are rapidly eroded and removed from the landscape by fluvial processes.

The mean area covered by each type of mass-movement deposit is the greatest in the middle gorge. The explanation for larger mass-movement deposits in the middle gorge relates primarily to three controlling factors. The middle gorge has more accommodation of space for mass-movement deposits than the lower gorge, hence allowing larger deposits to develop in the middle gorge. Most mass-movement deposit 
in the middle gorge have multiple source areas, which coalesce to produce fewer but larger deposits than occur in the lower gorge. Bedrock in the middle gorge has a combination of weak and resistant lithologies that allows the creation of larger massmovement deposits than the upper and lower gorge.

The lower gorge contains the largest blocks because the lower gorge has the greatest abundance of massive quartzose sandstones. Prehistoric debris-flow and complex-debris deposits are more common in the middle gorge study area than in the lower gorge. This trend appears to be a result of the particle size of the colluvial material. The middle gorge material is finer and boulders are more equidimensional than that of the lower gorge. The finer material and more equant boulders make the middle gorge study area more prone to forming debris-flow and complex deposits.

Structural features such as joints, lineaments, and attitude of bedding affect mass movement in the New River Gorge. Stress-release and tectonic joints affect mass movement in the gorge by controlling ground water flow, providing planes of weakness for failure to occur, and providing zones of weakness that may aid development of hollows and colluvial materials along gorge walls. Tectonic joints and lineaments appear to have no direct effect on the orientation or location of mass-movement deposits in the New River Gorge, but they indirectly affect the orientation and location of massmovement deposits by controlling the trend of the New River.

The attitude of bedding appears to affect the type of mass movement along resistant sandstone benches in the New River Gorge. Rock topples and rockslides are more frequent on over-dip slopes, whereas rock falls and rotational rockslides are more common on reverse-dip slopes or slopes underlain by flat-lying bedrock. 
Prehistoric mass-movement deposits in the lower and middle gorge are not graded to the New River, suggesting that the river has eroded the toes of these deposits. Boulder transport calculations by Mills (1990) and the angularity of the large boulders and blocks in the middle and especially the lower gorge suggest the New River is not able to move these large boulders and blocks under current climatic conditions.

Historic mass-movement deposits are significantly smaller than prehistoric deposits. The mean area of prehistoric mass-movement deposits is five times larger than that of historic deposits. The significant difference in size between historic and prehistoric deposits and the inability of the present day New River to remove much of the prehistoric mass-movement deposits, suggests that these deposits are relict landforms formed under different climatic conditions. The drastic differences in size between historic and prehistoric mass-movement deposits suggest that prehistoric mass-movement deposits are related to enhanced weathering and colluviation under climatic conditions associated with one or more of the Pleistocene glaciations. 


\section{References}

Amaranthus, M.P., Rice, R.M., Barr, N. R., and Ziemer, R.R., 1985, Logging and forest roads related to increased debris slides in southwestern Oregon: Journal of Forestry, v. 83, p. 229-233.

Andre, D.A., 1998, The ghosts of Keeney's Creek: Chesapeake Ohio Historical Magazine, v. 30, no. 4, 15 p.

Bates, R.L., and Jackson, J.A., eds., 1984, Dictionary of Geological Terms, $3^{\text {rd }}$ edition: New York, Doubleday, 571 p.

Bogucki, D.J., 1976, Debris slides in the Mt. Le Conte area, Great Smoky Mountains National Park, U.S.A.: Geografiska Annaler, v. 58A, p. 171-191.

Bogucki, D.J., 1977, Debris slide hazards in the Adirondack province of New York State: Environmental Geology, v.1, no. 6, p. 317-328.

Briggs, R.P., Pomeroy, J.S., and Davies, W.E., 1975, Landsliding in Allegheny County Pennsylvania: U.S. Geological Survey Circular 728, 18 p.

Colton, G.W., Perry, W.J., Mackenzie, J.D., 1976, Joint Trends in the Appalachian Basin: U.S. Geological Survey Open-file Report 81-837, 4 Sheets.

Craft, J.L, 1974, Geologic and man-generated factors of urban landslides, Pittsburgh region, Pennsylvania: Geological Society of America Abstracts with programs, v. 6 , no. 7, p. 699 .

Davies, W.E., and Ohlmacher, G.C., 1977, Map of landslides, New River Area, Fayette, Raleigh, and Summers Counties, West Virginia: U.S. Geological Survey OpenFile Report OF-77-76-K, Scale 1:50,000 with text.

Dolan, R., Howard, A., and Trimble D., 1978, Structural Control of the rapids and pools of the Colorado River in the Grand Canyon: Science, v. 202, p. 629-631.

Dyar, R.F., 1957, The Bluestone Group, Princeton Conglomerate, and Hinton Group Mauch Chunk Series in Southeastern West Virginia: West Virginia University, [unpublished M.S. Thesis], 122 p.

Englund, K.J., Arndt, H.H., Henry, T.W., Meissner, C.R., Jr., Windolph, J.F., Jr., and Warlow, R.C., 1977, Geologic map of the New River Gorge Area, Fayette, Raleigh and Summers Counties, West Virginia: U.S. Geological Survey OpenFile Report OF-77-76-A, Scale 1:50,000 with text. 
Englund, K.J., Johnson, P.L., and Arndt, H.H., 1982, Geology of the New River Gorge, West Virginia, in New River Symposium Proceedings, May 6-8, 1982, Beckley West Virginia, p. 136-145.

Ferguson, H.F., and Hamel, J.V., 1981, Valley stress relief in flat-lying sedimentary Rocks: Proceedings of the International Symposium on Weak Rock, Tokyo, Japan, A.A. Balkema, p. 1235-1240.

Gorman, J.L., and Espy, L.S., 1975, Soil Survey of Fayette and Raleigh Counties West Virginia: Washington, D.C., United States Department of Agriculture Soil Conservation Service, $76 \mathrm{p}$.

Griffiths, P.G., Webb, R.H., and Melis, T.S., 1997, Shales and debris flow frequency on the Colorado Plateau, U.S.A.: Geological Society of America Program with Abstracts, v. 29, no. 7, p. 394.

Hack, J.T., and Goodlett, J.C., 1960, Geomorphology and forest ecology of a mountain region in the central Appalachians: U.S. Geological Survey Professional Paper $347,66 \mathrm{p}$.

Hennen, R.V., 1919, Fayette County: West Virginia Geological Survey [county report], $1002 \mathrm{p}$.

Henry, T.W., Warlow, R.C., Windolph, J.F., Meissner, C.R., Englund, K.J., and Ardt, H.H., 1977, Structure contour map of coal bearing rocks of the New River Gorge Area, Fayette, Raleigh, and Summers County, West Virginia: Open-File Report OF-77-76 Map-B, Scale 1:50,000 with text.

Inners, J.D., Sevon, W.D., Moore, M.E., and Berg, T.M., 1993, Rock cities, periglacial mass-wasting, and "honeycomb" weathering in Warren County, northwestern Pennsylvania: Geologic Society of America, Programs with Abstracts, v. 25, no. 2, p. 26.

Jacobson, R.B., and Pomeroy, J.S., 1987, Slope failures in the Appalachian Plateau in Graf, W.L., ed., Geomorphic systems of North America: Boulder Colorado, Geological Society of America, p. 21-33.

Knox, J.C., 1988, Climatic influence on upper Mississippi Valley floods, in Baker, V.R., Kochel, R.C., and Patton, P.C., Flood geomorphology: New York, Wiley, p. 279300 .

Krebs, C.E. and Teets, D.D., 1916, Raleigh County and the Western portions of Mercer and Summers Counties: West Virginia Geologic Survey [county report], 778 p.

Kulander, B.R., and Dean, D.L., 1993, Coal-cleat domains and domain boundaries in the Allegheny Plateau of West Virginia: American Association of Petroleum Geologists Bulletin, v. 77, no. 8, p. 1374-1388. 
Lessing, P., and Erwin, R.B., 1977, Landslides in West Virginia, in Coates, D.R., ed., Landslides: Geological Society of America Reviews in Engineering, v. 3, p. 245254.

Mills, H. H., Brakeridge, G.B., Jacobson, R.B., Newell, W.L., Pavich, M.J., and Pomeroy, J.S., 1987, Appalachian Mountain and Plateaus, in Graf, W.L., ed., Geomorphic systems of North America: Boulder Colorado, Geological Society of America, p. 5-50.

Mills, H.H., 1990, Geologic and topographic controls on the rapids of the New River Gorge, West Virginia: Southeastern Geology, v. 31, no. 1, p. 45-62.

Montgomery, D.R., 1994, Road surface drainage, channel initiation, and slope instability: Water Resources Research, v. 30, no. 6, p. 1925-1932.

Orme, A.R., 1987, Initiation and mechanics of debris avalanches on steep forest slopes: in Beschya, R.L., Blian, T.,Grant, G.E., Swanson, F.J., and Ice, G.G. eds., Erosion and sedimentation in the Pacific Rim: IAHS Publication, no. 165, p. 139-140.

Outerbridge, W.F., 1986, The Logan Plateau, a young physiographic region in West Virginia, Kentucky, Virginia, and Tennessee: U.S. Geological Survey Bulletin $1620,19 \mathrm{p}$.

Pomeroy, J.S., 1982, Landsliding in the greater Pittsburgh Region, Pennsylvania: U.S. Geological Survey Professional Paper 1229, 48 p.

Pomeroy, J.S., and Thomas, R.E., 1985, Geologic relationships of slope movement in northern Alabama: U.S. Geological Survey Bulletin 1649, 13 p.

Perez, J., 1998, Personal Communication, National Park Service, Box 246, Glen Jean, West Virginia 25846.

Reynolds, J.H., 1979, LANDSAT Linear Features of West Virginia: Morgantown, West Virginia, West Virginia Geological and Economic Survey, 1:250,000 scale map, 2 sheets.

Snedecor, G.W., and Cochran, W.G., 1989, Statistical Methods Eighth Edition: Ames, Iowa, Iowa State University Press, 503p.

Smith, H.T.U., 1953, Periglacial frost wedging in the "rock cities" of southwestern New York: Geologic Society of America Bulletin, v. 64, no. 12, p. 1474. 
Sponaugle, K.N., McKinney, D.E., Wright, L.W., Jr., Nelson, C.E., Pyle, R.E., and Mara, C.L., 1984, Soil Survey of Mercer and Summers Counties, West Virginia:

Washington, D.C., United States Department of Agriculture Soil Conservation Service, $173 \mathrm{p}$.

Swanson, F. J., and Dyrness, C.T. 1975, Impact of clear-cutting and road construction on soil erosion by landslides in the western Cascade Range, Oregon: Geology, v .3, p. 393-396.

Varnes, D.J., 1984, Landslide hazard zonation: a review of principles and practice: Paris, France, Darantiere Quetigny, 63 p.

Webb, R.H., Melis, T.S., and McCord, V.A., 1993, Initiation and frequency of debris flows in Grand Canyon: Geological Society of America Programs with Abstracts, v. 25 , no. 7, p. 395 .

Williams, G.P., 1983, Improper use of regression equations in earth science: Geology, v.11, p.195-197.

Wyrick, G.G., and Borchers, J.W., 1981, Hydrologic effects of stress-relief fracturing in an Appalachian valley: U.S. Geological Survey Water Supply Paper 2177, 51 p.

Yuill, C.B., and Armstrong, D. R., 1987, New River Gorge National River mine and well site inventory: Unpublished Report for the National Park Service, 130 p. 


\title{
Modern Day Mass-Movement Rates in the New River Gorge, West Virginia.
}

\begin{abstract}
The New River Gorge of West Virginia provides an excellent opportunity to assess present-day rates of denudation. The geologic history of the New River has created a steep gorge with an abundance of colluvial and residual materials prone to mass wasting. Human development and subsequent abandonment of strip mine benches, road grades, and railroad grades have provided a valuable time line in which to assess denudation via mass movement. This study obtains mass-movement denudation rates by calculating the volume of mass-movement deposits on abandoned road and railroad grades divided by the amount of time since abandonment.
\end{abstract}

Denudation rates were calculated for the slopes underlain by Hinton, Bluestone, and Pocahontas formations. The calculated denudation rate for the Hinton Formation is $71.60 \mathrm{~m} / \mathrm{ma}$, for the Bluestone Formation is $56.45 \mathrm{~m} / \mathrm{ma}$, and for the Pocahontas Formation is $36.02 \mathrm{~m} / \mathrm{ma}$. The Pocahontas Formation is the most resistant of the three units and overlies the Hinton and the Bluestone formations. The long-term denudation rate for the landscape can be no greater than the calculated denudation rate for the Pocahontas Formation. The denudation rate for the Pocahontas is similar to the $36 \mathrm{~m} / \mathrm{ma}$ calculated by Dole and Stabler (1909) for the Southern Appalachians, and to Granger and other's (1997) $27.3 \pm 4.5 \mathrm{~m} / \mathrm{ma}$ Quaternary down-cutting rate of the New River in southwestern Virginia.

An unexpected result this study is that the regional denudation and down- cutting rates are similar to the mass-movement denudation rates found on disturbed slopes of the New River Gorge. It was expected that disturbed slopes in this study would have a 
significantly higher rate of denudation than the average denudation rate for the whole landscape. Human influence is a likely reason for the similarity of denudation rates based on historic sediment studies and mass-movement rates calculated in this study. The similarity between long term down-cutting rates and modern day mass-movement rates is likely related to climate.

\section{Introduction}

Rates of denudation are important for understanding erosion history, landform evolution, and tectonic uplift. Calculation of mass-movement rates allows assessment of landscape stability and rates of denudation. The New River Gorge, West Virginia, provides an excellent area to assess denudation rate via mass-movement. The New River's geologic history has created a steep gorge with an abundance of colluvial and residual materials prone to mass movement. Human development and subsequent abandonment of much of the infrastructure in the gorge have provided well dated surface to assess present-day rate of denudation.

\section{Previous work}

Previously published denudation and erosion rates in the Appalachians range between 1.2 and $203 \mathrm{~m} / \mathrm{ma}$ (Sevon, 1989). Variation in erosion rates reflects differences in geology, neotectonic uplift rates, and land use (Sevon, 1989). Estimations of denudation rates have utilized the following types of data: stream sediment and dissolved loads for large drainage basins, volume of derived sediment, fission-track dating, and cosmogenic-isotope dating.

Dole and Stabler, (1909) calculated a denudation rate of $36 \mathrm{~m} / \mathrm{ma}$ for the Southern Appalachians based on suspended-load and dissolved-load measurements. The highest 
published New River down-cutting rate is $286 \mathrm{~m} / \mathrm{ma}$ (Mills, 1986). Mills (1986)

estimated the New River's down-cutting rate by assigning a Wisconsian 70 ka age, based on the degree of weathering, to the alluvial gravel preserved $20 \mathrm{~m}$ above the river. Since no dateable material could be found on the river terraces, this estimate could not be verified. Granger and others (1997) made an estimation of the New River's down-cutting rate to be $27.3 \pm 4.5 \mathrm{~m} / \mathrm{ma}$. This estimate comes from the use of concentrations of cosmogenic radionuclides ${ }^{26} \mathrm{Al}$ and ${ }^{10} \mathrm{Be}$ in alluvium deposited in caves to infer the time of deposition. By using the time of deposition and the subsequent change in river level, Granger and others, 1993 calculated a down-cutting rate.

Other indirect erosion-rate estimates for the New River have been made by Houser (1981) and Bartholomew and Mills (1991). Houser (1981) presents an estimate of $40 \mathrm{~m} / \mathrm{ma}$ based on Hack's (1965) analysis of modern sediment load on the nearby South Fork of the Shenandoah River. Bartholomew and Mills (1991) consider a range of estimates from $40 \mathrm{~m} / \mathrm{ma}$ based on erosion rates from Hack (1979), to $55 \mathrm{~m} / \mathrm{ma}$ based on Schmidt's (1982) down-cutting rate for the Green River, Kentucky inferred from cave sediment magnetostratigraphy.

\section{Physical Setting}

The three study sites for this investigation lie within the New River Gorge National River between the towns of Meadow Creek and Thurmond, West Virginia (figure 1). Two of the three study sites occur near the town of Thurmond, in the Thurmond quadrangle. The third study site is located near Glade Creek in the Meadow Creek and Prince quadrangles (figure 1). 

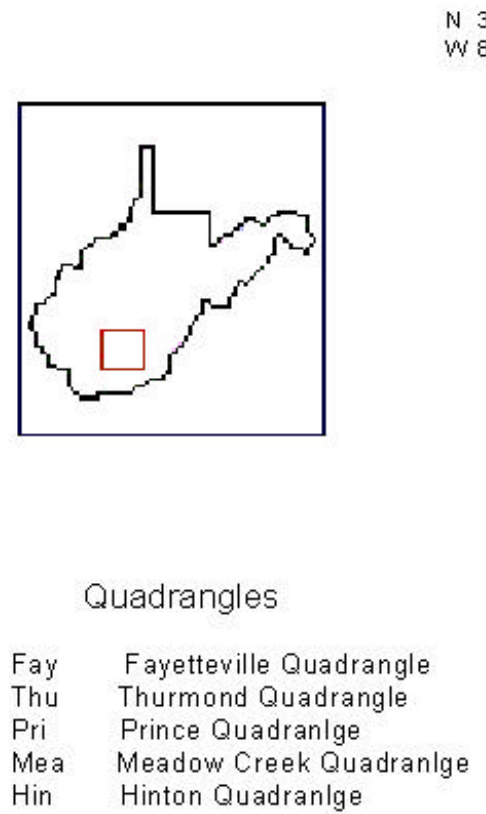

Quadrangles

$\begin{array}{ll}\text { Fay } & \text { Fayetteville Quadrangle } \\ \text { Thu } & \text { Thurmond Quadrangle } \\ \text { Pri } & \text { Prince Quadranlge } \\ \text { Mea } & \text { Meadow Creek Quadranlge } \\ \text { Hin } & \text { Hinton Quadranlge }\end{array}$

N 38073

N 810730

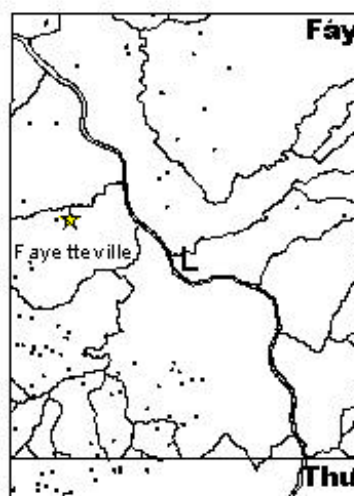

N 380000

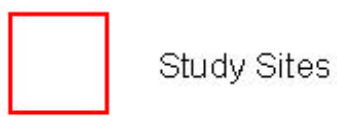

N 374500

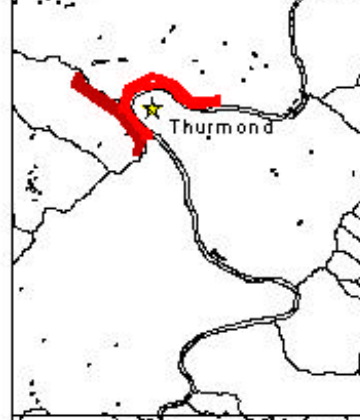

5230

W 805230

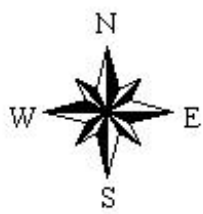

15 Kilom eters

Figure 2 - 1: Study Site Map. 
The study sites are underlain by four major geologic formations (figure 2). The Upper Mississippian Hinton Formation is the oldest rock unit exposed in the gorge and is composed primarily of calcareous shale and siltstone with lesser amounts of limestone and sandstone. The most resistant member of the Hinton is the $30 \mathrm{~m}$ thick Stony Gap Sandstone, composed largely of quartz sandstone. The Hinton is unconformably overlain by the Upper Mississippian Bluestone Formation, which consists mainly of nonresistant shale, siltstone, and limestone with thin sandstone beds. The only resistant member of the Bluestone Formation is the Glady Fork Sandstone Member, which ranges in composition from silty ripple-bedded sandstone to coarse conglomeratic sandstone (Englund and others, 1977; Englund and others, 1982).

The Lower Pennsylvanian Pocahontas Formation lies above the Bluestone Formation. The Pocahontas Formation consists of $70 \%$ sandstone, $28 \%$ shale, $2 \%$ coal and underclay. The Flattop Sandstone is the only name quartz sandstone in the Pocahontas Formation unit, but there are numerous unnamed quartz sandstone units (Englund and others, 1977; Englund and others, 1982).

The Lower Pennsylvanian New River Formation unconformably overlies the Pocahontas Formation. The New River Formation is a coal-bearing sequence of sandstone, siltstone, shale and underclay. The New River is lithologically similar in composition to the Pocahontas, except for thicker and more widespread sequences of conglomeratic quartz sandstones. The most resistant members of the New River 


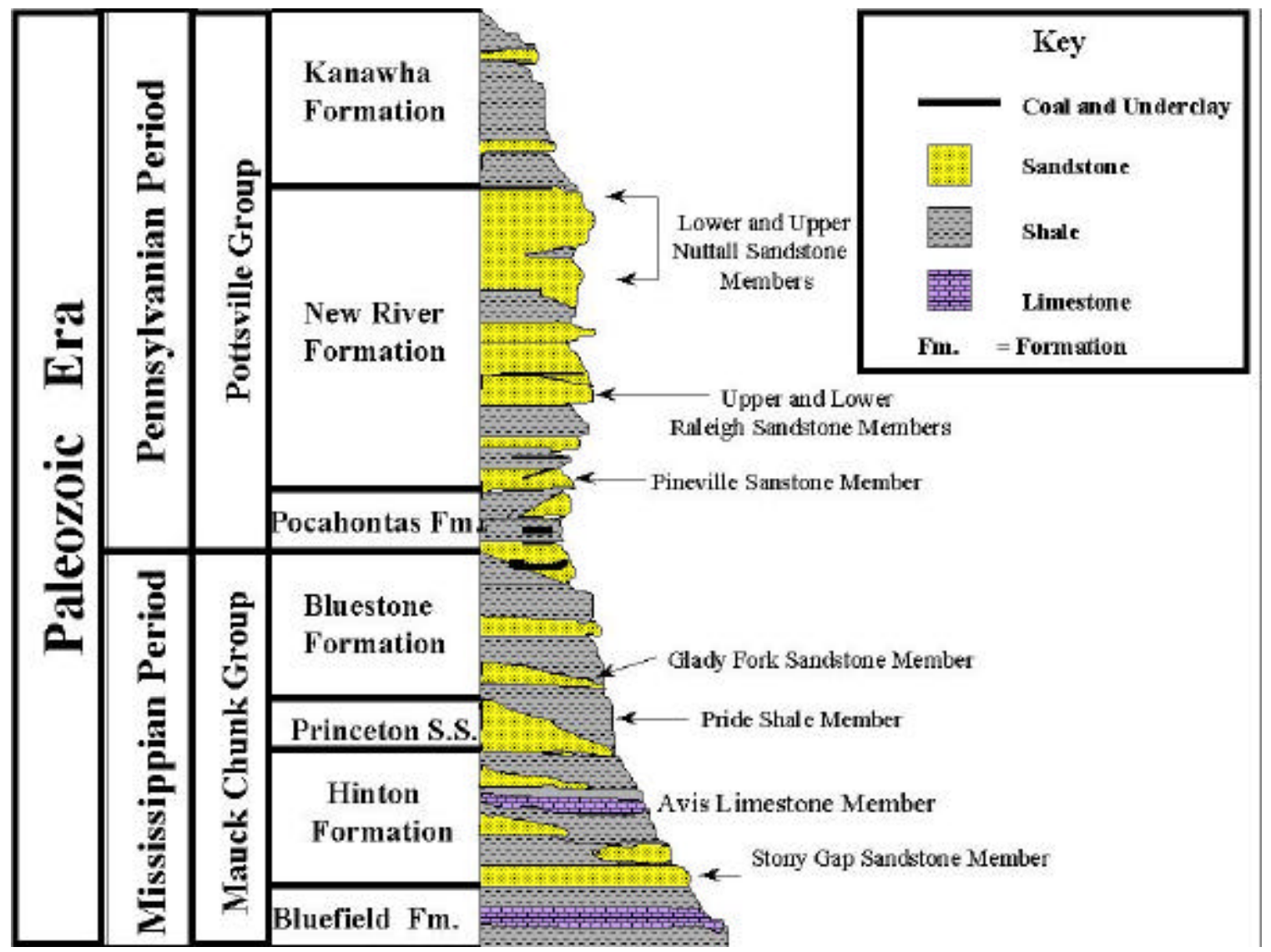

Figure 2 - 2: Generalized columnar section of bedrock exposed in the New River Gorge. Modified from (Englund and others, 1982). Not to scale. 
Formation are the Upper and Lower Nuttall Sandstone and the Upper and Lower Raleigh Sandstone. These units become less resistant to the southeast due to an increase in mica and feldspar content with in the sandstone members (Englund and others, 1977; Englund and others, 1982).

\section{Methodology}

The New River Gorge has several strip-mine benches, railroad grades, and road grades that provide an opportunity to assess denudation due to mass movement. Massmovement deposits can accumulate after maintenance of these benches and grades is discontinued. If the date of abandonment is known the benches and grades provides a valuable time line for assessing rates of mass movement. A denudation rate can be obtained by calculating the volume of mass-movement deposits on the bench or grade and dividing by the amount of time since maintenance was discontinued. Slope disturbance due to the construction of the grades and benches can artificially increase the frequency of mass movement. Therefore, these rates should be considered a maximum rate for mass-movement denudation under present-day climatic conditions in the gorge.

The Hinton and Bluestone formations are the least resistant of the four major rock units exposed in the gorge. The Pocahontas Formation is considered intermediate in resistance and the New River Formation is by far the most resistant unit in the gorge. Unfortunately, there are no grades or benches, within the New River Formation that meet the sampling criteria. Hence, data were collected only from the Pocahontas, Bluestone, and Hinton formations. Dates of abandonment for these road and railroad grades were obtained from National Park Service records. 
Sampling sites were selected based on their position in the stratigraphy of the New River Gorge. Each of the areas is located on a railroad or road grade with a known date of abandonment. Railroad and road grades were selected because they have relatively uniform dimensions and their transect across the observed formations meet the sampling criteria. Each sample area is $4.56 \mathrm{~km}$ in length and is divided into thirty, $152 \mathrm{~m}$ long sampling intervals. Using a grid system (figures 3-5), each interval was assigned a number from 1 to 30 . A random number generator was used to select seven sample intervals from the 30 possible at each sample area. Field data was collected at the selected intervals by measuring the volume of mass-movement deposits on the road or railroad grade.

The Pocahontas Formation data were obtained along a railroad grade from Dunloup Creek to the town of Minden in the Thurmond Quadrangle (figure 3). The Bluestone Formation data were obtained from a railroad grade near river level, starting near the mouth of Dunloup Creek to a point $4.56 \mathrm{~km}$ north of Dunloup Creek (figure 4). The National Park Service has converted both of these grades to hiking trails. Based on the condition of the mass-movement deposits, it appears that trail maintenance does not significantly disturb mass-movement deposits on these grades (figure 6). The Hinton Formation data were obtained from an abandoned road grade along the New River at Glade Creek to a point $4.56 \mathrm{~km}$ east of Glade Creek in the Prince and Meadow Creek Quadrangles (figure 5). This road grade is not a maintained trail and is overgrown with vegetation.

The mass-movement denudation rates are calculated using the following equation:

$$
\mathrm{Dm}=\mathrm{Tv} / \mathrm{Ya} / \mathrm{As}
$$




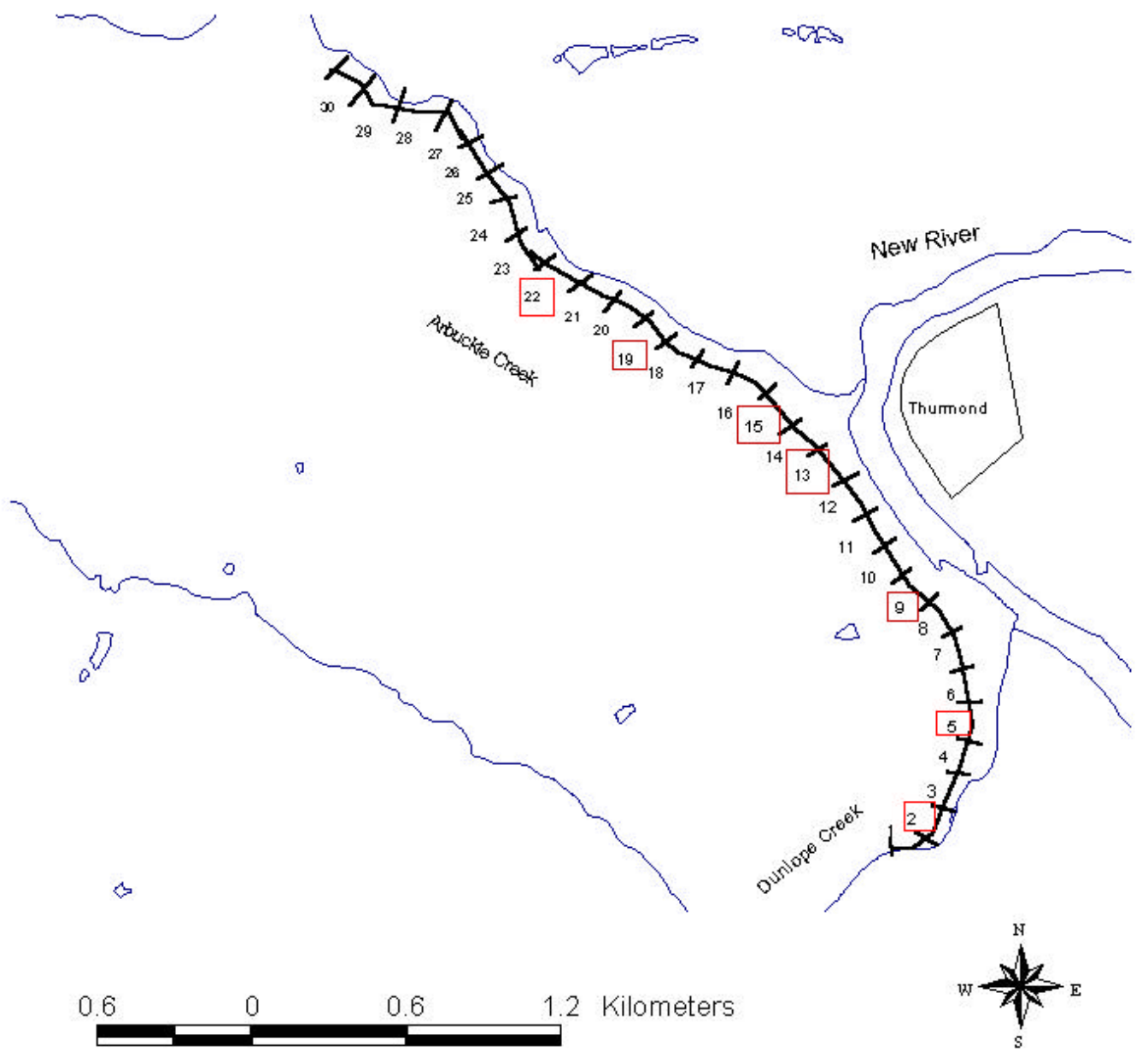

Figure 3: Map of Pocahontas Formation sampling section. Boxes indicate randomly selected sites. 


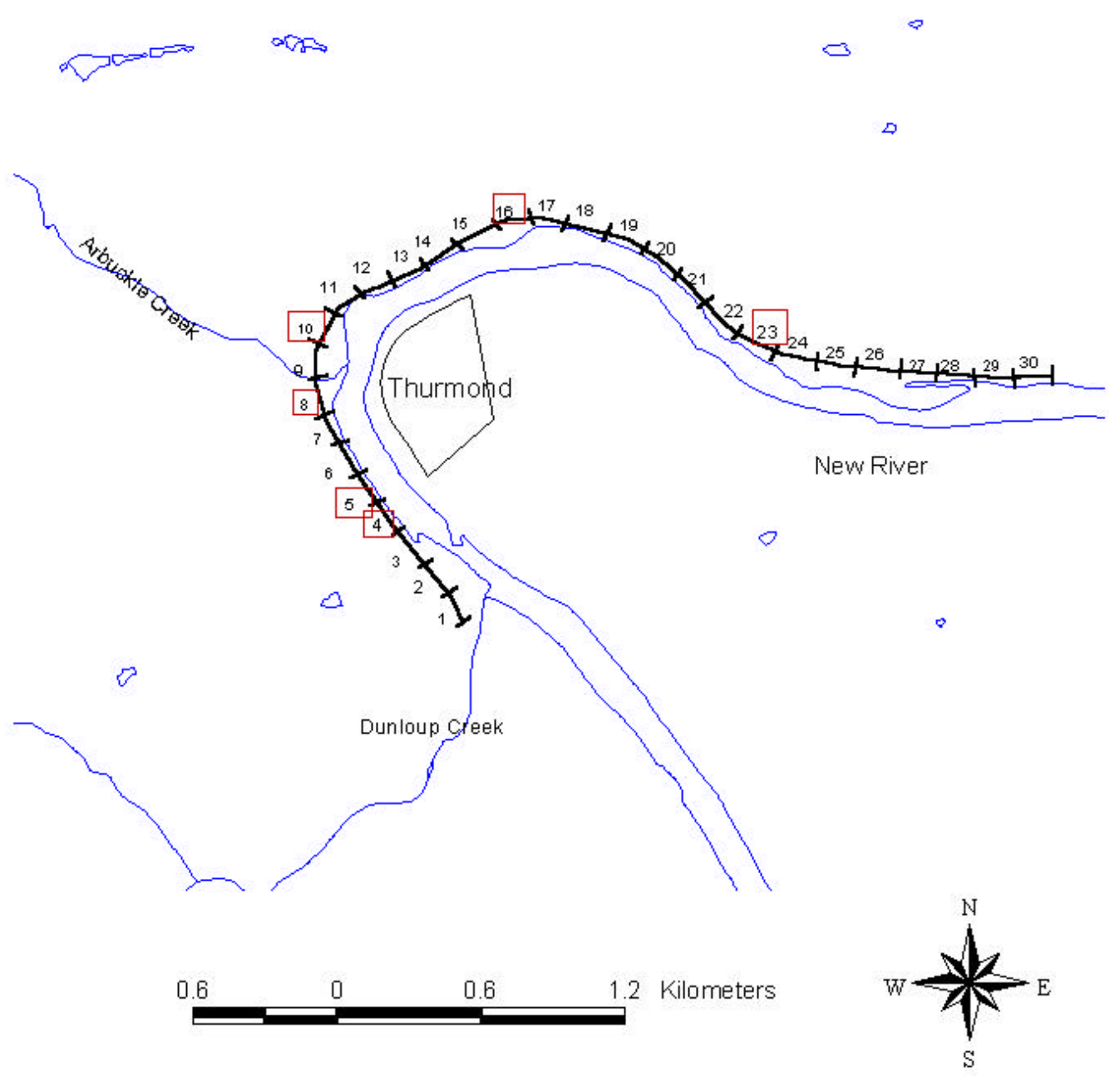

Figure 5: Map of Hinton Formation sampling section. Boxes indicate randomly selected sites. 


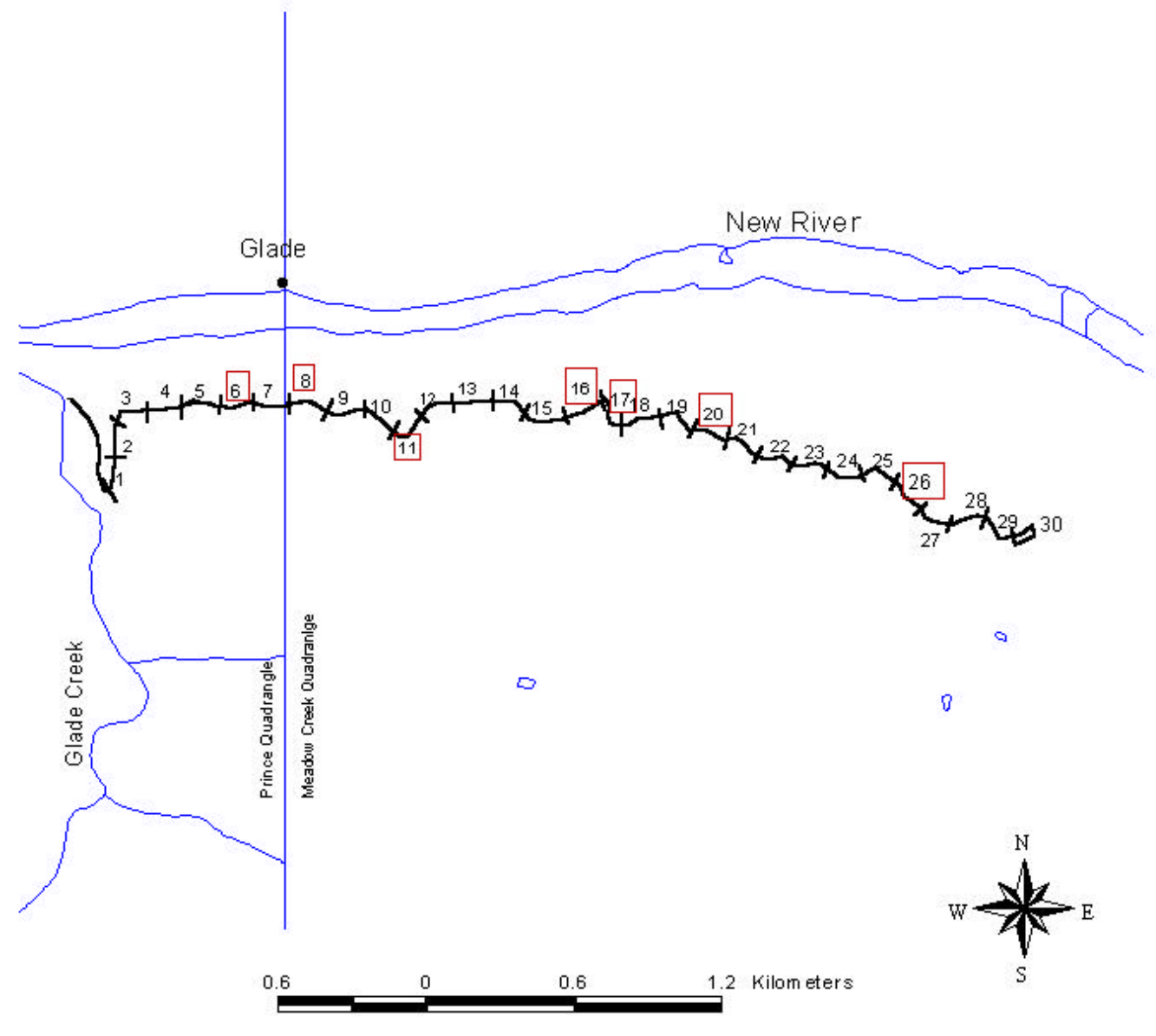

Figure 5: Map of Hinton Formation sampling section. Boxes indicate randomly selected sites. 


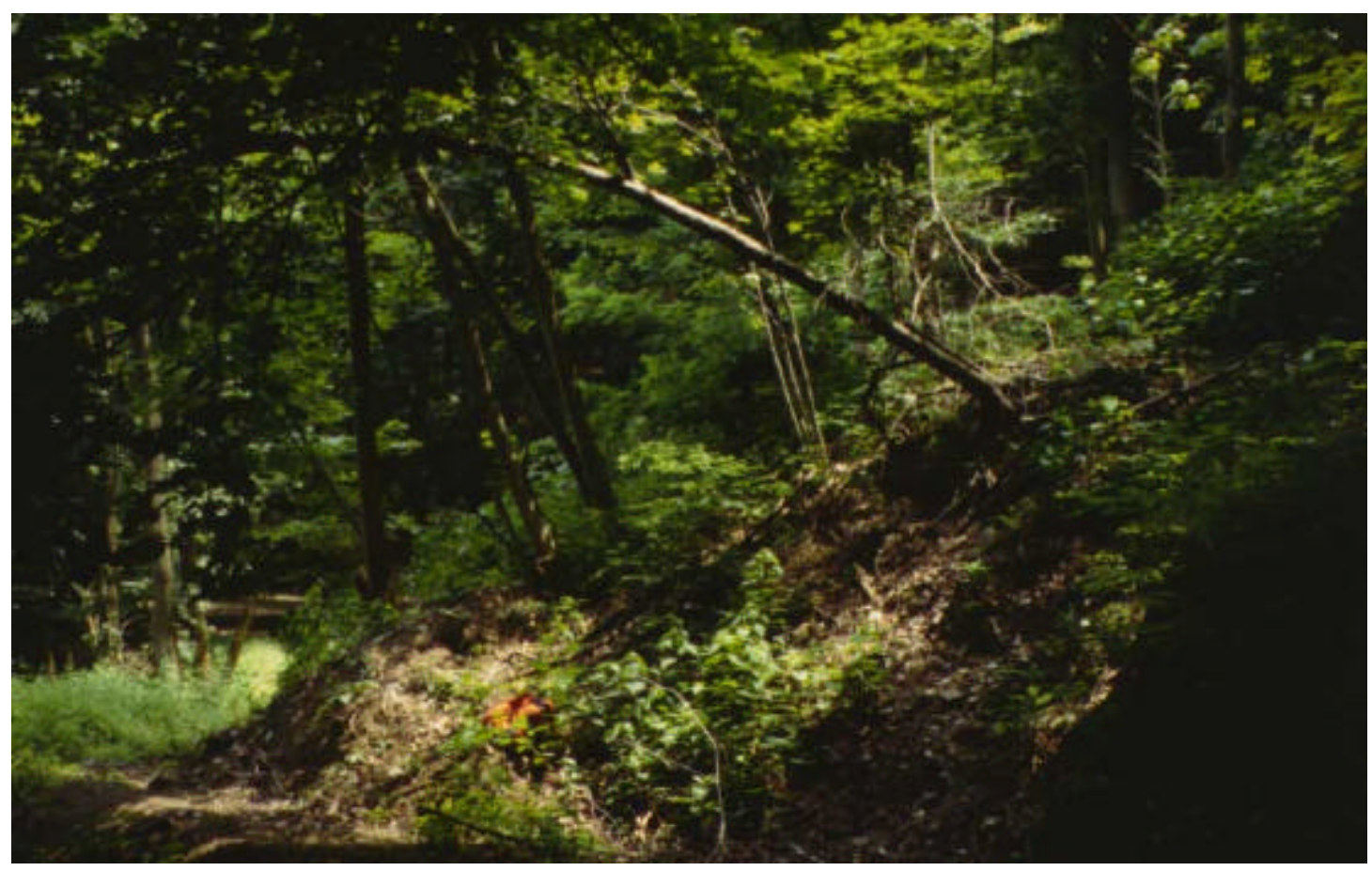

Figure 2 - 3: A debris slide in the Bluestone Formation sample section near Arbuckle Creek. This is railroad grade has been converted to a hiking trail, but maintenance has little impact of the deposit.

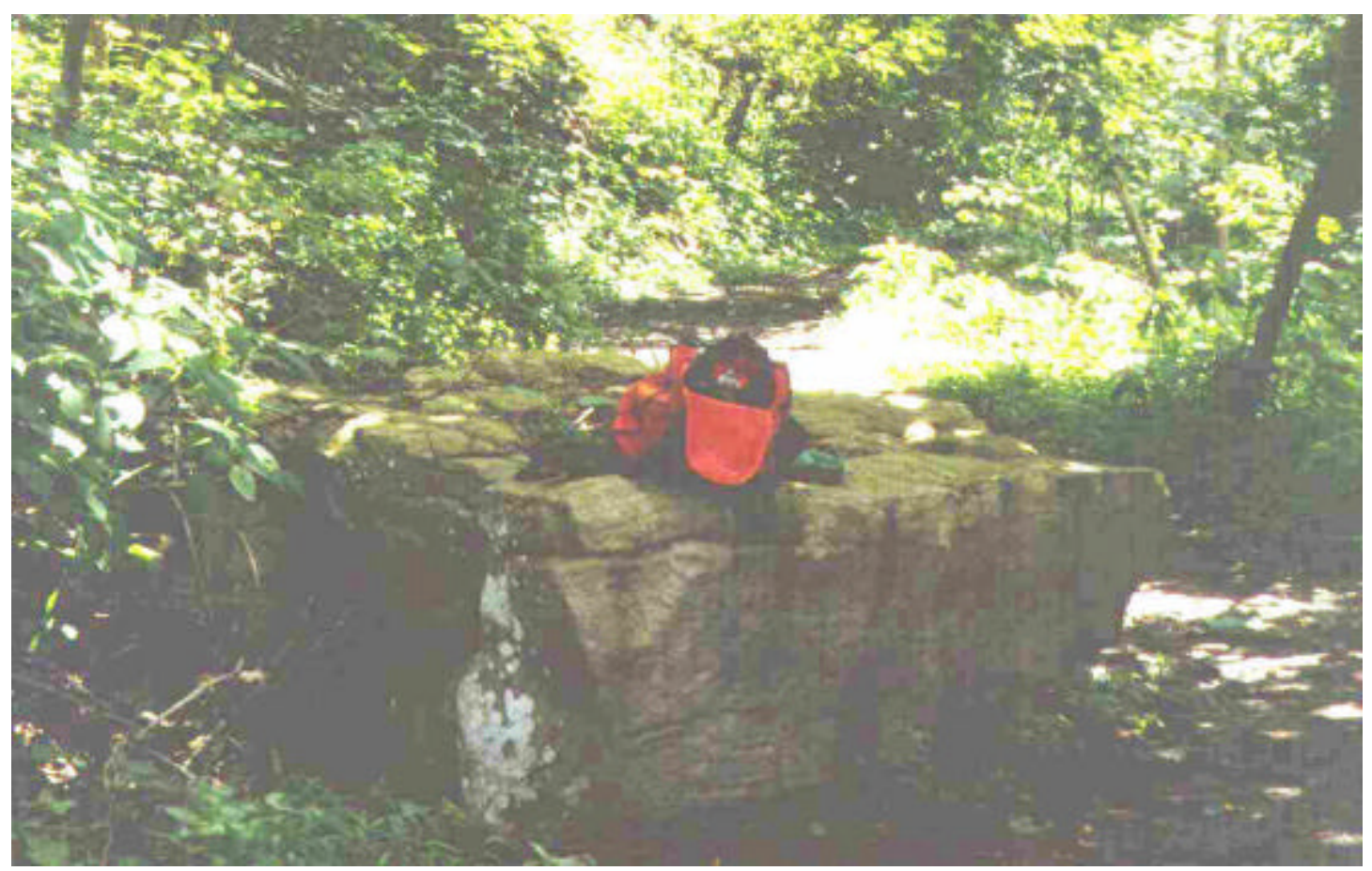

Figure 2 -4: A rock-fall boulder in the Pocahontas Formation sample section between Arbuckle and Dunloup Creeks. This railroad grade has been converted into a trail and maintenance has ha little impact on this boulder 
The variable Dm is mass-movement denudation rate in $\mathrm{m} / \mathrm{ma}$. The variable $\mathrm{Tv}$ is the sum of the total volume of mass-movement deposits. The variable Ya is the number of years since abandonment. The variable As is the surface area contributing to the deposits, calculated as the width of the sampling interval multiplied by the length of the slope from the grade to the top of the slope.

\section{Results}

The volume of material deposited on the road and railroad grades decreases up stratigraphic section from the Hinton to the Pocahontas formations. The Pocahontas Formation has the smallest calculated rate of denudation with $36.02 \mathrm{~m} / \mathrm{ma}$, followed by the Bluestone Formation with a calculated denudation rate of $56.45 \mathrm{~m} / \mathrm{ma}$. The Hinton Formation has the highest calculated rate of with $71.60 \mathrm{~m} / \mathrm{ma}$ (table1).

\begin{tabular}{|l|r|}
\hline Pocahontas River Formation & 135.61 \\
\hline Total amount of material measured $\left(\mathrm{m}^{3}\right)$ & 26 \\
\hline Years of abandonment & 144804 \\
\hline Area of scope $\left(\mathrm{m}^{2}\right)$ & $\mathbf{3 6 . 0 2}$ \\
\hline Rate of denudation in $(\mathrm{m} / \mathrm{ma})$ & 326.65 \\
\hline Bluestone Formation & 23 \\
\hline Total amount of material measured $\left(\mathrm{m}^{3}\right)$ & 251592 \\
\hline Years of abandonment & $\mathbf{5 6 . 4 5}$ \\
\hline Area of scope $\left(\mathrm{m}^{2}\right)$ & \\
\hline Rate of denudation $(\mathrm{m} / \mathrm{ma})$. & 411.69 \\
\hline Hinton Formation & 21 \\
\hline Total Amount of Material Measured in $\left(\mathrm{m}^{3}\right)$ & 390984 \\
\hline Years of Abandonment & $\mathbf{7 1 . 6 0}$ \\
\hline Area of scope $\left(\mathrm{m}^{2}\right)$ & \\
\hline Rate of denudation $(\mathrm{m} / \mathrm{ma})$ & \\
\hline
\end{tabular}

Table 2-1: Results from the mass-movement denudation 


\section{Discussion}

The decrease in denudation ascending the stratigraphic section from the Upper Mississippian Hinton Formation to the Lower Pennsylvanian Pocahontas Formation. The lithology of these formations is the most likely explanation for this trend. The Pocahontas Formation is comprised of quartz sandstone with lesser amounts of shale and coal, whereas the Hinton and Bluestone formations are more shale-dominated with less of quartz sandstone (Englund and others, 1977). Calculations from measured sections, (Hennen and others, 1919; Kerbs and Teets, 1916) near the sampling sites show the Pocahontas Formation consists of approximately $70 \%$ quartz sandstone. In contrast, the Bluestone and Hinton formations each consist of approximately $30 \%$ quartz sandstone.

This study estimates the mass-movement denudation rate to be between 36.02 $\mathrm{m} / \mathrm{ma}$ and $71.60 \mathrm{~m} / \mathrm{ma}$. The long-term denudation rate for the landscape can be no greater than the calculated denudation rate for the Pocahontas Formation, which serves as a resistant cap rock. The denudation rate for the Pocahontas is similar to the $36 \mathrm{~m} / \mathrm{ma}$ rate calculated by Dole and Stabler (1909) for the Southern Appalachians and the $27.3 \pm$ $4.5 \mathrm{~m} / \mathrm{ma}$ Quaternary down-cutting rate, calculated by Granger and others (1997) for the New River in southwestern Virginia.

An unexpected result of this study is the long-term regional, denudation and down-cutting rates are similar to the denudation rates calculated for disturbed slopes of the New River Gorge. In contrast, numerous other researchers have found that erosion rates from road related landslides are many times greater than those from undisturbed 
slopes (Swanson and Dyrness, 1975; McCashion and Rice, 1983; Schroeder and Brown, 1984; Amaranthus and others, 1985; Montgomery, 1994). Disturbed slopes, such as the grades in this study, would have a significantly higher rate of denudation than the average denudation rate for the entire landscape. The results from this study suggest the average denudation rates for the regional studies may also be a product of affected landscape disturbances.

Human influences maybe a reason why regional denudation rates are similar to the disturbed slopes of the New River Gorge. The regional studies by Dole and Stabler (1909) and Hack (1965) calculated erosion rates based on suspended and dissolved loads. The range in Anthropomorphic effects, such as agriculture, strip-mining, and urbanization, most likely influence these calculated rates. Anthropomorphic affects are exemplified by the work of Judson and Ritter (1964), who calculated denudation rates of $10 \mathrm{~m} / \mathrm{ma}$ for the Juniata River drainage basins, $20 \mathrm{~m} / \mathrm{ma}$ for the Delaware River, and 70 m/ma for the Schuykill River. The high denudation rate for the Schuykill River drainage basin reflects the presence of more strip mining and agriculture, and less forest cover than occurs in the other two drainage basins (Sevon, 1989).

Climate is an important consideration in comparing long-term denudation and down-cutting rates to the mass-movement rates measured in this study. Long- term down- cutting rate such as Granger and others (1997) average climatic influence over hundreds of thousands to millions of years. Denudation rates vary with climatic conditions. Under current climatic conditions, the present-day denudation rate may be significantly lower than long-term denudation rates. If the present day denudation rates are significantly less than the long-term denudation rate, the present day mass-movement 
rates calculated in this study represents what one would intuitively expect, increased mass-movement rates on disturbed slopes.

Another possible reason for the similarity of long-term denudation rates to massmovement rate is the absence of meteorological triggering events since the abandonment of these grades. The length of abandonment of the grades ranges from 21 to 26 years. Triggering events in the Appalachian Plateau are usually a combination of precipitation, antecedent moisture, and infiltration (Jacobson and Pomeroy, 1987). It is possible that there has not been a significant meteorological triggering event to produce the number of mass-movement events that would normally occur on these slopes over longer time intervals. If this were the case, this estimate of denudation rates would present an underestimation of the likely rate of denudation.

The basis for the similarity between the regional down-cutting rates, regional denudation rates, and mass-movement rate is probably complex combination of the factors outlined above. It is evident from this and other studies, that more work needs to be done to gain a better understanding of down-cutting and denudation rates and their true implications in the Central Appalachians. 


\section{References}

Amaranthus, M.P., Rice, R.M., Barr, N. R., Ziemer, 1985, Logging and forest roads related to increase debris slide in southwestern Oregon: Journal of Forestry, v. 83, p. 229-233.

Bartholomew, M.J., and Mills, H.H., 1991, Old courses of the New River: It's late Cenozoic migration and bedrock control inferred from high-level stream gravels, southwestern Virginia: Geological Society of America Bulletin, v. 103, p. 73-81.

Dole, R.B. and Stabler, H., 1909. Denudation, U.S. Geologic Survey, Water Supply Paper 234: p. 79-93.

Englund, K.J., Arndt, H.H., Henry, T.W., Meissner, C.R., Jr., Windolph, J.F., Jr., and Warlow, R.C., 1977, Geologic map of the New River Gorge Area, Fayette, Raleigh and Summers Counties, West Virginia: U.S. Geological Survey Open File Report OF-77-76 -A, Scale 1:50,000 with text.

Englund, K.J., Johnson, P.L., and Arndt, H.H., 1982, Geology of the New River Gorge, West Virginia, in New River Symposium Proceedings, May 6-8, 1982, Beckley West Virginia, p. 136-145.

Granger D.E., Kirchner, J.W., Finkel, R.C., 1997, Quaternary downcutting rate of the New River, Virginia measured from differential decay of cosmogenic ${ }^{26} \mathrm{Al}$ and ${ }^{10} \mathrm{Be}$ in cave-deposited alluvium, Geology, v. 25, no. 2, p. 107-110.

Hack, J.T., 1965, Geomorphology of the Shenadoah Valley, Virginia and West Virginia, and the origin of the residual ore deposits: U.S. Geologic Survey Professional Paper 484, p. B1-B17.

Hack, J.T., 1979, Rock control and tectonism - Their importance in shaping the Appalachian highlands: U.S. Geologic Survey Professional Paper 1126, p. B1B17.

Hennen, R.V. Teets, D.D., Jr., Tucker, R.C., and Hagen, A. M., 1919, Fayette County: West Virginia Geology Survey (County Report.), 1002p.

Houser, B.B., 1981, Erosional history of the New River, southern Appalachians: Erosional history of the New River, southern Appalachians: U.S. Geological Survey Open-File Report 81-771, 225p.

Jacobson, R.B., and Pomeroy, J.S., 1987, Slope failures in the Appalachian Plateau in Graf, W.L., ed., Geomorphic systems of North America: Boulder Colorado, Geological Society of America, p. 21-33. 
Judson, S. and Ritter, D.F., 1964, Rates of regional denudation in the United States: Journal of Geophysical Research, v. 69, p. 3395- 3401.

Krebs, C.E. and Teets, D.D.,1916, Raleigh County and the western portions of Mercer and Summers Counties: West Virginia Geologic Survey (County Report.), 778 p.

McCashion, J.D., and R.M. Rice, 1983, Erosion on logging road in Northwestern California: Journal of Forestry, v. 81, p. 1159-1163.

Montgomery, D.R., 1994, Road surface drainage, channel initiation and slope instability: Water Resources Research, v. 30, no. 6, p. 1925-1932.

Mills H.H., 1986, Possible differential uplift of New River terraces in southwestern Virginia: Neotectonics, v.1, p. 75-86.

Schroeder, W.L., and G.W. Brown, 1984, Debris torrents, precipitation, and roads in two coastal Oregon watersheds in Montgomery, D.R., Road surface drainage, channel initiation and slope instability: Water Resources Research, v. 30, no. 6, p. 19251932.

Schmidt, V.A., 1982, Magnetostratrigraphy of sediments in Mammoth Cave, Kentucky: Science, v. 217, p. 827-829.

Sevon, W.D., 1989, Erosion in the Juniata River Drainage Basin, Pennsylvania: Geomorphology, v.2, p. 303-318.

Swanson, F.J., and C.T, Dryness, 1975, Impact of clear-cutting and road construction on soil erosion by landslides in western Cascade Range, Oregon, Geology, v. 3, p. 393-396. 


\section{Appendices}

\begin{tabular}{|c|c|c|c|c|c|c|c|c|c|}
\hline Sandstone Member & & Nuttall & & Guyandot & & Raliegh & & Pineville & \\
\hline Location & & (x) axis & (y) axis & $(\mathrm{x})$ axis & (y) axis & (x) axis & (y) axis & (x) axis & (y) axis \\
\hline Kaymoor & & 5.18 & 13.11 & 7.62 & 6.10 & 10.67 & 1.37 & 3.66 & 4.57 \\
\hline & & 18.90 & 9.14 & 10.97 & 4.88 & 4.57 & 1.52 & 4.57 & 3.66 \\
\hline & & 20.12 & 13.11 & 9.75 & 4.27 & 5.49 & 1.83 & 5.49 & 2.44 \\
\hline & & 19.20 & 18.29 & 13.11 & 2.74 & 4.88 & 1.52 & 2.44 & 1.22 \\
\hline & & 18.29 & 13.11 & 7.31 & 4.57 & 6.10 & 1.22 & 3.66 & 1.22 \\
\hline & Mean & 16.34 & 13.35 & 9.75 & 4.51 & 6.34 & 1.49 & 19.81 & 13.11 \\
\hline & STD & 6.27 & 3.25 & 2.41 & 1.21 & 2.49 & 0.23 & 1.14 & 1.49 \\
\hline Fayette & & 12.19 & 6.10 & 11.89 & 3.05 & 7.31 & 4.57 & 5.49 & 1.22 \\
\hline & & 17.68 & 12.19 & 10.06 & 3.66 & 9.14 & 3.66 & 9.14 & 2.13 \\
\hline & & 13.72 & 18.29 & 13.72 & 2.44 & 11.89 & 4.27 & 6.40 & 2.44 \\
\hline & & 18.29 & 19.81 & 8.53 & 4.27 & 9.14 & 5.18 & 7.92 & 1.52 \\
\hline & & 14.93 & 16.76 & 9.45 & 2.74 & 8.53 & 1.98 & 5.49 & 1.22 \\
\hline & Mean & 15.36 & 14.63 & 10.73 & 3.23 & 9.20 & 3.93 & 6.89 & 1.71 \\
\hline & $\overline{\text { STD }}$ & 2.59 & 5.56 & 2.07 & 0.73 & 1.67 & 1.22 & 1.61 & 0.55 \\
\hline Fayette Station & & 14.63 & 24.38 & 3.66 & 0.91 & 12.80 & 0.91 & 10.97 & 3.05 \\
\hline & & 10.67 & 18.29 & 2.13 & 0.91 & 5.49 & 1.22 & 8.23 & 2.44 \\
\hline & & 13.41 & 10.67 & 4.57 & 0.91 & 9.14 & 1.52 & 9.14 & 1.83 \\
\hline & & 15.85 & 18.90 & 2.44 & 0.91 & 7.92 & 2.13 & 9.75 & 2.13 \\
\hline & & 11.89 & 12.80 & 2.13 & 1.22 & 7.62 & 2.13 & 8.23 & 2.74 \\
\hline & Mean & 13.29 & 17.01 & 2.99 & 0.98 & 8.59 & 1.58 & 9.27 & 2.44 \\
\hline & SDV & 2.07 & 5.42 & 1.09 & 0.14 & 2.70 & 0.55 & 1.15 & 0.48 \\
\hline Beauty & & 16.46 & 21.33 & & & & & & \\
\hline & & 21.64 & 17.68 & & & & & & \\
\hline & & 53.34 & 36.57 & & & & & & \\
\hline & & 21.03 & 25.91 & & & & & & \\
\hline & & 36.57 & 13.72 & & & & & & \\
\hline & & 36.57 & 22.86 & & & & & & \\
\hline & Mean & 37.12 & 27.61 & & & & & & \\
\hline & STD & 13.85 & 7.87 & & & & & & \\
\hline Short Creek & & 18.28 & 30.47 & & & & & & \\
\hline & & 36.57 & 36.57 & & & & & & \\
\hline & & 27.43 & 24.65 & & & & & & \\
\hline & & 24.35 & 27.43 & & & & & & \\
\hline & & 21.29 & 18.28 & & & & & & \\
\hline & Mean & 28.35 & 29.05 & & & & & & \\
\hline & STD & 7.90 & 10.05 & & & & & & \\
\hline
\end{tabular}

Appendix 1: Measurements of bedding and joint spacing of the major sandstone members of the New River Formation in the lower gorge study area. The variable y is the bed thickness in meters where as the variable $\mathrm{x}$ is spacing between joints in meters. 


\begin{tabular}{|c|c|c|c|c|c|c|}
\hline Station \# & $\begin{array}{c}\text { Failure } \\
\text { Orientation } \\
\text { (degrees) }\end{array}$ & $\begin{array}{l}\text { Area } \\
\left(\mathrm{m}^{2}\right)\end{array}$ & $\begin{array}{c}\text { Slope of } \\
\text { Deposit } \\
\text { (degrees) }\end{array}$ & Age & Material & $\begin{array}{c}\text { Type of } \\
\text { Movement }\end{array}$ \\
\hline 26 & 58 & 81586 & 29 & Prehistoric & Debris & Slide \\
\hline 40 & 149 & 74166 & 27 & Prehistoric & Debris & Complex \\
\hline 41 & 180 & 158355 & 28 & Prehistoric & Debris & Complex \\
\hline 42 & 152 & 132149 & 28 & Prehistoric & Debris & Complex \\
\hline 43 & 186 & 40317 & 31 & Prehistoric & Debris & Complex \\
\hline 44 & 166 & 36747 & 31 & Prehistoric & Debris & Complex \\
\hline 45 & 152 & 53876 & 25 & Prehistoric & Debris & Complex \\
\hline 46 & 187 & 53796 & 24 & Prehistoric & Debris & Complex \\
\hline 47 & 174 & 102407 & 23 & Prehistoric & Debris & Complex \\
\hline 48 & 196 & 72632 & 23 & Prehistoric & Debris & Complex \\
\hline 49 & 184 & 132149 & 25 & Prehistoric & Debris & Complex \\
\hline 70 & 211 & 71446 & 21 & Prehistoric & Debris & Slide \\
\hline 71 & 44 & 74349 & 28 & Prehistoric & Debris & Slide \\
\hline 72 & 241 & 68937 & 32 & Prehistoric & Debris & Slide \\
\hline 74 & 262 & 107730 & 27 & Prehistoric & Debris & Slide \\
\hline 75 & 239 & 58915 & 30 & Prehistoric & Debris & Slide \\
\hline 76 & 218 & 106323 & 33 & Prehistoric & Debris & Slide \\
\hline 77 & 226 & 122616 & 29 & Prehistoric & Debris & Slide \\
\hline 78 & 218 & 138828 & 30 & Prehistoric & Debris & Slide \\
\hline 79 & 247 & 166780 & 29 & Prehistoric & Debris & Slide \\
\hline 80 & 258 & 232748 & 30 & Prehistoric & Debris & Slide \\
\hline 81 & 330 & 27720 & 14 & Prehistoric & Debris & Flow \\
\hline 82 & 62 & 43199 & 31 & Prehistoric & Debris & Slide \\
\hline 85 & 52 & 22484 & 30 & Prehistoric & Debris & Slide \\
\hline 86 & 55 & 37380 & 30 & Prehistoric & Debris & Slide \\
\hline 87 & 62 & 43836 & 29 & Prehistoric & Debris & Slide \\
\hline 88 & 67 & 43671 & 31 & Prehistoric & Debris & Slide \\
\hline 89 & 80 & 52596 & 31 & Prehistoric & Debris & Slide \\
\hline 90 & 64 & 26964 & 33 & Prehistoric & Debris & Slide \\
\hline 92 & 48 & 57194 & 34 & Prehistoric & Debris & Slide \\
\hline 94 & 43 & 66293 & 31 & Prehistoric & Debris & Slide \\
\hline 95 & 43 & 50181 & 29 & Prehistoric & Debris & Slide \\
\hline 96 & 355 & 258648 & 32 & Prehistoric & Debris & Slide \\
\hline 97 & 15 & 94701 & 31 & Prehistoric & Debris & Slide \\
\hline 98 & 19 & 124430 & 32 & Prehistoric & Debris & Slide \\
\hline 99 & 35 & 49346 & 31 & Prehistoric & Debris & Slide \\
\hline 100 & 30 & 61734 & 31 & Prehistoric & Debris & Slide \\
\hline 102 & 116 & 49349 & 30 & Prehistoric & Debris & Slide \\
\hline 103 & 83 & 71620 & 32 & Prehistoric & Debris & Slide \\
\hline 104 & 85 & 53096 & 32 & Prehistoric & Debris & Slide \\
\hline 105 & 52 & 86490 & 15 & Prehistoric & Debris & Slide \\
\hline 106 & 15 & 44252 & 28 & Prehistoric & Debris & Flow \\
\hline
\end{tabular}

Appendix 2: Data on mapped mass-movement deposits in the lower gorge study area. 


\begin{tabular}{|c|c|c|c|c|c|c|}
\hline Station \# & $\begin{array}{c}\text { Failure } \\
\text { Orientation } \\
\text { (degrees) }\end{array}$ & $\begin{array}{l}\text { Area } \\
\left(\mathrm{m}^{2}\right)\end{array}$ & $\begin{array}{c}\text { Slope of } \\
\text { Deposit } \\
\text { (degrees) }\end{array}$ & Age & Material & $\begin{array}{c}\text { Type of } \\
\text { Movement }\end{array}$ \\
\hline 107 & 357 & 100774 & 24 & Prehistoric & Debris & Slide \\
\hline 108 & 71 & 47779 & 28 & Prehistoric & Debris & Slide \\
\hline 109 & 60 & 55002 & 28 & Prehistoric & Debris & Slide \\
\hline 143 & 15 & 167810 & 25 & Prehistoric & Debris & Slide \\
\hline 144 & 322 & 179747 & 29 & Prehistoric & Debris & Slide \\
\hline 145 & 5 & 109273 & 29 & Prehistoric & Debris & Slide \\
\hline 84 & 66 & 16982 & 31 & Historic & Debris & Slide \\
\hline 67 & 280 & 6142 & 31 & Historic & Debris & Slide \\
\hline 11 & 48 & 3610 & 32 & Historic & Debris & Slide \\
\hline 101 & 26 & 48439 & 30 & Historic & Debris & Slide \\
\hline 110 & 178 & 29803 & 35 & Historic & Debris & Slide \\
\hline $1 \mathrm{H}$ & 35 & 6114 & 26 & Historic & Debris & Slide \\
\hline 73 & 161 & 52424 & 35 & Prehistoric & Rock & Fall \\
\hline 34 & 187 & 19934 & 41 & Historic & Rock & Fall \\
\hline M1 & 45 & 13132 & 32 & Historic & Slide/Flow & Mine Spoil \\
\hline M2 & 50 & 13815 & 35 & Historic & Slide/Flow & Mine Spoil \\
\hline M3 & 355 & 13222 & 27 & Historic & Slide/Flow & Mine Spoil \\
\hline M4 & 5 & 5699 & 24 & Historic & Slide/Flow & Mine Spoil \\
\hline M5 & 177 & 38584 & 13 & Historic & Slide & Mine Spoil \\
\hline M6 & 267 & 3031 & 27 & Historic & Slide/Flow & Mine Spoil \\
\hline M7 & 157 & 32147 & 29 & Historic & Slide/Flow & Mine Spoil \\
\hline M8 & 157 & 5782 & 29 & Historic & Slide/Flow & Mine Spoil \\
\hline M9 & 83 & 3871 & 32 & Historic & Slide/Flow & Mine Spoil \\
\hline M10 & 90 & 3979 & 32 & Historic & Slide/Flow & Mine Spoil \\
\hline M11 & 207 & 7976 & 31 & Historic & Slide/Flow & Mine Spoil \\
\hline M12 & 39 & 11796 & 31 & Historic & Slide/Flow & Mine Spoil \\
\hline M13 & 67 & 10957 & 33 & Historic & Slide/Flow & Mine Spoil \\
\hline M14 & 209 & 15683 & 29 & Historic & Slide/Flow & Mine Spoil \\
\hline M15 & 112 & 4476 & 30 & Historic & Slide/Flow & Mine Spoil \\
\hline M16 & 159 & 4328 & 27 & Historic & Slide/Flow & Mine Spoil \\
\hline M17 & 257 & 8309 & 33 & Historic & Slide/Flow & Mine Spoil \\
\hline M18 & 108 & 32147 & 33 & Historic & Slide/Flow & Mine Spoil \\
\hline M19 & 103 & 7917 & 39 & Historic & Slide/Flow & Mine Spoil \\
\hline M20 & 123 & 1810 & 37 & Historic & Slide/Flow & Mine Spoil \\
\hline M21 & 129 & 3979 & 37 & Historic & Slide/Flow & Mine Spoil \\
\hline M22 & 177 & 1215 & 38 & Historic & Slide/Flow & Mine Spoil \\
\hline M23 & 198 & 1503 & 32 & Historic & Slide/Flow & Mine Spoil \\
\hline M24 & 322 & 1500 & 29 & Historic & Slide/Flow & Mine Spoil \\
\hline M25 & 220 & 1500 & 24 & Historic & Slide/Flow & Mine Spoil \\
\hline
\end{tabular}

Appendix 2, (continued) 


\begin{tabular}{|c|c|c|c|c|c|c|}
\hline Station \# & $\begin{array}{c}\text { Failure } \\
\text { Orientation } \\
\text { (degrees) }\end{array}$ & $\begin{array}{l}\text { Area } \\
\left(\mathrm{m}^{2}\right)\end{array}$ & $\begin{array}{c}\text { Slope of } \\
\text { Deposit } \\
\text { (degrees) }\end{array}$ & Age & Material & $\begin{array}{c}\text { Type of } \\
\text { Movement }\end{array}$ \\
\hline 3 & 5 & 175019 & 24 & Prehistoric & Debris & Complex \\
\hline 4 & 162 & 172611 & 24 & Prehistoric & Debris & Complex \\
\hline 6 & 177 & 220265 & 21 & Prehistoric & Debris & Complex \\
\hline 9 & 168 & 112328 & 23 & Prehistoric & Debris & Complex \\
\hline 22 & 38 & 88787 & 31 & Prehistoric & Debris & Complex \\
\hline 24 & 114 & 106630 & 34 & Prehistoric & Debris & Complex \\
\hline 53 & 64 & 171466 & 29 & Prehistoric & Debris & Complex \\
\hline 59 & 355 & 92643 & 28 & Prehistoric & Debris & Complex \\
\hline 68 & 126 & 114699 & 32 & Prehistoric & Debris & Complex \\
\hline 69 & 135 & 58785 & 34 & Prehistoric & Debris & Complex \\
\hline 70 & 101 & 131097 & 33 & Prehistoric & Debris & Complex \\
\hline 71 & 65 & 176522 & 31 & Prehistoric & Debris & Complex \\
\hline 72 & 53 & 141031 & 33 & Prehistoric & Debris & Complex \\
\hline 73 & 357 & 218501 & 26 & Prehistoric & Debris & Complex \\
\hline 74 & 25 & 108479 & 29 & Prehistoric & Debris & Complex \\
\hline 75 & 35 & 107109 & 31 & Prehistoric & Debris & Complex \\
\hline 77 & 30 & 111894 & 32 & Prehistoric & Debris & Complex \\
\hline 78 & 21 & 91972 & 31 & Prehistoric & Debris & Complex \\
\hline 121 & 346 & 130433 & 30 & Prehistoric & Debris & Complex \\
\hline 122 & 356 & 113722 & 28 & Prehistoric & Debris & Complex \\
\hline 123 & 311 & 127663 & 32 & Prehistoric & Debris & Complex \\
\hline 124 & 304 & 236920 & 22 & Prehistoric & Debris & Complex \\
\hline 125 & 314 & 166905 & 26 & Prehistoric & Debris & Complex \\
\hline 126 & 285 & 139350 & 24 & Prehistoric & Debris & Complex \\
\hline 127 & 172 & 80606 & 32 & Prehistoric & Debris & Complex \\
\hline 128 & 190 & 67932 & 30 & Prehistoric & Debris & Complex \\
\hline 129 & 193 & 82431 & 30 & Prehistoric & Debris & Complex \\
\hline 130 & 186 & 78442 & 28 & Prehistoric & Debris & Complex \\
\hline 131 & 213 & 68079 & 30 & Prehistoric & Debris & Complex \\
\hline 132 & 194 & 64219 & 30 & Prehistoric & Debris & Complex \\
\hline 133 & 180 & 12523 & 29 & Prehistoric & Debris & Complex \\
\hline 134 & 225 & 127039 & 25 & Prehistoric & Debris & Complex \\
\hline 135 & 204 & 60164 & 28 & Prehistoric & Debris & Complex \\
\hline 136 & 184 & 77134 & 26 & Prehistoric & Debris & Complex \\
\hline 137 & 205 & 44824 & 25 & Prehistoric & Debris & Complex \\
\hline 139 & 156 & 161507 & 22 & Prehistoric & Debris & Complex \\
\hline 140 & 185 & 140123 & 22 & Prehistoric & Debris & Complex \\
\hline 141 & 190 & 114219 & 22 & Prehistoric & Debris & Complex \\
\hline 142 & 174 & 120247 & 26 & Prehistoric & Debris & Complex \\
\hline 144 & 166 & 155133 & 24 & Prehistoric & Debris & Complex \\
\hline 145 & 158 & 99336 & 22 & Prehistoric & Debris & Complex \\
\hline 146 & 164 & 169431 & 20 & Prehistoric & Debris & Complex \\
\hline 147 & 166 & 58030 & 25 & Prehistoric & Debris & Complex \\
\hline
\end{tabular}

Appendix 3: Data on mapped mass-movement deposits in the middle gorge study area. 


\begin{tabular}{|c|c|c|c|c|c|c|}
\hline Station \# & $\begin{array}{c}\text { Failure } \\
\text { Orientation } \\
\text { (degrees) }\end{array}$ & $\begin{array}{l}\text { Area } \\
\left(\mathrm{m}^{2}\right)\end{array}$ & $\begin{array}{c}\text { Slope of } \\
\text { Deposit } \\
\text { (degrees) }\end{array}$ & Age & Material & $\begin{array}{c}\text { Type of } \\
\text { Movement }\end{array}$ \\
\hline 148 & 186 & 66540 & 31 & Prehistoric & Debris & Complex \\
\hline 149 & 188 & 43501 & 30 & Prehistoric & Debris & Complex \\
\hline 150 & 183 & 148086 & 23 & Prehistoric & Debris & Complex \\
\hline 151 & 157 & 130390 & 25 & Prehistoric & Debris & Complex \\
\hline 152 & 4 & 100523 & 21 & Prehistoric & Debris & Complex \\
\hline 153 & 357 & 85338 & 27 & Prehistoric & Debris & Complex \\
\hline 2 & 0 & 248711 & 27 & Prehistoric & Debris & Slide \\
\hline 5 & 230 & 430170 & 24 & Prehistoric & Debris & Slide \\
\hline 23 & 5 & 405145 & 26 & Prehistoric & Debris & Slide \\
\hline 32 & 182 & 57160 & 26 & Prehistoric & Debris & Slide \\
\hline 50 & 287 & 302179 & 28 & Prehistoric & Debris & Slide \\
\hline 51 & 332 & 165746 & 34 & Prehistoric & Debris & Slide \\
\hline 65 & 165 & 24424 & 27 & Prehistoric & Debris & Slide \\
\hline 66 & 1 & 537323 & 27 & Prehistoric & Debris & Slide \\
\hline 9 & 72 & 24909 & 19 & Prehistoric & Debris & Flow \\
\hline 21 & 352 & 140561 & 11 & Prehistoric & Debris & Flow \\
\hline 29 & 23 & 42994 & 14 & Prehistoric & Debris & Flow \\
\hline 30 & 74 & 211598 & 25 & Prehistoric & Debris & Flow \\
\hline 45 & 17 & 45726 & 22 & Prehistoric & Debris & Flow \\
\hline 48 & 262 & 128254 & 24 & Prehistoric & Debris & Flow \\
\hline 52 & 235 & 71599 & 23 & Prehistoric & Debris & Flow \\
\hline 143 & 204 & 40369 & 22 & Prehistoric & Debris & Flow \\
\hline 144 & 65 & 83114 & 29 & Prehistoric & Debris & Flow \\
\hline 8 & 181 & 11049 & 32 & Historic & Debris & Flow \\
\hline 25 & 130 & 2433 & 34 & Historic & Debris & Slide \\
\hline 31 & 83 & 1002 & 21 & Historic & Debris & Slide \\
\hline 49 & 180 & 8449 & 16 & Historic & Debris & Slide \\
\hline M2 & 208 & 3187 & 30 & Historic & Mine Spoil & Flow/Slide \\
\hline M3 & 22 & 7634 & 32 & Historic & Mine Spoil & Flow/Slide \\
\hline M4 & 67 & 2999 & 32 & Historic & Mine Spoil & Flow/Slide \\
\hline M5 & 89 & 1971 & 15 & Historic & Mine Spoil & Flow/Slide \\
\hline M6 & 261 & 10496 & 27 & Historic & Mine Spoil & Flow/Slide \\
\hline M7 & 86 & 2590 & 13 & Historic & Mine Spoil & Flow/Slide \\
\hline M8 & 199 & 2491 & 29 & Historic & Mine Spoil & Flow/Slide \\
\hline M9 & 33 & 3150 & 32 & Historic & Mine Spoil & Flow/Slide \\
\hline M10 & 307 & 33328 & 24 & Historic & Mine Spoil & Flow/Slide \\
\hline M11 & 350 & 2060 & 28 & Historic & Mine Spoil & Flow/Slide \\
\hline M12 & 261 & 1522 & 24 & Historic & Mine Spoil & Flow/Slide \\
\hline M13 & 28 & 3046 & 29 & Historic & Mine Spoil & Flow/Slide \\
\hline M14 & 85 & 6419 & 35 & Historic & Mine Spoil & Flow/Slide \\
\hline M15 & 159 & 3393 & 29 & Historic & Mine Spoil & Flow/Slide \\
\hline M16 & 173 & 2182 & 29 & Historic & Mine Spoil & Flow/Slide \\
\hline
\end{tabular}

Appendix 3, (continued) 


\begin{tabular}{|c|c|r|c|c|c|c|}
\hline Station \# & $\begin{array}{c}\text { Failure } \\
\text { Orientation } \\
\text { (degrees) }\end{array}$ & $\begin{array}{c}\text { Area } \\
\left(\mathrm{m}^{2}\right)\end{array}$ & $\begin{array}{c}\text { Slope of } \\
\text { Deposit } \\
\text { (degrees) }\end{array}$ & Age & Material & $\begin{array}{c}\text { Type of } \\
\text { Movement }\end{array}$ \\
\hline 1 & 59 & 8130 & 24 & Historic & Debris & Flow \\
\hline 16 & 147 & 110986 & 24 & Prehistoric & Debris & Slide \\
\hline 18 & 35 & 21935 & 13 & Prehistoric & Debris & Flow \\
\hline 55 & 311 & 3829 & 32 & Prehistoric & Debris & Slide \\
\hline 56 & 315 & 104839 & 32 & Prehistoric & Debris & Slide \\
\hline 57 & 66 & 75406 & 31 & Prehistoric & Debris & Slide \\
\hline 58 & 82 & 100209 & 31 & Prehistoric & Debris & Slide \\
\hline 59 & 85 & 122427 & 30 & Prehistoric & Debris & Slide \\
\hline 60 & 25 & 105217 & 24 & Prehistoric & Debris & Slide \\
\hline 61 & 35 & 108317 & 19 & Prehistoric & Debris & Slide \\
\hline 62 & 42 & 147274 & 20 & Prehistoric & Debris & Slide \\
\hline 63 & 76 & 287293 & 22 & Prehistoric & Debris & Slide \\
\hline
\end{tabular}

Appendix 4: Data on mapped mass-movement deposits in the upper gorge study area. 


\begin{tabular}{|c|c|c|c|c|c|c|}
\hline Study Area & Upper Gorge & \% of Total & Middle Gorge & $\%$ of Total & Lower Gorge & $\%$ of Total \\
\hline Degree of Slope & Frequency & Frequency & Frequency & Frequency & Frequency & Frequency \\
\hline 0 & 3517 & 8.17 & 1669 & 7.46 & 366 & 4.43 \\
\hline 1 & 260 & 0.60 & 82 & 0.37 & 20 & 0.24 \\
\hline 2 & 424 & 0.99 & 108 & 0.48 & 27 & 0.33 \\
\hline 3 & 571 & 1.33 & 147 & 0.66 & 58 & 0.70 \\
\hline 4 & 598 & 1.39 & 128 & 0.57 & 53 & 0.64 \\
\hline 5 & 545 & 1.27 & 157 & 0.70 & 45 & 0.55 \\
\hline 6 & 898 & 2.09 & 211 & 0.94 & 55 & 0.67 \\
\hline 7 & 628 & 1.46 & 163 & 0.73 & 34 & 0.41 \\
\hline 8 & 1051 & 2.44 & 216 & 0.97 & 72 & 0.87 \\
\hline 9 & 779 & 1.81 & 211 & 0.94 & 60 & 0.73 \\
\hline 10 & 1095 & 2.54 & 260 & 1.16 & 52 & 0.63 \\
\hline 11 & 1059 & 2.46 & 274 & 1.22 & 61 & 0.74 \\
\hline 12 & 1129 & 2.62 & 300 & 1.34 & 51 & 0.62 \\
\hline 13 & 1428 & 3.32 & 311 & 1.39 & 61 & 0.74 \\
\hline 14 & 1482 & 3.44 & 359 & 1.60 & 89 & 1.08 \\
\hline 15 & 1833 & 4.26 & 420 & 1.88 & 84 & 1.02 \\
\hline 16 & 1381 & 3.21 & 401 & 1.79 & 75 & 0.91 \\
\hline 17 & 1967 & 4.57 & 492 & 2.20 & 115 & 1.39 \\
\hline 18 & 1844 & 4.28 & 486 & 2.17 & 123 & 1.49 \\
\hline 19 & 1512 & 3.51 & 422 & 1.89 & 105 & 1.27 \\
\hline 20 & 2038 & 4.74 & 631 & 2.82 & 178 & 2.16 \\
\hline 21 & 1921 & 4.46 & 698 & 3.12 & 222 & 2.69 \\
\hline 22 & 1578 & 3.67 & 585 & 2.61 & 181 & 2.19 \\
\hline 23 & 1790 & 4.16 & 850 & 3.80 & 233 & 2.82 \\
\hline 24 & 1546 & 3.59 & 768 & 3.43 & 274 & 3.32 \\
\hline 25 & 1637 & 3.80 & 924 & 4.13 & 361 & 4.37 \\
\hline 26 & 1279 & 2.97 & 910 & 4.07 & 372 & 4.51 \\
\hline 27 & 1196 & 2.78 & 893 & 3.99 & 367 & 4.45 \\
\hline 28 & 1141 & 2.65 & 1012 & 4.52 & 488 & 5.91 \\
\hline 29 & 837 & 1.94 & 787 & 3.52 & 426 & 5.16 \\
\hline 30 & 780 & 1.81 & 874 & 3.91 & 474 & 5.74 \\
\hline 31 & 733 & 1.70 & 1057 & 4.72 & 534 & 6.47 \\
\hline 32 & 507 & 1.18 & 882 & 3.94 & 543 & 6.58 \\
\hline 33 & 454 & 1.05 & 891 & 3.98 & 493 & 5.97 \\
\hline 34 & 372 & 0.86 & 817 & 3.65 & 427 & 5.17 \\
\hline 35 & 275 & 0.64 & 799 & 3.57 & 352 & 4.27 \\
\hline 36 & 197 & 0.46 & 565 & 2.53 & 236 & 2.86 \\
\hline 37 & 149 & 0.35 & 368 & 1.64 & 162 & 1.96 \\
\hline 38 & 106 & 0.25 & 278 & 1.24 & 110 & 1.33 \\
\hline 39 & 78 & 0.18 & 196 & 0.88 & 70 & 0.85 \\
\hline 40 & 62 & 0.14 & 121 & 0.54 & 55 & 0.67 \\
\hline 41 & 50 & 0.12 & 103 & 0.46 & 30 & 0.36 \\
\hline 42 & 31 & 0.07 & 66 & 0.29 & 19 & 0.23 \\
\hline 43 & 41 & 0.10 & 49 & 0.22 & 9 & 0.11 \\
\hline 44 & 23 & 0.05 & 33 & 0.15 & 6 & 0.07 \\
\hline
\end{tabular}

Appendix 5: Combined slope data for the 3 study areas. Frequency is the number of $30 \mathrm{~m}$ by $30 \mathrm{~m}$ cells generated in slope calculation using USGS 7.5' digital elevation models. 


\begin{tabular}{|c|c|c|c|c|c|c|}
\hline Study Area & Upper Gorge & $\%$ of Total & Middle Gorge & $\%$ of Total & Lower Gorge & $\%$ of Total \\
\hline Degree of Slope & Frequency & Frequency & Frequency & Frequency & Frequency & Frequency \\
\hline 45 & 21 & 0.05 & 28 & 0.13 & 6 & 0.07 \\
\hline 46 & 23 & 0.05 & 23 & 0.10 & 6 & 0.07 \\
\hline 47 & 18 & 0.04 & 13 & 0.06 & 5 & 0.06 \\
\hline 48 & 17 & 0.04 & 33 & 0.15 & 1 & 0.01 \\
\hline 49 & 12 & 0.03 & 16 & 0.07 & 4 & 0.05 \\
\hline 50 & 17 & 0.04 & 18 & 0.08 & 1 & 0.01 \\
\hline 51 & 12 & 0.03 & 15 & 0.07 & 1 & 0.01 \\
\hline 52 & 11 & 0.03 & 26 & 0.12 & 1 & 0.01 \\
\hline 53 & 9 & 0.02 & 11 & 0.05 & 0 & 0.00 \\
\hline 54 & 11 & 0.03 & 14 & 0.06 & 0 & 0.00 \\
\hline 55 & 5 & 0.01 & 17 & 0.08 & 0 & 0.00 \\
\hline 56 & 13 & 0.03 & 11 & 0.05 & 0 & 0.00 \\
\hline 57 & 6 & 0.01 & 5 & 0.02 & 0 & 0.00 \\
\hline 58 & 12 & 0.03 & 11 & 0.05 & 0 & 0.00 \\
\hline 59 & 3 & 0.01 & 12 & 0.05 & 0 & 0.00 \\
\hline 60 & 8 & 0.02 & 4 & 0.02 & 0 & 0.00 \\
\hline 61 & 7 & 0.02 & 7 & 0.03 & 0 & 0.00 \\
\hline 62 & 4 & 0.01 & 14 & 0.06 & 0 & 0.00 \\
\hline 63 & 2 & 0.00 & 13 & 0.06 & 0 & 0.00 \\
\hline 64 & 5 & 0.01 & 20 & 0.09 & 0 & 0.00 \\
\hline 67 & 1 & 0.00 & 17 & 0.08 & 0 & 0.00 \\
\hline 68 & 0 & 0.00 & 21 & 0.09 & 0 & 0.00 \\
\hline 69 & 0 & 0.00 & 14 & 0.06 & 0 & 0.00 \\
\hline 70 & 0 & 0.00 & 10 & 0.04 & 0 & 0.00 \\
\hline 71 & 0 & 0.00 & 8 & 0.04 & 0 & 0.00 \\
\hline 72 & 0 & 0.00 & 6 & 0.03 & 0 & 0.00 \\
\hline 73 & 0 & 0.00 & 2 & 0.01 & 0 & 0.00 \\
\hline 74 & 0 & 0.00 & 3 & 0.01 & 0 & 0.00 \\
\hline 75 & 0 & 0.00 & 2 & 0.01 & 0 & 0.00 \\
\hline 76 & 0 & 0.00 & 2 & 0.01 & 0 & 0.00 \\
\hline 77 & 0 & 0.00 & 2 & 0.01 & 0 & 0.00 \\
\hline 78 & 0 & 0.00 & 2 & 0.01 & 0 & 0.00 \\
\hline 79 & 0 & 0.00 & 1 & 0.00 & 0 & 0.00 \\
\hline 80 & 0 & 0.00 & 0 & 0.00 & 0 & 0.00 \\
\hline 81 & 0 & 0.00 & 1 & 0.00 & 0 & 0.00 \\
\hline Sum & 43039 & 100.00 & 22376 & 100.00 & 8253 & 100.00 \\
\hline
\end{tabular}

Appendix 5, (continued) 


\begin{tabular}{|c|c|c|c|c|c|c|c|}
\hline & & & & & & Total & Area of \\
\hline Station \# & Type of Movement & Length $(\mathrm{m})$ & Width (m) & Depth (m) & Volume $\left(\mathrm{m}^{3}\right)$ & Volume $\left(\mathrm{m}^{3}\right)$ & Scope $\left(m^{2}\right)$ \\
\hline 2 & No Mass Movement & & & & & & \\
\hline \multirow{8}{*}{5} & Rock fall (8) & 0.91 & 0.61 & 0.30 & 0.17 & & \\
\hline & 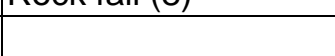 & 0.91 & 0.61 & 0.23 & 0.13 & & \\
\hline & & 1.07 & 0.69 & 0.46 & 0.33 & & \\
\hline & & 0.76 & 0.46 & 0.30 & 0.11 & & \\
\hline & & 0.91 & 0.61 & 0.23 & 0.13 & & \\
\hline & & 0.91 & 0.61 & 0.30 & 0.17 & & \\
\hline & & 0.76 & 0.46 & 0.30 & 0.11 & & \\
\hline & & 0.76 & 0.46 & 0.30 & 0.11 & 1.25 & 410520 \\
\hline & & & & & & & \\
\hline \multirow[t]{15}{*}{10} & Rock fall (11) & 0.61 & 0.46 & 0.46 & 0.13 & & \\
\hline & & 1.22 & 0.76 & 0.30 & 0.28 & & \\
\hline & & 1.22 & 0.46 & 0.46 & 0.25 & & \\
\hline & & 0.61 & 0.61 & 0.46 & 0.17 & & \\
\hline & & 1.22 & 0.61 & 0.30 & 0.23 & & \\
\hline & & 1.07 & 0.76 & 0.46 & 0.37 & & \\
\hline & & 1.52 & 0.61 & 0.61 & 0.57 & & \\
\hline & & 1.07 & 0.76 & 0.61 & 0.50 & & \\
\hline & & 0.61 & 0.30 & 0.61 & 0.11 & & \\
\hline & & 0.61 & 0.30 & 0.30 & 0.06 & & \\
\hline & & 1.22 & 1.07 & 0.76 & 0.99 & & \\
\hline & & 0.76 & 0.46 & 0.46 & 0.16 & & \\
\hline & Debris Slide & 2.74 & 1.52 & 0.46 & 1.91 & & \\
\hline & & & & & & 5.73 & 24948.00 \\
\hline & & & & & & & \\
\hline \multirow[t]{16}{*}{13} & Debris Slide & 4.57 & 3.05 & 0.30 & 4.25 & & \\
\hline & Debris Slide & 5.49 & 2.44 & 0.61 & 8.15 & & \\
\hline & Debris Slide & 3.66 & 1.68 & 0.61 & 3.74 & & \\
\hline & Debris Slide & 2.74 & 1.52 & 0.76 & 3.19 & & \\
\hline & & & & & & & \\
\hline & Rock fall (17) & 1.07 & 0.91 & 0.46 & 0.45 & & \\
\hline & & 0.61 & 0.46 & 0.46 & 0.13 & & \\
\hline & & 0.91 & 0.46 & 0.30 & 0.13 & & \\
\hline & & 1.07 & 0.46 & 0.46 & 0.22 & & \\
\hline & & 0.46 & 0.46 & 0.46 & 0.10 & & \\
\hline & & 0.61 & 0.46 & 0.30 & 0.08 & & \\
\hline & & 1.22 & 0.76 & 0.30 & 0.28 & & \\
\hline & & 1.22 & 0.91 & 0.61 & 0.68 & & \\
\hline & & 1.22 & 0.91 & 0.46 & 0.51 & & \\
\hline & & 1.07 & 0.76 & 0.61 & 0.50 & & \\
\hline & & 1.07 & 0.46 & 0.46 & 0.22 & & \\
\hline
\end{tabular}

Appendix 6: Data for deudation rates due to mass movement for the Pocahontas Formation from Dunloup Creek to Mindon along railroad grade paralleling Arbuckle Creek. 


\begin{tabular}{|c|c|c|c|c|c|c|c|}
\hline & & & & & & Total & Area of \\
\hline \multirow[t]{7}{*}{ Station \# } & Type of Movement & Length (m) & Width (m) & Depth (m) & Volume $\left(\mathrm{m}^{3}\right)$ & Volume $\left(\mathrm{m}^{3}\right)$ & Scope $\left(m^{2}\right)$ \\
\hline & & 0.61 & 0.46 & 0.46 & 0.13 & & \\
\hline & & 0.76 & 0.46 & 0.46 & 0.16 & & \\
\hline & & 0.91 & 0.30 & 0.23 & 0.06 & & \\
\hline & & 1.37 & 0.91 & 0.46 & 0.57 & & \\
\hline & & 0.76 & 0.76 & 0.30 & 0.18 & & \\
\hline & & & & & & 23.72 & 25080 \\
\hline & & & & & & & \\
\hline \multirow[t]{6}{*}{15} & Debris Slide & 4.88 & 1.52 & 0.30 & 2.27 & & \\
\hline & Debris Slide & 3.05 & 1.22 & 0.61 & 2.27 & & \\
\hline & Debris Slide & 1.37 & 1.83 & 0.76 & 1.91 & & \\
\hline & Debris Slide & 2.29 & 1.22 & 0.46 & 1.27 & & \\
\hline & & & & & & 7.72 & 20724 \\
\hline & & & & & & & \\
\hline \multirow[t]{9}{*}{19} & Rock fall (3) & 1.22 & 0.91 & 0.15 & 0.17 & & \\
\hline & & 0.91 & 0.61 & 0.15 & 0.08 & & \\
\hline & & 0.91 & 0.30 & 0.30 & 0.08 & & \\
\hline & & & & & & & \\
\hline & Debris Slide & 6.40 & 1.52 & 0.30 & 2.97 & & \\
\hline & & 6.40 & 1.52 & 0.46 & 4.46 & & \\
\hline & & 2.74 & 1.22 & 0.46 & 1.53 & & \\
\hline & & 3.66 & 0.91 & 0.30 & 1.02 & & \\
\hline & & & & & & 9.98 & 20064 \\
\hline \multirow{9}{*}{22} & Dehris Slide & 1554 & 305 & 076 & 3610 & & \\
\hline & Devis silut & \begin{tabular}{|l|} 
\\
2.74
\end{tabular} & 0.91 & 0.30 & $\begin{array}{r}0.10 \\
0.76\end{array}$ & & \\
\hline & & 2.74 & 1.22 & 0.33 & 1.10 & & \\
\hline & & 14.63 & 5.49 & 0.61 & 48.92 & & \\
\hline & & & & & & 86.88 & 12936 \\
\hline & & & & & & & \\
\hline & \multicolumn{4}{|l|}{ Total } & & 135.61 & 144804 \\
\hline & \multicolumn{4}{|c|}{ Number of Years of Abandonment } & & & 26 \\
\hline & \multicolumn{4}{|c|}{ Rate of Denudation in $\mathrm{m} /$ million Years } & & & 36.02 \\
\hline
\end{tabular}

Appendix 6: Continued 


\begin{tabular}{|c|c|c|c|c|c|c|c|}
\hline & & & & & & Total & Area of \\
\hline Station \# & Type of Movement & Length $(\mathrm{m})$ & Width $(m)$ & Depth (m) & Volume $\left(\mathrm{m}^{3}\right)$ & Volume $\left(\mathrm{m}^{3}\right)$ & Scope $\left(m^{2}\right)$ \\
\hline 4 & No Mass Movement & & & & & & \\
\hline & & & & & & & \\
\hline 5 & Debris Slide & 9.14 & 1.83 & 1.22 & 10.19 & & \\
\hline & Rock fall (2) & 0.76 & 0.61 & 0.30 & 0.14 & & \\
\hline & & 0.61 & 0.46 & 0.30 & 0.08 & 10.42 & 35640 \\
\hline & & & & & & & \\
\hline 8 & Rock fall (21) & 0.76 & 0.61 & 0.46 & 0.21 & & \\
\hline & & 1.22 & 0.91 & 0.61 & 0.68 & & \\
\hline & & 0.76 & 0.76 & 0.61 & 0.35 & & \\
\hline & & 1.07 & 0.91 & 0.61 & 0.59 & & \\
\hline & & 1.22 & 1.07 & 0.61 & 0.79 & & \\
\hline & & 1.22 & 0.61 & 0.46 & 0.34 & & \\
\hline & & 1.22 & 0.91 & 0.61 & 0.68 & & \\
\hline & & 1.07 & 0.76 & 0.46 & 0.37 & & \\
\hline & & 0.61 & 0.61 & 0.61 & 0.23 & & \\
\hline & & 1.22 & 1.07 & 0.61 & 0.79 & & \\
\hline & & 0.91 & 0.76 & 0.23 & 0.16 & & \\
\hline & & 0.91 & 0.61 & 0.61 & 0.34 & & \\
\hline & & 0.91 & 0.61 & 0.46 & 0.25 & & \\
\hline & & 0.91 & 0.61 & 0.46 & 0.25 & & \\
\hline & & 1.22 & 0.91 & 0.76 & 0.85 & & \\
\hline & & 1.83 & 0.91 & 0.61 & 1.02 & & \\
\hline & & 1.22 & 0.91 & 0.61 & 0.68 & & \\
\hline & & 0.91 & 0.61 & 0.46 & 0.25 & & \\
\hline & & 1.22 & 0.91 & 0.61 & 0.68 & & \\
\hline & & 1.07 & 0.61 & 0.61 & 0.40 & & \\
\hline & & 1.22 & 0.91 & 0.23 & 0.25 & & \\
\hline & Debris Slide & 2.74 & 0.91 & 0.61 & 0.76 & & \\
\hline & Debris Slide & 16.76 & 5.49 & 0.91 & 42.06 & 53.01 & 32604 \\
\hline 10 & Debris Slide & 2.44 & 1.52 & 1.22 & 2.27 & 2.27 & 47520 \\
\hline & & & & & & & \\
\hline 15 & Debris Slide & 9.14 & 4.57 & 0.91 & 19.11 & & \\
\hline & & 8.23 & 2.44 & 1.52 & 15.29 & 34.40 & 45936 \\
\hline & & & & & & & \\
\hline 16 & Rock fall (4) & 1.37 & 0.91 & 0.30 & 0.38 & & \\
\hline & & 0.61 & 0.46 & 0.30 & 0.08 & & \\
\hline & & 0.91 & 0.76 & 0.30 & 0.21 & & \\
\hline & & 1.22 & 0.76 & 0.30 & 0.14 & & \\
\hline & Debris Slide & 3.66 & 1.53 & 0.61 & 1.71 & & \\
\hline & & 2.44 & 1.83 & 1.07 & 2.38 & 4.91 & 46464 \\
\hline 23 & Rock Slides & 914 & 6.40 & 122 & 3567 & & \\
\hline & nock sildes & 9.14 & 0.40 & $1 .<<$ & 35.67 & & \\
\hline
\end{tabular}

Appendix 7: Data for deudation rates due to mass movement for the Bluestone Formation along abandoned railroad grade from Dunloup Creek to $4.56 \mathrm{~km}$ downstream. 


\begin{tabular}{|c|c|c|c|c|c|c|c|}
\hline & & & & & & Total & Area of \\
\hline \multirow[t]{18}{*}{ Station \# } & Type of Movement & Length $(\mathrm{m})$ & Width (m) & Depth (m) & Volume $\left(\mathrm{m}^{3}\right)$ & Volume $\left(\mathrm{m}^{3}\right)$ & Scope $\left(m^{2}\right)$ \\
\hline & & 10.06 & 6.10 & 0.76 & 23.36 & & \\
\hline & & 3.66 & 3.05 & 1.22 & 6.80 & & \\
\hline & & 23.77 & 6.10 & 1.83 & 132.50 & & \\
\hline & & 4.57 & 1.83 & 1.22 & 5.10 & & \\
\hline & Rock fall (8) & 1.37 & 0.91 & 0.61 & 0.38 & & \\
\hline & & 0.61 & 0.61 & 0.30 & 0.06 & & \\
\hline & & 1.07 & 0.91 & 0.61 & 0.30 & & \\
\hline & & 0.91 & 0.61 & 0.30 & 0.08 & & \\
\hline & & 0.61 & 0.30 & 0.30 & 0.03 & & \\
\hline & & 1.22 & 0.30 & 0.23 & 0.04 & & \\
\hline & & 1.83 & 1.22 & 0.91 & 1.02 & & \\
\hline & & 3.66 & 2.44 & 3.66 & 16.31 & 185.97 & 43428 \\
\hline & & & & & & & \\
\hline & & & & & & & \\
\hline & \multicolumn{4}{|l|}{ Total } & & 326.65 & 251592 \\
\hline & \multicolumn{4}{|l|}{$\begin{array}{l}\text { Number of Years of } \\
\text { Abandonment }\end{array}$} & & & 23 \\
\hline & \multicolumn{4}{|c|}{$\begin{array}{l}\text { Rate of Denudation in } \mathrm{m} / \text { million } \\
\text { years }\end{array}$} & & & 56.45 \\
\hline
\end{tabular}

Appendix 7: Continued: 


\begin{tabular}{|c|c|c|c|c|c|c|c|}
\hline & & & & & & Total & Area of \\
\hline Station \# & Type of Movement & Length $(\mathrm{m})$ & Width (m) & Depth $(\mathrm{m})$ & Volume $\left(\mathrm{m}^{3}\right)$ & Volume $\left(\mathrm{m}^{3}\right)$ & Scope $\left(m^{2}\right)$ \\
\hline \multirow[t]{3}{*}{6} & Debris Slide & 16.15 & 3.05 & 1.83 & 90.03 & & \\
\hline & & 9.14 & 1.52 & 0.84 & 11.68 & & \\
\hline & & 16.46 & 2.13 & 1.22 & 42.81 & 144.52 & 50952 \\
\hline \multirow{2}{*}{8} & & & & & & & \\
\hline & 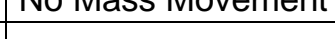 & & & & & & \\
\hline \multirow[t]{8}{*}{11} & Debris Slide & 15.24 & 5.49 & 1.22 & 101.93 & & \\
\hline & & 9.14 & 4.57 & 0.84 & 35.04 & & \\
\hline & & 7.62 & 4.88 & 0.91 & 33.98 & & \\
\hline & Rock fall (5) & 2.13 & 1.07 & 0.76 & 1.73 & & \\
\hline & & 1.52 & 1.07 & 0.76 & 1.24 & & \\
\hline & & 1.22 & 1.07 & 1.07 & 1.39 & & \\
\hline & & 1.07 & 0.84 & 0.61 & 0.55 & & \\
\hline & & 0.91 & 0.76 & 0.46 & 0.32 & 176.16 & 87648 \\
\hline & & & & & & & \\
\hline \multirow[t]{3}{*}{16} & Rock fall (3) & 1.68 & 1.22 & 0.46 & 0.93 & & \\
\hline & & 0.91 & 0.76 & 0.30 & 0.21 & & \\
\hline & & 1.98 & 1.07 & 1.37 & 2.90 & 4.05 & 86196 \\
\hline & & & & & & & \\
\hline \multirow[t]{7}{*}{17} & Rock fall (4) & 0.91 & 0.61 & 0.46 & 0.25 & & \\
\hline & & 1.52 & 1.52 & 0.91 & 2.12 & & \\
\hline & & 1.52 & 0.61 & 0.61 & 0.57 & & \\
\hline & & 1.22 & 1.07 & 0.91 & 1.19 & & \\
\hline & Debris Slide & 4.57 & 1.22 & 0.30 & 1.70 & & \\
\hline & Debris Slide & 10.67 & 9.14 & 0.76 & 74.32 & & \\
\hline & Debris Slide & 3.66 & 3.66 & 1.52 & 20.39 & 100.54 & 52800 \\
\hline \multirow{3}{*}{20} & & & & & & & \\
\hline & Debris Slide & 45.72 & 5.18 & 0.61 & 144.39 & & \\
\hline & Rock fall (1) & 1.22 & 0.76 & 0.91 & 0.85 & 145.24 & 63360 \\
\hline \multirow{7}{*}{26} & Debris Slide & 4.57 & 3.05 & 0.88 & 12.32 & & \\
\hline & Rock fall (3) & 1.52 & 0.91 & 0.76 & 1.06 & & \\
\hline & & 1.22 & 1.07 & 0.76 & 0.99 & & \\
\hline & & 2.13 & 1.52 & 0.91 & 2.97 & 17.34 & 50028 \\
\hline & \multicolumn{4}{|l|}{ Total } & & 58785 & 390984 \\
\hline & \multicolumn{4}{|c|}{ Number of Years of Abandonment } & & & 21 \\
\hline & \multicolumn{4}{|c|}{ Rate of Denudation in $\mathrm{m} /$ million years } & & & 71.60 \\
\hline
\end{tabular}

Appendix 8: Data for deudation rates due to mass movement for the

Hinton Formation Lithology long the New River from Glade Creek to 4.56

km upstream. 